\title{
Identification of candidate biomarkers and therapeutic agents for heart failure by bioinformatics analysis
}

Basavaraj Vastrad ${ }^{1}$, Anandkumar Tengli ${ }^{2}$, Chanabasayya Vastrad $*^{3}$

1. Department of Biochemistry, Basaveshwar College of Pharmacy, Gadag, Karnataka 582103, India.

2. Department of Pharmaceutical Chemistry, JSS College of Pharmacy, Mysuru and JSS Academy of Higher Education \& Research, Mysuru, Karnataka, 570015, India

3. Biostatistics and Bioinformatics, Chanabasava Nilaya, Bharthinagar, Dharwad 580001, Karnataka, India.

* Chanabasayya Vastrad

channu.vastrad@gmail.com

Ph: +919480073398

Chanabasava Nilaya, Bharthinagar,

Dharwad 580001 , Karanataka, India 


\section{Abstract}

Heart failure (HF) is a heterogeneous clinical syndrome and affects millions of people all over the world. HF occurs when the cardiac overload and injury, which is a worldwide complaint. The aim of this study was to screen and verify hub genes involved in developmental HF as well as to explore active drug molecules. The expression profiling by high throughput sequencing of GSE141910 dataset was downloaded from the Gene Expression Omnibus (GEO) database, which contained 366 samples, including 200 heart failure samples and 166 non heart failure samples. The raw data was integrated to find differentially expressed genes (DEGs) and were further analyzed with bioinformatics analysis. Gene ontology (GO) and REACTOME enrichment analyses were performed via ToppGene; protein-protein interaction (PPI) networks of the DEGs was constructed based on data from the HiPPIE interactome database; modules analysis was performed; target gene - miRNA regulatory network and target gene - TF regulatory network were constructed and analyzed; hub genes were validated; molecular docking studies was performed. A total of 881 DEGs, including 442 up regulated genes and 439 down regulated genes were observed. Most of the DEGs were significantly enriched in biological adhesion, extracellular matrix, signaling receptor binding, secretion, intrinsic component of plasma membrane, signaling receptor activity, extracellular matrix organization and neutrophil degranulation. The top hub genes ESR1, PYHIN1, PPP2R2B, LCK, TP63, PCLAF, CFTR, TK1, ECT2 and FKBP5 were identified from the PPI network. Module analysis revealed that HF was associated with adaptive immune system and neutrophil degranulation. The target genes, miRNAs and TFs were identified from the target gene - miRNA regulatory network and target gene - TF regulatory network. Furthermore, receiver operating characteristic (ROC) curve analysis and RT-PCR analysis revealed that ESR1, PYHIN1, PPP2R2B, LCK, TP63, PCLAF, CFTR, TK1, ECT2 and FKBP5 might serve as prognostic, diagnostic biomarkers and therapeutic target for HF. The predicted targets of these active molecules were then confirmed. The current investigation identified a series of key genes and pathways that might be involved in the progression of $\mathrm{HF}$, providing a new understanding of the underlying molecular mechanisms of HF.

Keywords: heart failure; differentially expressed genes; molecular docking; enrichment analysis; prognosis 


\section{Introduction}

Heart failure (HF) is a cardiovascular disease characterized by tachycardia, tachypnoea, pulmonary rales, pleural effusion, raised jugular venous pressure, peripheral oedema and hepatomegaly [1]. Morbidity and mortality linked with HF is a prevalent worldwide health problem holding a universal position as the leading cause of death [2]. The numbers of cases of HF are rising globally and it has become a key health issue. According to a survey, the prevalence HF is expected to exceed $50 \%$ of the global population [3]. Research suggests that modification in multiple genes and signaling pathways are associated in controlling the advancement of HF. However, a lack of investigation on the precise molecular mechanisms of HF development limits the treatment efficacy of the disease at present.

Previous study showed that HF was related to the expression of MECP2 [4] and RBM20 [5]. Toll-Like receptor signaling pathway [6] and activin type II receptor signaling pathway [7] were liable for progression of HF. More investigations are required to focus on treatments that enhance the outcome of patients with HF, to strictly make the diagnosis of the disease based on screening of biomarkers. These investigations can upgrade prognosis of patients by lowering the risk of advancement of $\mathrm{HF}$ and related complications. So it is essential to recognize the mechanism and find biomarkers with a good specificity and sensitivity.

The recent high-throughput RNA sequencing data has been widely employed to screen the differentially expressed genes (DEGs) between normal samples and HF samples in human beings, which makes it accessible for us to further explore the entire molecular alterations in $\mathrm{HF}$ at multiple levels involving DNA, RNA, proteins, epigenetic alterations, and metabolism [8]. However, there still exist obstacles to put these RNA seq data in application in clinic for the reason that the number of DEGs found by expression profiling by high throughput sequencing were massive and the statistical analyses were also too sophisticated [9-10]

In this study, first, we had chosen dataset GSE141910 from Gene Expression Omnibus (GEO) (http:// www.ncbi.nlm.nih.gov/geo/) [11]. Second, we applied for 
limma tool in R software to obtain the differentially expressed genes (DEGs) in this dataset. Third, the ToppGene was used to analyze these DEGs including molecular function (MF), cellular component (CC), biological process (BP) and REACTOME pathways. Fourth, we established protein-protein interaction (PPI) network and then applied Cytotype PEWCC1 for module analysis of the DEGs which would identify some hub genes. Fifth, we established target gene - miRNA regulatory network and target gene - TF regulatory network. In addition, we further validated the hub genes by receiver operating characteristic (ROC) curve analysis and RT-PCR analysis. Finally, we performed molecular docking studies for over expressed hub genes. Results from the present investigation might provide new vision into potential prognostic and therapeutic targets for HF.

\section{Materials and Methods}

\section{Data resource}

Expression profiling by high throughput sequencing with series number GSE141910 based on platform GPL16791 was downloaded from the GEO database. The dataset of GSE141910 contained 200 heart failure samples and 166 non heart failure samples. It was downloaded from the GEO database in NCBI based on the platform of GPL16791 Illumina HiSeq 2500 (Homo sapiens).

\section{Identification of DEGs in HF}

DEGs of dataset GSE141910 between HF groups and non heart failure groups were respectively analyzed using the limma package in $\mathrm{R}[12]$. Fold changes (FCs) in the expression of individual genes were calculated and DEGs with $\mathrm{P}<0.05, \mid \log$ $\mathrm{FC} \mid>1.158$ for up regulated genes and $|\log \mathrm{FC}|<-0.83$ for down regulated genes were considered to be significant. Hierarchical clustering and visualization were used by Heat-map package of R.

\section{Functional enrichment analysis}

Gene Ontology (GO) analysis and REACTOME pathway analysis were performed to determine the functions of DEGs using the ToppGene (ToppFun) (https://toppgene.cchmc.org/enrichment.jsp) [13] GO terms (http://geneontology.org/) [14] included biological processes (BP), cellular components (CC) and molecular functions (MF) of genomic products. 
REACTOME (https://reactome.org/) [15] analyzes pathways of important gene products. ToppGene is a bioinformatics database for analyzing the functional interpretation of lists of proteins and genes. The cutoff value was set to $\mathrm{P}<0.05$.

\section{Protein-protein interaction network construction and module screening}

PPI networks are used to establish all protein coding genes into a massive biological network that serves an advance compassionate of the functional system of the proteome [16]. The HiPPIE interactome (https://cbdm.uni-mainz.de/hippie/) [17] database furnish information regarding predicted and experimental interactions of proteins. In the current investigation, the DEGs were mapped into the HiPPIE interactome database to find significant protein pairs with a combined score of $>0.4$. The PPI network was subsequently constructed using Cytoscape software, version 3.8.2 (www.cytoscape.org) [18]. The nodes with a higher node degree [19], higher betweenness centrality [20], higher stress centrality [21] and higher closeness centrality [22] were considered as hub genes. Additionally, cluster analysis for identifying significant function modules with a degree cutoff $>2$ in the PPI network was performed using the PEWCC1 (http://apps.cytoscape.org/apps/PEWCC1) [23] in Cytoscape.

\section{Target gene - miRNA regulatory network construction}

The miRNet database (https://www.mirnet.ca/) [24] contains information on miRNA and the regulated genes. Using information collected from the miRNet database, hub genes were matched with their associated miRNA. The target gene miRNA regulatory network then was constructed using Cytoscape software.

\section{Target gene - TF regulatory network construction}

The NetworkAnalyst database (https://www.networkanalyst.ca/) [25] contains information on TF and the regulated genes. Using information collected from the NetworkAnalyst database, hub genes were matched with their associated TF. The target gene - TF regulatory network then was constructed using Cytoscape software.

\section{Receiver operating characteristic (ROC) curve analysis}


Then ROC curve analysis was implement to classify the sensitivity and specificity of the hub genes for HF diagnosis and we investigated how large the area under the curve (AUC) was by using the statistical package pROC in R software [26].

\section{RT-PCR analysis}

Total RNA was isolated from H9c2 (ATCC® CRL-1446) and VH2 (ATCC® CCL-140) using the TRI Reagent ${ }^{\circledR}$ (Sigma, USA). cDNA was synthesized using $2.0 \mu \mathrm{g}$ of total RNA with the Reverse transcription cDNA kit (Thermo Fisher Scientific, Waltham, MA, USA). The 7 Flex real-time PCR system (Thermo Fisher Scientific, Waltham, MA, USA) was employed to detect the relative mRNA expression. The relative expression levels were determined by the $2-\Delta \Delta \mathrm{Ct}$ method and normalized to internal control beta-actin [27]. All RT-PCR reactions were performed in triplicate. The primers used to explore mRNA expression of ten hub genes were listed in Table 1.

\section{Identification of Candidate Small Molecules}

SYBYL-X 2.0 perpetual drug design software has been used for surflex-docking studies of the designed novel molecules and the standard on over expressed genes of PDB protein. Using ChemDraw Software, all designed molecules and standards were sketched, imported and saved using open babel free software in sdf. template. The protein of over expressed genes of ESR1, LCK, PPP2R2B, TP63 and their cocrystallised protein of PDB code 4PXM, 1KSW, 2HV7, 3VD8 and 6RU6 were extracted from Protein Data Bank [28-31]. Optimizations of the designed molecules were performed by standard process by applying Gasteiger Huckel (GH) charges together with the TRIPOS force field. In addition, energy minimization was achieved using MMFF94s and MMFF94 algorithm methods. The preparation of the protein was done after protein incorporation. The co-crystallized ligand and all water molecules have been eliminated from the crystal structure; more hydrogen's were added and the side chain was set, TRIPOS force field was used for the minimization of structure. The interaction efficiency of the compounds with the receptor was expressed in kcal / mol units by the Surflex-Dock score. The best location was integrated into the molecular region by the interaction between the protein and the ligand. Using Discovery Studio Visualizer, the visualisation of ligand interaction with receptor is performed. 


\section{Results}

\section{Identification of DEGs in HF}

We identified 881 DEGs in the GSE141910 dataset using the limma package in R. Based on the limma analysis, using the adj $\mathrm{P}$ val $<0.05,|\log \mathrm{FC}|>1.158$ for up regulated genes and $|\log \mathrm{FC}|<-0.83$ for down regulated genes criteria, a total of 881 DEGs were identified, consisting of 442 genes were up regulated and 439 genes were down regulated. The DEGs are listed in Table 2. The volcano plot for DEGs is illustrated in Fig. 1. Fig. 2 is the hierarchical clustering heat-map.

\section{Functional enrichment analysis}

Results of GO analysis showed that the up regulated genes were significantly enriched in $\mathrm{BP}, \mathrm{CC}$, and $\mathrm{MF}$, including biological adhesion, regulation of immune system process, extracellular matrix, cell surface, signaling receptor binding and molecular function regulator (Table 3); the down regulated genes were significantly enriched in $\mathrm{BP}, \mathrm{CC}$, and $\mathrm{MF}$, including secretion, defense response, intrinsic component of plasma membrane, whole membrane, signaling receptor activity and molecular transducer activity (Table 3). Pathway analysis showed that the up regulated genes were significantly enriched in extracellular matrix organization and immunoregulatory interactions between a lymphoid and a nonlymphoid cell (Table 4); the down regulated genes were significantly enriched in neutrophil degranulation and SLC-mediated transmembrane transport (Table 4).

\section{Protein-protein interaction (PPI) network and module analysis}

Based on the HiPPIE interactome database, the PPI network for the DEGs (including 6541 nodes and 13909 edges) was constructed (Fig. 3A). Up regulated gene with higher node degree, higher betweenness centrality, higher stress centrality and higher closeness centrality were as follows: ESR1, PYHIN1, PPP2R2B, LCK, TP63 and so on. Down regulated genes had higher node degree, higher betweenness centrality, higher stress centrality and higher closeness centrality were as follows PCLAF, CFTR, TK1, ECT2, FKBP5 and so on. The node degree, betweenness centrality, stress centrality and closeness centrality are listed in Table 5. 
Additionally, two significant modules, including module 1 (10 nodes and 24 edges) and module 2 ( 5 nodes and 10 edges) (Fig. 3B) and module 3 (55 nodes and 115 edges), were acquired by PEWCC1 plug-in (Fig. 3C). Furthermore, GO terms and REACTOME pathways were significantly enriched by module 1 , including adaptive immune system, immunoregulatory interactions between a lymphoid and a non-lymphoid cell, hemostasis, biological adhesion and regulation of immune system process. Meanwhile, the nodes in module 2 were significantly enriched in GO terms and REACTOME pathways, including neutrophil degranulation and secretion.

\section{Target gene - miRNA regulatory network construction}

Associations between 2063 miRNAs and their 319 target genes were collected from the target gene - miRNA regulatory network (Fig. 4). MiRNAs of hsa-mir4533, hsa-mir-548ac, hsa-mir-548i, hsa-mir-5585-3p, hsa-mir-6750-3p, hsa-mir200c-3p, hsa-mir-1273g-3p, hsa-mir-1244, hsa-mir-4789-3p and hsa-mir-766-3p, which exhibited a high degree of interaction, were selected from this network. Furthermore, the results also showed that FSCN1 was the target of hsa-mir-4533, ESR1 was the target of hsa-mir-548ac, TMEM30B was the target of hsa-mir-548i, SCN2B was the target of hsa-mir-5585-3p, CENPA was the target of hsa-mir6750-3p, FKBP5 was the target of hsa-mir-200c-3p, PCLAF was the target of hsamir-1273g-3p, CEP55 was the target of hsa-mir-1244, ATP2A2 was the target of hsa-mir-4789-3p and TK1 was the target of hsa-mir-766-3p, and are listed in Table 6.

\section{Target gene - TF regulatory network construction}

Associations between $330 \mathrm{TFs}$ and their 247 target genes were collected from the target gene - TF regulatory network (Fig. 5). TFs of ESRRA, RERE, HMG20B, THRAP3, ATF1, MXD3, ARID4B, CBFB, TAF7 and CREM, which exhibited a high degree of interaction, were selected from this network. Furthermore, the results also showed that FSCN1 was the target of ESRRA, APOA1 was the target of RERE, COL1A1 was the target of HMG20B, HBB was the target of THRAP3, LCK was the target of ATF1, SOCS3 was the target of MXD3, BCL6 was the target of ARID4B, FKBP5 was the target of CBFB, ANLN was the target of TAF7 and ATP2A2 was the target of CREM, and are listed in Table 6. 


\section{Receiver operating characteristic (ROC) curve analysis}

First of all, we performed the ROC curve analysis among 10 hub genes based on the GSE141910. The results showed that ESR1, PYHIN1, PPP2R2B, LCK, TP63, PCLAF, CFTR, TK1, ECT2 and FKBP5 achieved an AUC value of $\square>\square 0.7$, demonstrating that these ten genes have high sensitivity and specificity for HF, suggesting they can be served as biomarkers for the diagnosis of HF (Fig. 6).

\section{RT-PCR analysis}

RT-PCR was used to validate the hub genes between normal and HF cell lines. The results suggested that the mRNA expression level of ESR1, PYHIN1, PPP2R2B, LCK and TP63 were significantly increased in HF compared with that in normal, while PCLAF, CFTR, TK1, ECT2 and FKBP5 were significantly decreased in HF compared with that in normal and are shown in Fig. 7.

\section{Identification of Candidate Small Molecules}

In the present study docking simulations are performed to spot the active site and foremost interactions accountable for complex stability with the receptor binding sites. In heart failure recognized over expressed genes and their proteins of x-ray crystallographic structure are chosen from PDB for docking studies. Most generally, medications containing benzothiadiazine ring hydrochlorothiazide are used in heart failure either alone or in conjunction with other drugs, based on this the molecules containing heterocyclic ring of benzothiadiazine are designed and hydrochlorothiazide is uses as a reference standard. Docking experiments using Sybyl-X 2.1.1. drug design perpetual software were used on the designed molecules. Docking studies were performed in order to understand the biding interaction of standard hydrochlorothiazide and designed molecules on over expressed protein. The X- RAY crystallographic structure of one proteins from each over expressed genes of ESR1, LCK, PPP2R2B, PYHIN1, TP63 and their cocrystallised protein of PDB code 4PXM, 1KSW, 2HV7, 3VD8 and 6RU6 respectively were selected for the docking studies to identify and predict the potential molecule based on the binding score with the protein and successful in heart failure. For the docking tests, a total of 34 molecules were built and the molecule with binding score greater than 5 is believed to be good. The designed molecules obtained docking score of 5 to 7 were HIM10, HTZ5, HIM6, HTZ31, 
HIM3, HIM14, HIM1, HIM7 and HIM11, HIM16, HTZ9, HIM17, HIM12, HTZ12, HIM6, HTZ7, HIM10, HTZ3 and HIM8, HTZ9, HIM6, HIM4, HIM13, HTZ16, HIM9, HIM7, HTZ5, HIM16, HTZ7, HIM10, HIM5, HIM12, HIM15, HTZ12, HIM3, HIM14 and HIM14, HIM6, HIM17, HTZ7, HIM10, HIM1, HTZ9, HIM3, HIM16, HIM15, HIM8, HIM9, HIM7, HTZ10, HTZ3, HTZ5, HTZ1, HIM13, HTZ4, HIM11, HTZ12, HTZ14, HIM2 and HIM7, HTZ13, HTZ5, HIM15, HIM12, HIM6, HTZ11, HIM14, HTZ9, HIM11, HIM13, HIM9, HIM8, HIM10, HIM1, HIM5, HIM4, HTZ12, HIM2, HIM17, HIM3, HTZ1, HTZ8, HIM3, HTZ14, HTZ3 with proteins 4PXM and, 1KSW and 2HV7 and 3VD8 and 6RUR respectively (Fig. 8). The molecules obtained binding score of less than 5 were HTZ13, HTZ12, HTZ10, HIM3, HIM15, HIM16, HIM13, HIM8, HTZ16, HIM2, HIM4, HIM17, HTZ17, HIM11, HTZ5, HTZ3, HIM9, HTZ15, HTZ5, HTZ9, HTZ11, HIM5, HTZ8 and HTZ14, HIM14, HTZ13, HIM13, HTZ16, HIM2, HIM3, HTZ10, HIM7, HIM1, HTZ1, HTZ4, HIM8, HIM5, HTZ2, HIM9, HTZ5, HTZ15, HTZ3, HIM4, HIM15, HTZ17, HTZ8, HTZ11 and HTZ14, HIM2, HIM1, HTZ11, HIM17, HTZ13, HTZ4, HTZ2, HIM3, HTZ15, HTZ8, HTZ17, HTZ1, HTZ3 and HTZ8, HIM4, HTZ16, HTZ15, HIM5, HTZ11, HTZ13, HIM3, HTZ17, HTZ2 and HTZ7, HTZ4, HTZ2, HTZ17, HTZ15 with proteins 4PXM and, $1 \mathrm{KSW}$ and $2 \mathrm{HV} 7$ and 3VD8 and 6RUR respectively. The molecules obtained very less binding score are HTZ1, HIM12, HTZ2, HTZ4 with protein 4PXM and the standard hydrochlorothiazide (HTZ) obtained less binding score with all proteins, the values are depicted in Table 7.

\section{Discussion}

$\mathrm{HF}$ is the most prevalent form of cardiovascular disease among the elderly. A complete studies of HF, comprising pathogenic factors, pathological processes, clinical manifestations, early clinical diagnosis, clinical prevention, and drug therapy targets urgency to be consistently analyzed. In the present investigation, bioinformatics analysis was engaged to explore HF biomarkers and the pathological processes in myocardial tissues, acquired from HF groups and non heart failure groups. We analyzed GSE141910 expression profiling by high throughput sequencing obtained 881 different genes between HF groups and non heart failure groups, 442 up regulated and 439 down regulated genes. HBA2 and HBA1 have a key role in hypertension [32], but these genes might be linked with 
development HF. SFRP4 was linked with progression of myocardial ischemia [33]. Emmens et al. [34] and Broch et al. [35] found that PENK (proenkephalin) and IL1RL1 were up regulated in HF. ALOX15B has lipid accumulation and inflammation activity and is highly expressed in atherosclerosis [36]. Studies have shown that expression of MYH6 was associated with hypertrophic cardiomyopathy [37].

In functional enrichment analysis, some genes involved with regulation of cardiovascular system processes were enriched in HF. Liu et al. [38], Kosugi et al. [39], McMacken et al. [40], Pan and Zhang [41], Li et al. [42] and Jiang et al. [43] presented that expression of HLA-DQA1, KDM5D, UCHL1, SAA1, ARG1 and LYVE1 were associated with progression of cardiomyopathy. Hou et al. [44] and Olesen et al. [45] demonstrated that DACT2 and KCND3 were found to be substantially related to atrial fibrillation. Ge and Concannon [46], Ferjeni et al. [47], Anquetil et al. [48], Glawe et al. [49], Kawabata et al. [50], Li et al. [51], Buraczynska et al. [52], Amini et al. [53], Yang et al. [54], Du Toit et al. [55], Hirose et al. [56], Zhang et al. [57], Griffin et al. [58], Zouidi et al. [59], Trombetta et al. [60], Alharbi et al. [61], Ikarashi et al. [62], Dharmadhikari et al. [63], Sutton et al. [64] and Deng et al. [65] reported that UBASH3A, ZAP70, IDO1, ITGAL (integrin subunit alpha L). ITGB7, RASGRP1, CNR1, SLC2A1, SLC11A1, GPR84, SSTR5, KCNB1, GLUL (glutamate-ammonia ligase), BANK1, CACNA1E, LGR5, AQP3, SIGLEC7, SSTR2 and DNER (delta/notch like EGF repeat containing) could be an index for diabetes, but these genes might be responsible for progression of HF. Experiments show that expression of FAP (fibroblast activation protein alpha) [66], THBS4 [67], CD27 [68], LEF1 [69], CTHRC1 [70], ESR1 [71], CXCL9 [72], SERPINA3 [73], TRPC4 [74], F13A1 [75], PIK3C2A [76], KCNIP2 [77] and GPR4 [78] contributed to myocardial infarction. MFAP4 [79], ALOX15 [80], COL1A1 [81], APOA1 [82], PDE5A [83], CX3CR1 [84], THY1 [85], GREM1 [86], FMOD (fibromodulin) [87], NPPA (natriuretic peptide A) [88], LTBP2 [89], LUM (lumican) [90], IL34 [91], NRG1 [92], CXCL14 [93], CXCL10 [94], ACE (angiotensin I converting enzyme) [95], CFTR (ystic fibrosis transmembrane conductance regulator) [96], S100A8 [97], S100A9 [97], HP (haptoglobin) [98], AGTR1 [99], ATP2A2 [100], IL10 [101], EDN1 [102], TLR2 [103], MCEMP1 [104], TPO (thyroid peroxidase) [105], CD163 [106], IL18R1 [107], KCNA7 [108] and CALCRL (calcitonin receptor like 
receptor) [109] have an important role in HF. Li et al [110], Deckx et al [111], Ichihara et al [112] and Paik et al [113] showed that the SERPINE2, OGN (osteoglycin), AGTR2 and WNT10B promoted cardiac interstitial fibrosis. Cai et al [114], Mo et al [115], Sun et al [116], Martinelli et al [117], Zhao et al [118], Assimes et al [119] and Piechota et al [120] showed that CCR7, FCN1, ESM1, F8 (coagulation factor VIII), C1QTNF1, ALOX5 and MSR1 were an important target gene for coronary artery disease. STAB2 have been suggested to be associated with venous thromboembolic disease [121]. Genes such as COMP (cartilage oligomeric matrix protein) [122], CHI3L1 [123], PLA2G2A [124], P2RY12 [125], CR1 [126], HPSE (heparanase) [127], PTX3 [128] and SERPINE1 [129] were related to atherosclerosis. CCDC80 [130], CMA1 [131], MDK (midkine) [132], GNA14 [133], SCG2 [134], NPPB (natriuretic peptide B) [135], FGF10 [136], ARNTL (aryl hydrocarbon receptor nuclear translocator like) [137], WNK3 [138], EDNRB (endothelin receptor type B) [139], THBS1 [140], SELE (selectin E) [141], SLC4A7 [142], AQP4 [143] and KCNK3 [144] are thought to be responsible for progression of hypertension, but these genes might to be associated with progression of HF. CNTNAP2 [145], GLI2 [146], DPT (dermatopontin) [147], AEBP1 [148], ITIH5 [149], CXCL11 [150], GDNF (glial cell derived neurotrophic factor) [151], MCHR1 [152], FLT3 [153], ELANE (elastase, neutrophil expressed) [154], OSMR (oncostatin M receptor) [155] and IL15RA [156] are involved in development of obesity, but these genes might be key for progression of HF. CTSG (cathepsin G) is a protein coding gene plays important roles in aortic aneurysms [157]. Evidence from Safa et al. [158], Chen et al. [159], Zhou et al. [160], Hu et al. [161], Lou et al. [162], Zhang et al. [163] and Chen et al. [164] study indicated that the expression of CCL22, CCR1, FPR1, KNG1, CRISPLD2, CD38 and GPRC5A were linked with progression of ischemic heart disease. Li et al. [165] showed that STEAP3 expression can be associated with cardiac hypertrophy progression.

The HiPPIE interactome database was used to construct the PPI network, and modules analysis was performed. We finally screened out up regulated hub genes and down regulated hub genes, including ESR1, PYHIN1, PPP2R2B, LCK, TP63, PCLAF, CD247, CD2, CD5, CD48, CFTR, TK1, ECT2, FKBP5, S100A9 and S100A8 from the PPI network and its modules. TP63 might serve as a potential prognostic factor in cardiomyopathy [166]. The expression of FKBP5 is 
related to the progression of coronary artery disease [167]. CD247 plays a central role in hypertension [168], but this gene might be involved in the HF. PYHIN1, PPP2R2B, LCK (LCK proto-oncogene, Src family tyrosine kinase), PCLAF (PCNA clamp associated factor), TK1, ECT2, CD2, CD5 and CD48 might be the novel biomarker for HF.

The miRNet database and NetworkAnalyst database were used to construct the target gene - miRNA regulatory network and target gene - TF regulatory network. We finally screened out target genes, miRNA, TFs, including FSCN1, ESR1, TMEM30B, SCN2B, CENPA, FKBP5, PCLAF, CEP55, ATP2A2, TK1, APOA1, COL1A1, HBB, LCK, SOCS3, BCL6, ANLN, hsa-mir-4533, hsa-mir548ac, hsa-mir-548i, hsa-mir-5585-3p, hsa-mir-6750-3p, hsa-mir-200c-3p, hsamir-1273g-3p, hsa-mir-1244, hsa-mir-4789-3p, hsa-mir-766-3p, ESRRA, RERE, HMG20B, THRAP3, ATF1, MXD3, ARID4B, CBFB, TAF7 and CREM from the target gene - miRNA regulatory network and target gene - TF regulatory network. SCN2B [169] and SOCS3 [170] are considered as a markers for HF and might be a new therapeutic target. BCL6 levels are correlated with disease severity in patients with atherosclerosis [171]. A previous study showed that hsa-mir-1273g$3 p$ [172], hsa-mir-4789-3p [173] and ATF1 [174] could involved in hypertension, but these markers might be responsible for progression of HF. hsa-miR-518f, was demonstrated to be associated with cardiomyopathy [175]. An evidence demonstrating a role for ESRRA (estrogen related receptor alpha) [176] and THRAP3 [177] in diabetes, but these genes might be liable for development of HF. FSCN1, TMEM30B, CENPA (centromere protein A), CEP55, HBB (hemoglobin subunit beta), ANLN (anillin actin binding protein), hsa-mir-4533, hsa-mir-548ac, hsa-mir-548i, hsa-mir-5585-3p, hsa-mir-6750-3p, hsa-mir-200c-3p, hsa-mir-1244, RERE(arginine-glutamic acid dipeptide repeats), HMG20B, MXD3, ARID4B, CBFB (core-binding factor subunit beta), TAF7 and CREM (cAMP response element modulator) might be the novel biomarker for HF.

The molecules HIM6, HIM10 obtained good binding score of more 5 to 6.999 with all proteins and the molecules HIM11, HIM12, HIM14, HTZ9, HTZ10 and HTZ12 obtained binding score above 5 and less than 9 with PDB protein code of 2HV7, 3VD8 and 6RUR respectively. The molecule HIM11 obtained highest binding score of 8.678 with $2 \mathrm{HV7}$ and its interaction with amino acids are molecule HIM11 (Fig. 9) has obtained with a high binding score with PDB protein 
2HV7, the interactions of molecule is the $\mathrm{C} 6$ side chin acyl carbonyl $\mathrm{C}=\mathrm{O}$ formed hydrogen bond interaction with amino acid GLN-207 with bond length $1.92 \mathrm{~A}^{\circ}$ and $3^{\prime} \mathrm{N}-\mathrm{H}$ group of imidazole ring formed hydrogen bond interaction with VAL305 with bond length $2.36 \mathrm{~A}^{\circ}$ respectively. It also formed other interactions of carbon hydrogen bond of $-\mathrm{CH}_{3}$ group of carboxylate at C6 with PRO-304 and amide-pi stacked and pi-pi stacked interaction of electrons of aromatic ring A with ALA-204 and ring C with HIS-155 and HIS-308. Molecule formed pi-alkyl interaction of ring B with PRO-304 and all interactions with amino acids and bond length are depicted by 3D and 2D figures (Fig.10 and Fig.11).

\section{Conclusions}

The present study provided an extensive bioinformatics analysis of DEGs and revealed a series of targets and pathways, which may affect the progression of HF, for future investigation. And many of them, such as ESR1, PYHIN1, PPP2R2B, LCK, TP63, PCLAF, CFTR, TK1, ECT2 and FKBP5, might be key genes related to HF. The current investigation identified active molecules that might represent novel treatments for $\mathrm{HF}$ and may reduce the range of potential drugs for treating HF. These findings add to significant insights into the diagnosis and treatment of HF.

\section{Acknowledgement}

I thank Michael Patrick Morley, Perelman School of Medicine at the University of Pennsylvania, Penn Cardiovascular Institute, Philadelphia, USA, very much, the author who deposited their profiling by high throughput sequencing dataset GSE141910, into the public GEO database.

\section{Conflict of interest}

The authors declare that they have no conflict of interest.

\section{Ethical approval}

This article does not contain any studies with human participants or animals performed by any of the authors.

\section{Informed consent}


No informed consent because this study does not contain human or animals participants.

\section{Availability of data and materials}

The datasets supporting the conclusions of this article are available in the GEO (Gene Expression Omnibus) (https://www.ncbi.nlm.nih.gov/geo/) repository. [(GSE141910) (https://www.ncbi.nlm.nih.gov/geo/query/acc.cgi?acc=GSE141910]

\section{Consent for publication}

Not applicable.

\section{Competing interests}

The authors declare that they have no competing interests.

\section{Author Contributions}

B. V - Writing original draft, and review and editing
A. T - Formal analysis and validation
C. V - Software and investigation

\section{Authors}

Basavaraj Vastrad

Anandkumar Tengli

Chanabasayya Vastrad
ORCID ID: 0000-0003-2202-7637

ORCID ID: 0000-0001-8076-928X

ORCID ID: 0000-0003-3615-4450

\section{References}

1. Xanthopoulos A, Triposkiadis F, Starling RC. Heart failure with preserved ejection fraction: Classification based upon phenotype is essential for diagnosis and treatment. Trends Cardiovasc Med. 2018;28(6):392-400. doi:10.1016/j.tcm.2018.01.001

2. Mosterd A, Hoes AW. Clinical epidemiology of heart failure. Heart. 2007;93(9):1137-1146. doi:10.1136/hrt.2003.025270 
3. Roger VL, Weston SA, Redfield MM, Hellermann-Homan JP, Killian J, Yawn BP, Jacobsen SJ. Trends in heart failure incidence and survival in a community-based population. JAMA. 2004;292(3):344-350. doi:10.1001/jama.292.3.344

4. Wang C, Wang F, Cao Q, Li Z, Huang L, Chen S. The Effect of Mecp2 on Heart Failure. Cell Physiol Biochem. 2018;47(6):2380-2387. doi:10.1159/000491610

5. Ma J, Lu L, Guo W, Ren J, Yang J. Emerging Role for RBM20 and its Splicing Substrates in Cardiac Function and Heart Failure. Curr Pharm Des. 2016;22(31):4744-4751. doi:10.2174/1381612822666160701145322

6. Roh JD, Hobson R, Chaudhari V, Quintero P, Yeri A, Benson M, Xiao C, Zlotoff D, Bezzerides V, Houstis N, et al. Activin type II receptor signaling in cardiac aging and heart failure. Sci Transl Med. 2019;11(482):eaau8680. doi:10.1126/scitranslmed.aau8680

7. Yu L, Feng Z. The Role of Toll-Like Receptor Signaling in the Progression of Heart Failure. Mediators Inflamm. 2018;2018:9874109. doi:10.1155/2018/9874109

8. Li X, Li B, Jiang H. Identification of time $\square$ series differentially expressed genes and pathways associated with heart failure post $\square$ myocardial infarction using integrated bioinformatics analysis. Mol Med Rep. 2019;19(6):52815290. doi:10.3892/mmr.2019.10190

9. Liu Y, Morley M, Brandimarto J, Hannenhalli S, Hu Y, Ashley EA, Tang WH, Moravec CS, Margulies KB, Cappola TP, et al. RNA-Seq identifies novel myocardial gene expression signatures of heart failure. Genomics. 2015;105(2):83-89. doi:10.1016/j.ygeno.2014.12.002

10.Schiano C, Costa V, Aprile M, Grimaldi V, Maiello C, Esposito R, Soricelli A, Colantuoni V, Donatelli F, Ciccodicola A, et al. Heart failure: Pilot transcriptomic analysis of cardiac tissue by RNA-sequencing. Cardiol J. 2017;24(5):539-553. doi:10.5603/CJ.a2017.0052

11.Clough E, Barrett T. The Gene Expression Omnibus Database. Methods Mol Biol. 2016;1418:93-110. doi:10.1007/978-1-4939-3578-9_5

12.Ritchie ME, Phipson B, Wu D, Hu Y, Law CW, Shi W, Smyth GK. limma powers differential expression analyses for RNA-sequencing and microarray studies. Nucleic Acids Res. 2015;43(7):e47. doi:10.1093/nar/gkv007 
13.Thomas PD. The Gene Ontology and the Meaning of Biological Function. Methods Mol Biol. 2017;1446:15 $\square 24$. doi:10.1007/978-1-4939-3743-1_2

14. Chen J, Bardes EE, Aronow BJ, Jegga AG. ToppGene Suite for gene list enrichment analysis and candidate gene prioritization. Nucleic Acids Res. 2009;37(Web Server issue):W305-W311. doi:10.1093/nar/gkp427

15.Fabregat A, Jupe S, Matthews L, Sidiropoulos K, Gillespie M, Garapati P, Haw R, Jassal B, Korninger F, May B et al The Reactome Pathway Knowledgebase. Nucleic Acids Res. 2018;46(D1):D649-D655. doi:10.1093/nar/gkx1132

16.Kong J, Li L, Zhimin L, Yan J, Ji D, Chen Y, Yuanyuan W, Chen X, Shao $\mathrm{H}$, Wang $\mathrm{J}$, et al. Potential protein biomarkers for systemic lupus erythematosus determined by bioinformatics analysis. Comput Biol Chem. 2019;83:107135. doi:10.1016/j.compbiolchem.2019.107135

17. Alanis-Lobato G, Andrade-Navarro MA, Schaefer MH. HIPPIE v2.0: enhancing meaningfulness and reliability of protein-protein interaction networks. Nucleic Acids Res. 2017;45(D1):D408-D414. doi:10.1093/nar/gkw985

18. Shannon P, Markiel A, Ozier O, Baliga NS, Wang JT, Ramage D, Amin N, Schwikowski B, Ideker T Cytoscape: a software environment for integrated models of biomolecular interaction networks. Genome Res 2003;13(11):2498-2504. doi:10.1101/gr.1239303

19.Przulj N, Wigle DA, Jurisica I. Functional topology in a network of protein interactions. Bioinformatics. 2004;20(3):340-348. doi:10.1093/bioinformatics/btg415

20.Nguyen TP, Liu WC, Jordán F. Inferring pleiotropy by network analysis: linked diseases in the human PPI network. BMC Syst Biol. 2011;5:179. doi:10.1186/1752-0509-5-179

21.Shi Z, Zhang B. Fast network centrality analysis using GPUs. BMC Bioinformatics. 2011;12:149. doi:10.1186/1471-2105-12-149

22.Fadhal E, Gamieldien J, Mwambene EC. Protein interaction networks as metric spaces: a novel perspective on distribution of hubs. BMC Syst Biol. 2014;8:6. doi:10.1186/1752-0509-8-6

23.Zaki N, Efimov D, Berengueres J. Protein complex detection using interaction reliability assessment and weighted clustering coefficient. BMC Bioinformatics. 2013;14:163. doi:10.1186/1471-2105-14 
24.Fan Y, Xia J (2018) miRNet-Functional Analysis and Visual Exploration of miRNA-Target Interactions in a Network Context. Methods Mol Biol 1819:215-233. doi:10.1007/978-1-4939-8618-7_10

25.Zhou G, Soufan O, Ewald J, Hancock REW, Basu N, Xia J (2019) NetworkAnalyst 3.0: a visual analytics platform for comprehensive gene expression profiling and meta-analysis. Nucleic Acids Res 47:W234-W241. doi:10.1093/nar/gkz240

26. Robin X, Turck N, Hainard A, Tiberti N, Lisacek F, Sanchez JC, Müller M. pROC: an open-source package for $\mathrm{R}$ and $\mathrm{S}+$ to analyze and compare ROC curves. BMC Bioinformatics 2011;12:77. doi:10.1186/1471-2105-12-77

27.Livak KJ, Schmittgen TD. Analysis of relative gene expression data using real-time quantitative PCR and the 2(-Delta Delta C(T)) Method. Methods. 2001;25(4):402-408. doi:10.1006/meth.2001.1262

28.Liao C, Sitzmann M, Pugliese A, Nicklaus MC. Software and resources for computational medicinal chemistry. Future Med Chem. 2011;3(8):10571085. doi:10.4155/fmc. 11.63

29.O'Boyle NM, Banck M, James CA, Morley C, Vandermeersch T, Hutchison GR. Open Babel: An open chemical toolbox. J Cheminform. 2011;3:33. doi:10.1186/1758-2946-3-33

30. Okawa T, Aramaki Y, Yamamoto M, Kobayashi T, Fukumoto S, Toyoda Y, Henta T, Hata A, Ikeda S, Kaneko M, et al. Design, Synthesis, and Evaluation of the Highly Selective and Potent G-Protein-Coupled Receptor Kinase 2 (GRK2) Inhibitor for the Potential Treatment of Heart Failure. J Med Chem. 2017;60(16):6942-6990. doi:10.1021/acs.jmedchem.7b00443

31.Liu J, Liu Y, Yu H, Zhang Y, Hsu AC, Zhang M, Gou Y, Sun W, Wang F, Li P, et al. Design, synthesis and biological evaluation of novel pyxinol derivatives with anti-heart failure activity. Biomed Pharmacother. 2021;133:111050. doi:10.1016/j.biopha.2020.111050

32.Hill QA, Farrar L, Lordan J, Gallienne A, Henderson S. A combination of two novel alpha globin variants $\mathrm{Hb}$ Bridlington (HBA1) and $\mathrm{Hb}$ Taybe (HBA2) resulting in severe hemolysis, pulmonary hypertension, and death. Hematology. 2015;20(1):50-52. doi:10.1179/1607845414Y.0000000164

33.Zeng W, Cao Y, Jiang W, Kang G, Huang J, Xie S. Knockdown of Sfrp4 attenuates apoptosis to protect against myocardial ischemia/reperfusion injury. J Pharmacol Sci. 2019;140(1):14-19. doi:10.1016/j.jphs.2019.04.003 
34.Emmens JE, Ter Maaten JM, Damman K, van Veldhuisen DJ, de Boer RA, Struck J, Bergmann A, Sama IE, Streng KW, Anker SD, et al. Proenkephalin, an Opioid System Surrogate, as a Novel Comprehensive Renal Marker in Heart Failure. Circ Heart Fail. 2019;12(5):e005544. doi:10.1161/CIRCHEARTFAILURE.118.005544

35.Broch K, Ueland T, Yndestad A, Aukrust P, Gullestad L. Heart failure biomarkers: focus on interleukin-1 receptor-like 1-based blood tests. Drugs Today (Barc). 2012;48(7):479-491. doi:10.1358/dot.2012.48.7.1811719

36. Magnusson LU, Lundqvist A, Karlsson MN, Skålén K, Levin M, Wiklund O, Borén J, Hultén LM. Arachidonate 15-lipoxygenase type B knockdown leads to reduced lipid accumulation and inflammation in atherosclerosis. PLoS One. 2012;7(8):e43142. doi:10.1371/journal.pone.0043142

37. Castellana S, Mastroianno S, Palumbo P, Palumbo O, Biagini T, Leone MP, De Luca G, Potenza DR, Amico CM, Mazza T, et al. Sudden death in mild hypertrophic cardiomyopathy with compound DSG2/DSC2/MYH6 mutations: Revisiting phenotype after genetic assessment in a master runner $\begin{array}{llll}\text { athlete. } & \mathrm{J} & \text { Electrocardiol. }\end{array}$ doi:10.1016/j.jelectrocard.2019.01.002

38.Liu W, Li WM, Sun NL. Relationship between HLA-DQA1 polymorphism and genetic susceptibility to idiopathic dilated cardiomyopathy. Chin Med J (Engl). 2004;117(10):1449-1452.

39.Kosugi M, Otani M, Kikkawa Y, Itakura Y, Sakai K, Ito T, Toyoda M, Sekita Y, Kimura T. Mutations of histone demethylase genes encoded by X and $\mathrm{Y}$ chromosomes, $\mathrm{Kdm} 5 \mathrm{c}$ and $\mathrm{Kdm} 5 \mathrm{~d}$, lead to noncompaction cardiomyopathy in mice .. Biochem Biophys Res Commun. 2020;S0006291X(20)30311-9. doi:10.1016/j.bbrc.2020.02.043

40.McMacken G, Lochmüller H, Bansagi B, Pyle A, Lochmüller A, Chinnery $\mathrm{PF}$, et al. Behr syndrome and hypertrophic cardiomyopathy in a family with a novel UCHL1 deletion. J Neurol. 2020;267(12):3643-3649. doi:10.1007/s00415-020-10059-3

41.Pan XY, Zhang ZW. MFGE8, ALB, APOB, APOE, SAA1, A2M, and C3 as Novel Biomarkers for Stress Cardiomyopathy. Cardiovasc Ther. 2020;2020:1615826. doi:10.1155/2020/1615826

42.Li C, Wang L, Li Y, Feng Z, Wang Q, Luo W. Common Variants in the ARG1 Gene Contribute to the Risk of Dilated Cardiomyopathy in the Han 
Chinese Population. Genet Test Mol Biomarkers. 2020;24(9):584-591. doi:10.1089/gtmb.2020.0080

43.Jiang X, Cui J, Yang C, Song Y, Yuan J, Liu S, Hu F, Yang W, Qiao S. Elevated lymphatic vessel density measured by Lyve-1 expression in areas of replacement fibrosis in the ventricular septum of patients with hypertrophic obstructive cardiomyopathy (HOCM). Heart Vessels. 2020;35(1):78-85. doi:10.1007/s00380-019-01463-5

44.Hou J, Huang S, Long Y, Huang J, Yang S, Yao J, Chen G, Yue Y, Liang $\mathrm{M}$, Mei B, et al. DACT2 regulates structural and electrical atrial remodeling in atrial fibrillation. J Thorac Dis. 2020;12(5):2039-2048. doi:10.21037/jtd$19-4206$

45. Olesen MS, Refsgaard L, Holst AG, Larsen AP, Grubb S, Haunsø S, Svendsen JH, Olesen SP, Schmitt N, Calloe K. A novel KCND3 gain-offunction mutation associated with early-onset of persistent lone atrial fibrillation. Cardiovasc Res. 2013;98(3):488-495. doi:10.1093/cvr/cvt028

46.Ge Y, Concannon P. Molecular-genetic characterization of common, noncoding UBASH3A variants associated with type 1 diabetes. Eur J Hum Genet. 2018;26(7):1060-1064. doi:10.1038/s41431-018-0123-5

47.Ferjeni Z, Bouzid D, Fourati H, Stayoussef M, Abida O, Kammoun T, Hachicha M, Penha-Gonçalves C, Masmoudi H. Association of TCR/CD3, PTPN22, CD28 and ZAP70 gene polymorphisms with type 1 diabetes risk in Tunisian population: family based association study. Immunol Lett. 2015;163(1):1-7. doi:10.1016/j.imlet.2014.11.005

48. Anquetil F, Mondanelli G, Gonzalez N, Rodriguez Calvo T, Zapardiel Gonzalo J, Krogvold L, Dahl-Jørgensen K, Van den Eynde B, Orabona C, Grohmann U, et al. Loss of IDO1 Expression From Human Pancreatic $\beta$ Cells Precedes Their Destruction During the Development of Type 1 Diabetes. Diabetes. 2018;67(9):1858-1866. doi:10.2337/db17-1281

49. Glawe JD, Patrick DR, Huang M, Sharp CD, Barlow SC, Kevil CG. Genetic deficiency of Itgb2 or ItgaL prevents autoimmune diabetes through distinctly different mechanisms in NOD/LtJ mice. Diabetes. 2009;58(6):1292-1301. doi:10.2337/db08-0804

50.Kawabata Y, Nishida N, Awata T, Kawasaki E, Imagawa A, Shimada A, Osawa H, Tanaka S, Takahashi K, Nagata M, et al. Genome-Wide Association Study Confirming a Strong Effect of HLA and Identifying 
Variants in CSAD/lnc-ITGB7-1 on Chromosome 12q13.13 Associated With Susceptibility to Fulminant Type 1 Diabetes. Diabetes. 2019;68(3):665-675. doi: $10.2337 / \mathrm{db} 18-0314$

51.Li JY, Tao F, Wu XX, Tan YZ, He L, Lu H. Common RASGRP1 Gene Variants That Confer Risk of Type 2 Diabetes. Genet Test Mol Biomarkers. 2015;19(8):439-443. doi:10.1089/gtmb.2015.0005

52.Buraczynska M, Wacinski P, Zukowski P, Dragan M, Ksiazek A. Common polymorphism in the cannabinoid type 1 receptor gene (CNR1) is associated with microvascular complications in type 2 diabetes. $\mathrm{J}$ Diabetes Complications. 2014;28(1):35-39. doi:10.1016/j.jdiacomp.2013.08.005

53. Amini S, Javanmardi M, Mokarizadeh A, Maroofi F, Jalali C, Azadi NA, Mohammadi H, Abdi M. Association of HaeIII single nucleotide polymorphisms in the SLC2A1 gene with risk of diabetic nephropathy; evidence from Kurdish patients with type 2 diabetes mellitus. QJM. 2016;109(6):399-404. doi:10.1093/qjmed/hcv149

54. Yang JH, Downes K, Howson JM, Nutland S, Stevens HE, Walker NM, Todd JA. Evidence of association with type 1 diabetes in the SLC11A1 gene region. BMC Med Genet. 2011;12:59. doi:10.1186/1471-2350-12-59

55.Du Toit E, Browne L, Irving-Rodgers H, Massa HM, Fozzard N, Jennings MP, Peak IR. Effect of GPR84 deletion on obesity and diabetes development in mice fed long chain or medium chain fatty acid rich diets. Eur J Nutr. 2018;57(5):1737-1746. doi:10.1007/s00394-017-1456-5

56. Hirose H, Yamasaki T, Ogino M, Mizojiri R, Tamura-Okano Y, Yashiro H, Muraki Y, Nakano Y, Sugama J, Hata A, et al. Discovery of novel 5-oxa2,6-diazaspiro[3.4]oct-6-ene derivatives as potent, selective, and orally available somatostatin receptor subtype 5 (SSTR5) antagonists for treatment of type 2 diabetes mellitus. Bioorg Med Chem. 2017;25(15):4175-4193. doi:10.1016/j.bmc.2017.06.007

57.Zhang YX, Liu Y, Dong J, Wang YX, Wang J, Zhuang GQ, Han SJ, Guo QQ, Luo YX, Zhang J, et al. An exploratory study of the association between KCNB1 rs1051295 and type 2 diabetes and its related traits in Chinese Han population. PLoS One. 2013;8(2):e56365. doi:10.1371/journal.pone.0056365

58. Griffin JWD, Liu Y, Bradshaw PC, Wang K. In Silico Preliminary Association of Ammonia Metabolism Genes GLS, CPS1, and GLUL with 
Risk of Alzheimer's Disease, Major Depressive Disorder, and Type 2 Diabetes. J Mol Neurosci. 2018;64(3):385-396. doi:10.1007/s12031-0181035-0

59.Zouidi F, Stayoussef M, Bouzid D, Fourati H, Abida O, João C, Ayed MB, Fakhfakh R, Thouraya K, Monjia H, et al. Association of BANK1 and cytokine gene polymorphisms with type 1 diabetes in Tunisia. Gene. 2014;536(2):296-301. doi:10.1016/j.gene.2013.12.008

60.Trombetta M, Bonetti S, Boselli M, Turrini F, Malerba G, Trabetti E, Pignatti $\mathrm{P}$, Bonora E, Bonadonna RC. CACNA1E variants affect beta cell function in patients with newly diagnosed type 2 diabetes. the Verona newly diagnosed type 2 diabetes study (VNDS) 3. PLoS One. 2012;7(3):e32755. doi:10.1371/journal.pone.0032755

61.Alharbi KK, Ali Khan I, Syed R, Alharbi FK, Mohammed AK, Vinodson B, Al-Daghri NM. Association of JAZF1 and TSPAN8/LGR5 variants in relation to type 2 diabetes mellitus in a Saudi population. Diabetol Metab Syndr. 2015;7:92. doi:10.1186/s13098-015-0091-7

62.Ikarashi N, Mizukami N, Kon R, Kaneko M, Uchino R, Fujisawa I, Fukuda N, Sakai H, Kamei J. Study of the Mechanism Underlying the Onset of Diabetic Xeroderma Focusing on an Aquaporin-3 in a StreptozotocinInduced Diabetic Mouse Model. Int J Mol Sci. 2019;20(15):3782. doi:10.3390/ijms20153782

63.Dharmadhikari G, Stolz K, Hauke M, Morgan NG, Varki A, de Koning E, Kelm S, Maedler K. Siglec-7 restores $\beta$-cell function and survival and reduces inflammation in pancreatic islets from patients with diabetes. Sci Rep. 2017;7:45319. doi:10.1038/srep45319

64.Sutton BS, Palmer ND, Langefeld CD, Xue B, Proctor A, Ziegler JT, Haffner SM, Norris JM, Bowden DW.Association of SSTR2 polymorphisms and glucose homeostasis phenotypes: the Insulin Resistance Atherosclerosis Family Study. Diabetes. 2009;58(6):1457-1462. doi:10.2337/db08-0189

65.Deng Z, Shen J, Ye J, Shu Q, Zhao J, Fang M, Zhang T. Association between single nucleotide polymorphisms of delta/notch-like epidermal growth factor (EGF)-related receptor (DNER) and Delta-like 1 Ligand (DLL 1) with the risk of type 2 diabetes mellitus in a Chinese Han population. Cell Biochem Biophys. 2015;71(1):331-335. doi:10.1007/s12013-014-0202-3 
66.Tillmanns J, Hoffmann D, Habbaba Y, Schmitto JD, Sedding D, Fraccarollo D, Galuppo P, Bauersachs J. Fibroblast activation protein alpha expression identifies activated fibroblasts after myocardial infarction. J Mol Cell Cardiol. 2015;87:194-203. doi:10.1016/j.yjmcc.2015.08.016

67.Cui J, Randell E, Renouf J, Sun G, Green R, Han FY, Xie YG. Thrombospondin-4 1186G>C (A387P) is a sex-dependent risk factor for myocardial infarction: a large replication study with increased sample size from the same population. Am Heart J. 2006;152(3):543.e1-543.e5435. doi:10.1016/j.ahj.2006.06.002

68.Li W, Zhang F, Ju C, Lv S, Huang K. The role of CD27-CD70 signaling in myocardial infarction and cardiac remodeling. Int J Cardiol. 2019;278:210216. doi:10.1016/j.ijcard.2018.11.132

69. Cho HM, Lee KH, Shen YM, Shin TJ, Ryu PD, Choi MC, Kang KS, Cho JY. Transplantation of hMSCs Genome Edited with LEF1 Improves CardioProtective Effects in Myocardial Infarction. Mol Ther Nucleic Acids. 2020;19:1186-1197. doi:10.1016/j.omtn.2020.01.007

70.Ruiz-Villalba A, Romero JP, Hernández SC, Vilas-Zornoza A, Fortelny N, Castro-Labrador L, San Martin-Uriz P, Lorenzo-Vivas E, García-Olloqui P, Palacio M, et al. Single-Cell RNA Sequencing Analysis Reveals a Crucial Role for CTHRC1 (Collagen Triple Helix Repeat Containing 1) Cardiac Fibroblasts After Myocardial Infarction. Circulation. 2020;142(19):18311847. doi:10.1161/CIRCULATIONAHA.119.044557

71.Puzianowska-Kuźnicka M. ESR1 in myocardial infarction. Clin Chim Acta. 2012;413(1-2):81-87. doi:10.1016/j.cca.2011.10.028

72.Lin CF, Su CJ, Liu JH, Chen ST, Huang HL, Pan SL. Potential Effects of CXCL9 and CCL20 on Cardiac Fibrosis in Patients with Myocardial Infarction and Isoproterenol-Treated Rats. J Clin Med. 2019;8(5):659. doi: $10.3390 / \mathrm{jcm} 8050659$

73.Zhao L, Chen M, Yang X. Serpina3 in myocardial infarction. Int J Cardiol. 2020;306:8. doi:10.1016/j.ijcard.2020.02.045

74.Jung C, Gené GG, Tomás M, Plata C, Selent J, Pastor M, Fandos C, Senti M, Lucas G, Elosua R, et al. A gain-of-function SNP in TRPC4 cation channel protects against myocardial infarction. Cardiovasc Res. 2011;91(3):465-471. doi:10.1093/cvr/cvr083 
75.Ansani L, Marchesini J, Pestelli G, Luisi GA, Scillitani G, Longo G, Milani D, Serino ML, Tisato V, Gemmati D. F13A1 Gene Variant (V34L) and Residual Circulating FXIIIA Levels Predict Short- and Long-Term Mortality in Acute Myocardial Infarction after Coronary Angioplasty. Int J Mol Sci. 2018;19(9):2766. doi:10.3390/ijms19092766

76. Tan B, Liu M, Yang Y, Liu L, Meng F. Low expression of PIK3C2A gene: A potential biomarker to predict the risk of acute myocardial infarction. Medicine (Baltimore). 2019;98(14):e15061. doi:10.1097/MD.0000000000015061

77.Zhang X, Liao C, Sun K, Liu L, Xu D. A Soluble Epoxide Hydrolase Inhibitor Upregulated KCNJ12 and KCNIP2 by Downregulating MicroRNA-29 in a Mouse Model of Myocardial Infarction. Heart Surg Forum. 2020;23(5):E579-E585. doi:10.1532/hsf.2999

78. Fukuda H, Ito S, Watari K, Mogi C, Arisawa M, Okajima F, Kurose H, Shuto S. Identification of a Potent and Selective GPR4 Antagonist as a Drug Lead for the Treatment of Myocardial Infarction. ACS Med Chem Lett. 2016;7(5):493-497. doi:10.1021/acsmedchemlett.6b00014

79. Wang HB, Yang J, Shuai W, Yang J, Liu LB, Xu M, Tang QZ. Deletion of Microfibrillar-Associated Protein 4 Attenuates Left Ventricular Remodeling and Dysfunction in Heart Failure. J Am Heart Assoc. 2020;9(17):e015307. doi:10.1161/JAHA.119.015307

80.Kayama Y, Minamino T, Toko H, Sakamoto M, Shimizu I, Takahashi H, Okada S, Tateno K, Moriya J, Yokoyama M, et al. Cardiac 12/15 lipoxygenase-induced inflammation is involved in heart failure. J Exp Med. 2009;206(7):1565-1574. doi:10.1084/jem.20082596

81.Hua X, Wang YY, Jia P, Xiong Q, Hu Y, Chang Y, Lai S, Xu Y, Zhao Z, Song J. Multi-level transcriptome sequencing identifies COL1A1 as a candidate marker in human heart failure progression. BMC Med. 2020;18(1):2. doi:10.1186/s12916-019-1469-4

82.Gombos T, Förhécz Z, Pozsonyi Z, Jánoskuti L, Prohászka Z, Karádi I. Long-Term Survival and Apolipoprotein A1 Level in Chronic Heart Failure: Interaction With Tumor Necrosis Factor $\alpha-308$ G/A Polymorphism. J Card Fail. 2017;23(2):113-120. doi:10.1016/j.cardfail.2016.06.004

83. Westermann D, Becher PM, Lindner D, Savvatis K, Xia Y, Fröhlich M, Hoffmann S, Schultheiss HP, Tschöpe C. Selective PDE5A inhibition with 
sildenafil rescues left ventricular dysfunction, inflammatory immune response and cardiac remodeling in angiotensin II-induced heart failure in vivo. Basic Res Cardiol. 2012;107(6):308. doi:10.1007/s00395-012-0308-y

84. Koller L, Blum S, Korpak M, Richter B, Goliasch G, Zorn G, Brekalo M, Maurer G, Wojta J, Pacher R, et al. Predictive power of the fractalkine receptor CX3CR1 on CD4 T cells in patients with chronic heart failure. Int $\mathrm{J}$ Cardiol. 2014;171(1):96-97. doi:10.1016/j.ijcard.2013.11.082

85.Li Y, Song D, Mao L, Abraham DM, Bursac N. Lack of Thy1 defines a pathogenic fraction of cardiac fibroblasts in heart failure. Biomaterials. 2020;236:119824. doi:10.1016/j.biomaterials.2020.119824

86. Mueller KA, Tavlaki E, Schneider M, Jorbenadze R, Geisler T, Kandolf R, Gawaz M, Mueller II, Zuern CS. Gremlin-1 identifies fibrosis and predicts adverse outcome in patients with heart failure undergoing endomyocardial biopsy. J Card Fail. 2013;19(10):678-684. doi:10.1016/j.cardfail.2013.09.001

87.Andenæs K, Lunde IG, Mohammadzadeh N, Dahl CP, Aronsen JM, Strand ME, Palmero S, Sjaastad I, Christensen G, Engebretsen KVT, et al. The extracellular matrix proteoglycan fibromodulin is upregulated in clinical and experimental heart failure and affects cardiac remodeling. PLoS One. 2018;13(7):e0201422. $\quad$ Published $2018 \quad$ Jul 27. doi:10.1371/journal.pone.0201422

88. Abuzaanona A, Lanfear D. Pharmacogenomics of the Natriuretic Peptide System in Heart Failure. Curr Heart Fail Rep. 2017;14(6):536-542. doi:10.1007/s11897-017-0365-5

89.Bai Y, Zhang P, Zhang X, Huang J, Hu S, Wei Y. LTBP-2 acts as a novel marker in human heart failure - a preliminary study. Biomarkers. 2012;17(5):407-415. doi:10.3109/1354750X.2012.677860

90.Engebretsen KV, Lunde IG, Strand ME, Waehre A, Sjaastad I, Marstein HS, Skrbic B, Dahl CP, Askevold ET, Christensen G, et al. Lumican is increased in experimental and clinical heart failure, and its production by cardiac fibroblasts is induced by mechanical and proinflammatory stimuli. FEBS J. 2013;280(10):2382-2398. doi:10.1111/febs.12235

91.Tao R, Fan Q, Zhang H, Xie H, Lu L, Gu G, Wang F, Xi R, Hu J, Chen Q, et al. Prognostic Significance of Interleukin-34 (IL-34) in Patients With 
Chronic Heart Failure With or Without Renal Insufficiency. J Am Heart Assoc. 2017;6(4):e004911. doi:10.1161/JAHA.116.004911

92.De Keulenaer GW, Feyen E, Dugaucquier L, Shakeri H, Shchendrygina A, Belenkov YN, Brink M, Vermeulen Z, Segers VFM. Mechanisms of the Multitasking Endothelial Protein NRG-1 as a Compensatory Factor During Chronic Heart Failure. Circ Heart Fail. 2019;12(10):e006288. doi:10.1161/CIRCHEARTFAILURE.119.006288

93.Zeng L, Gu N, Chen J, Jin G, Zheng Y. IRX1 hypermethylation promotes heart failure by inhibiting CXCL14 expression. Cell Cycle. 2019;18(23):3251-3262. doi:10.1080/15384101.2019.1673099

94.Altara R, Manca M, Hessel MH, Gu Y, van Vark LC, Akkerhuis KM, Staessen JA, Struijker-Boudier HA, Booz GW, Blankesteijn WM. CXCL10 Is a Circulating Inflammatory Marker in Patients with Advanced Heart Failure: a Pilot Study. J Cardiovasc Transl Res. 2016;9(4):302-314. doi:10.1007/s12265-016-9703-3

95.Petrie MC, Padmanabhan N, McDonald JE, Hillier C, Connell JM, McMurray JJ. Angiotensin converting enzyme (ACE) and non-ACE dependent angiotensin II generation in resistance arteries from patients with heart failure and coronary heart disease. J Am Coll Cardiol. 2001;37(4):1056-1061. doi:10.1016/s0735-1097(01)01111-1

96. Meissner A, Yang J, Kroetsch JT, Sauvé M, Dax H, Momen A, NoyanAshraf $\mathrm{MH}$, Heximer S, Husain M, et al. Tumor necrosis factor- $\alpha$-mediated downregulation of the cystic fibrosis transmembrane conductance regulator drives pathological sphingosine-1-phosphate signaling in a mouse model of heart failure. Circulation. 2012;125(22):2739-2750. doi:10.1161/CIRCULATIONAHA.111.047316

97. Wei X, Wu B, Zhao J, Zeng Z, Xuan W, Cao S, Huang X, Asakura M, Xu D, Bin J, et al. Myocardial Hypertrophic Preconditioning Attenuates Cardiomyocyte Hypertrophy and Slows Progression to Heart Failure Through Upregulation of S100A8/A9. Circulation. 2015;131(17):15061517. doi:10.1161/CIRCULATIONAHA.114.013789

98. Holme I, Aastveit AH, Hammar N, Jungner I, Walldius G. Haptoglobin and risk of myocardial infarction, stroke, and congestive heart failure in 342,125 men and women in the Apolipoprotein MOrtality RISk study (AMORIS). Ann Med. 2009;41(7):522-532. doi:10.1080/07853890903089453 
99.de Denus S, Dubé MP, Fouodjio R, Huynh T, LeBlanc MH, Lepage S, Sheppard R, Giannetti N, Lavoie J, Mansour A, et al. A prospective study of the impact of AGTR1 A1166C on the effects of candesartan in patients with heart failure. Pharmacogenomics. 2018;19(7):599-612. doi:10.2217/pgs2018-0004

100. Angrisano T, Schiattarella GG, Keller S, Pironti G, Florio E, Magliulo F, Bottino R, Pero R, Lembo F, Avvedimento EV, et al. Epigenetic switch at atp2a2 and myh7 gene promoters in pressure overload-induced heart failure. PLoS One. 2014;9(9):e106024. doi:10.1371/journal.pone.0106024

101. Amir O, Rogowski O, David M, Lahat N, Wolff R, Lewis BS. Circulating interleukin-10: association with higher mortality in systolic heart failure patients with elevated tumor necrosis factor-alpha. Isr Med Assoc J. 2010;12(3):158-162.

102. Taylor MR, Slavov D, Humphrey K, Zhao L, Cockroft J, Zhu X, Lavori P, Bristow MR, Mestroni L, Lazzeroni LC. Pharmacogenetic effect of an endothelin-1 haplotype on response to bucindolol therapy in chronic heart failure. Pharmacogenet Genomics. 2009;19(1):35-43. doi:10.1097/FPC.0b013e328317cc57

103. Liang S, Xinyong C, Hongmin Z, Jing W, Lang H, Ping Z. TLR2 and TLR3 expression as a biomarker for the risk of doxorubicin-induced heart failure. Toxicol Lett. 2018;295:205-211. doi:10.1016/j.toxlet.2018.06.1219

104. Raman K, O'Donnell MJ, Czlonkowska A, Duarte YC, LopezJaramillo P, Peñaherrera E, Sharma M, Shoamanesh A, Skowronska M, Yusuf S et al. Peripheral Blood MCEMP1 Gene Expression as a Biomarker for Stroke Prognosis. Stroke. 2016;47(3):652-658. doi:10.1161/STROKEAHA.115.011854

105. Wells BJ, Hueston WJ. Are thyroid peroxidase antibodies associated with cardiovascular disease risk in patients with subclinical hypothyroidism?. Clin Endocrinol (Oxf). 2005;62(5):580-584. doi:10.1111/j.1365-2265.2005.02262.x

106. Ptaszynska-Kopczynska K, Marcinkiewicz-Siemion M, Lisowska A, Waszkiewicz E, Witkowski M, Jasiewicz M, Miklasz P, Jakim P, Galar B, Musial WJ, et al. Alterations of soluble TWEAK and CD163 concentrations in patients with chronic heart failure. Cytokine. 2016;80:7-12. doi:10.1016/j.cyto.2016.02.005 
107. Grisoni ML, Proust C, Alanne M, Desuremain M, Salomaa V, Kuulasmaa K, Cambien F, Nicaud V, Wiklund PG, Virtamo J, et al. Lack of association between polymorphisms of the IL18R1 and IL18RAP genes and cardiovascular risk: the MORGAM Project. BMC Med Genet. 2009;10:44. doi:10.1186/1471-2350-10-44

108. Bardien-Kruger S, Wulff H, Arieff Z, Brink P, Chandy KG, Corfield V. Characterisation of the human voltage-gated potassium channel gene, KCNA7, a candidate gene for inherited cardiac disorders, and its exclusion as cause of progressive familial heart block I (PFHBI). Eur J Hum Genet. 2002;10(1):36-43. doi:10.1038/sj.ejhg.5200739

109. Totsune K, Takahashi K, Mackenzie HS, Murakami O, Arihara Z, Sone $\mathrm{M}$, Mouri $\mathrm{T}$, Brenner BM, Ito $\mathrm{S}$. Increased gene expression of adrenomedullin and adrenomedullin-receptor complexes, receptor-activity modifying protein (RAMP)2 and calcitonin-receptor-like receptor (CRLR) in the hearts of rats with congestive heart failure. Clin Sci (Lond). 2000;99(6):541-546.

110. Li X, Wang G, QiLi M, Liang H, Li T, E X, Feng Y, Zhang Y, Liu X, Qian M, et al. Aspirin Reduces Cardiac Interstitial Fibrosis by Inhibiting Erk1/2-Serpine2 and P-Akt Signalling Pathways. Cell Physiol Biochem. 2018;45(5):1955-1965. doi:10.1159/000487972

111. Deckx S, Heggermont W, Carai P, Rienks M, Dresselaers T, Himmelreich U, van Leeuwen R, Lommen W, van der Velden J, Gonzalez A, et al. Osteoglycin prevents the development of age-related diastolic dysfunction during pressure overload by reducing cardiac fibrosis and inflammation. Matrix Biol. 2018;66:110-124. doi:10.1016/j.matbio.2017.09.002

112. Ichihara S, Senbonmatsu T, Price E Jr, Ichiki T, Gaffney FA, Inagami T. Angiotensin II type 2 receptor is essential for left ventricular hypertrophy and cardiac fibrosis in chronic angiotensin II-induced hypertension. Circulation. 2001;104(3):346-351. doi:10.1161/01.cir.104.3.346

113. Paik DT, Rai M, Ryzhov S, Sanders LN, Aisagbonhi O, Funke MJ, Feoktistov I, Hatzopoulos AK. Wnt10b Gain-of-Function Improves Cardiac Repair by Arteriole Formation and Attenuation of Fibrosis. Circ Res. 2015;117(9):804-816. doi:10.1161/CIRCRESAHA.115.306886 
114. Cai W, Tao J, Zhang X, Tian X, Liu T, Feng X, Bai J, Yan C, Han Y.Contribution of homeostatic chemokines CCL19 and CCL21 and their receptor CCR7 to coronary artery disease. Arterioscler Thromb Vasc Biol. 2014;34(9):1933-1941. doi:10.1161/ATVBAHA.113.303081

115. Mo XG, Liu W, Yang Y, Imani S, Lu S, Dan G, Nie X, Yan J, Zhan $\mathrm{R}$, Li X, et al. NCF2, MYO1F, S1PR4, and FCN1 as potential noninvasive diagnostic biomarkers in patients with obstructive coronary artery: A weighted gene co-expression network analysis. J Cell Biochem. 2019;120(10):18219-18235. doi:10.1002/jcb.29128

116. Sun H, Fang F, Li K, Zhang H, Zhang M, Zhang L, Li J, Qin Y, Wei Y. Circulating ESM-1 levels are correlated with the presence of coronary artery disease in patients with obstructive sleep apnea. Respir Res. 2019;20(1):188. doi:10.1186/s12931-019-1143-6

117. Martinelli N, Girelli D, Lunghi B, Pinotti M, Marchetti G, Malerba G, Pignatti PF, Corrocher R, Olivieri O, Bernardi F. Polymorphisms at LDLR locus may be associated with coronary artery disease through modulation of coagulation factor VIII activity and independently from lipid profile. Blood. 2010;116(25):5688-5697. doi:10.1182/blood-2010-03-277079

118. Zhao X, Li Y, Yan Y, Ma X, Guo C. Methylation of CpG sites in C1QTNF1 (C1q and tumor necrosis factor related protein 1) differs by gender in acute coronary syndrome in Han population: a case-control study. Genes Genomics. 2020;42(6):681-689. doi:10.1007/s13258-020-00936-6

119. Assimes TL, Knowles JW, Priest JR, Basu A, Volcik KA, Southwick A, Tabor HK, Hartiala J, Allayee H, Grove ML, et al. Common polymorphisms of ALOX5 and ALOX5AP and risk of coronary artery disease. Hum Genet. 2008;123(4):399-408. doi:10.1007/s00439-008-0489-5

120. Piechota M, Banaszewska A, Dudziak J, Slomczynski M, Plewa R. Highly upregulated expression of CD36 and MSR1 in circulating monocytes of patients with acute coronary syndromes. Protein J. 2012;31(6):511-518. doi:10.1007/s10930-012-9431-8

121. Desch KC, Ozel AB, Halvorsen M, Jacobi PM, Golden K, Underwood M, Germain M, Tregouet DA, Reitsma PH, Kearon C, et al. Whole-exome sequencing identifies rare variants in STAB2 associated with venous thromboembolic disease. Blood. 2020;136(5):533-541. doi:10.1182/blood.2019004161 
122. Fu Y, Gao C, Liang Y, Wang M, Huang Y, Ma W, Li T, Jia Y, Yu F, Zhu W, et al. Shift of Macrophage Phenotype Due to Cartilage Oligomeric Matrix Protein Deficiency Drives Atherosclerotic Calcification. Circ Res. 2016;119(2):261-276. doi:10.1161/CIRCRESAHA.115.308021

123. Wu S, Hsu LA, Cheng ST, Teng MS, Yeh CH, Sun YC, Huang HL, Ko YL. Circulating YKL-40 level, but not CHI3L1 gene variants, is associated with atherosclerosis-related quantitative traits and the risk of peripheral artery disease. Int J Mol Sci. 2014;15(12):22421-22437. doi:10.3390/ijms151222421

124. Monroy-Muñoz IE, Angeles-Martinez J, Posadas-Sánchez R, Villarreal-Molina T, Alvarez-León E, Flores-Dominguez C, CardosoSaldaña G, Medina-Urrutia A, Juárez-Rojas JG, Posadas-Romero C, et al. PLA2G2A polymorphisms are associated with metabolic syndrome and type 2 diabetes mellitus. Results from the genetics of atherosclerotic disease Mexican study. Immunobiology. 2017;222(10):967-972. doi:10.1016/j.imbio.2016.08.014

125. Pi S, Mao L, Chen J, Shi H, Liu Y, Guo X, Li Y, Zhou L, He H, Yu $\mathrm{C}$, et al. The P2RY12 receptor promotes VSMC-derived foam cell formation by inhibiting autophagy in advanced atherosclerosis. Autophagy. 2020;1-21. doi:10.1080/15548627.2020.1741202

126. de Vries MA, Trompet S, Mooijaart SP, Smit RA, Böhringer S, Castro Cabezas M, Jukema JW. Complement receptor 1 gene polymorphisms are associated with cardiovascular risk. Atherosclerosis. 2017;257:16-21. doi:10.1016/j.atherosclerosis.2016.12.017

127. Osterholm C, Folkersen L, Lengquist M, Pontén F, Renné T, Li J, Hedin U. Increased expression of heparanase in symptomatic carotid atherosclerosis. Atherosclerosis. 2013;226(1):67-73. doi:10.1016/j.atherosclerosis.2012.09.030

128. Norata GD, Garlanda C, Catapano AL. The long pentraxin PTX3: a modulator of the immunoinflammatory response in atherosclerosis and cardiovascular diseases. Trends Cardiovasc Med. 2010;20(2):35-40. doi:10.1016/j.tcm.2010.03.005

129. Koch W, Schrempf M, Erl A, Mueller JC, Hoppmann P, Schömig A, Kastrati A. 4G/5G polymorphism and haplotypes of SERPINE1 in 
atherosclerotic diseases of coronary arteries. Thromb Haemost. 2010;103(6):1170-1180. doi:10.1160/TH09-10-0702

130. Sasagawa S, Nishimura Y, Sawada H, Zhang E, Okabe S, Murakami S, Ashikawa Y, Yuge M, Kawaguchi K, Kawase R, et al. Comparative Transcriptome Analysis Identifies CCDC80 as a Novel Gene Associated with Pulmonary Arterial Hypertension. Front Pharmacol. 2016;7:142. doi:10.3389/fphar.2016.00142

131. Wu Y, Li Q, Yang K, Xiao C. Association of CMA1 gene tag single nucleotide polymorphisms with essential hypertension in Yi population from Yunnan. Chinese. 2014;31(4):449-454. doi: 10.3760/cma.j.issn.10039406.2014.04.008

132. Sato W, Sato Y. Midkine in nephrogenesis, hypertension and kidney diseases. Br J Pharmacol. 2014;171(4):879-887. doi:10.1111/bph.12418

133. Kohara K, Tabara Y, Nakura J, Imai Y, Ohkubo T, Hata A, Soma M, Nakayama $\mathrm{T}$, Umemura $\mathrm{S}$, Hirawa $\mathrm{N}$, et al. Identification of hypertensionsusceptibility genes and pathways by a systemic multiple candidate gene approach: the millennium genome project for hypertension. Hypertens Res. 2008;31(2):203-212. doi:10.1291/hypres.31.203

134. Wen G, Wessel J, Zhou W, Ehret GB, Rao F, Stridsberg M, Mahata SK, Gent PM, Das M, Cooper RS, et al. An ancestral variant of Secretogranin II confers regulation by PHOX2 transcription factors and association with hypertension. Hum Mol Genet. 2007;16(14):1752-1764. doi: $10.1093 / \mathrm{hmg} / \mathrm{ddm} 123$

135. Seidelmann SB, Vardeny O, Claggett B, Yu B, Shah AM, Ballantyne CM, Selvin E, MacRae CA, Boerwinkle E, Solomon SD. An NPPB Promoter Polymorphism Associated With Elevated N-Terminal pro-B-Type Natriuretic Peptide and Lower Blood Pressure, Hypertension, and Mortality. J Am Heart Assoc. 2017;6(4):e005257. doi:10.1161/JAHA.116.005257

136. Shi L, Tian C, Sun L, Cao F, Meng Z. The lncRNA TUG1/miR-1455 p/FGF10 regulates proliferation and migration in VSMCs of hypertension. Biochem Biophys Res Commun. 2018;501(3):688-695. doi:10.1016/j.bbrc.2018.05.049

137. Woon PY, Kaisaki PJ, Bragança J, Bihoreau MT, Levy JC, Farrall M, Gauguier D. Aryl hydrocarbon receptor nuclear translocator-like (BMAL1) is associated with susceptibility to hypertension and type 2 diabetes. Proc 
Natl Acad Sci U S A. 2007;104(36):14412-14417. doi:10.1073/pnas.0703247104

138. Leng Q, Kahle KT, Rinehart J, MacGregor GG, Wilson FH, Canessa CM, Lifton RP, Hebert SC. WNK3, a kinase related to genes mutated in hereditary hypertension with hyperkalaemia, regulates the $\mathrm{K}+$ channel ROMK1 (Kir1.1). J Physiol. 2006;571(Pt 2):275-286. doi:10.1113/jphysiol.2005.102202

139. Zicha J, Dobešová Z, Zídek V, Silhavý J, Simáková M, Mlejnek P, Vaněčková I, Kuneš J, Pravenec M. Pharmacogenetic analysis of captopril effects on blood pressure: possible role of the Ednrb (endothelin receptor type B) candidate gene. Physiol Res. 2014;63(2):263-265. doi:10.33549/physiolres.932732

140. Maloney JP, Stearman RS, Bull TM, Calabrese DW, Tripp-Addison ML, Wick MJ, Broeckel U, Robbins IM, Wheeler LA, Cogan JD, et al. Loss-of-function thrombospondin-1 mutations in familial pulmonary hypertension. Am J Physiol Lung Cell Mol Physiol. 2012;302(6):L541L554. doi:10.1152/ajplung.00282.2011

141. Ouyang Y, Wu H, Tan A, Yang H, Gao Y, Li H, Lu S, Hu Y, Tang X, Zhang H. E-selectin gene polymorphism (A561C) and essential hypertension. Meta-analysis in the Chinese population. Herz. 2015;40 Suppl 2:197-202. doi:10.1007/s00059-014-4122-1

142. Wang L, Li H, Yang B, Guo L, Han X, Li L, Li M, Huang J, Gu D. The Hypertension Risk Variant Rs820430 Functions as an Enhancer of SLC4A7. Am J Hypertens. 2017;30(2):202-208. doi:10.1093/ajh/hpw127

143. Kerty E, Heuser K, Indahl UG, Berg PR, Nakken S, Lien S, Omholt SW, Ottersen OP, Nagelhus EA.Is the brain water channel aquaporin-4 a pathogenetic factor in idiopathic intracranial hypertension? Results from a combined clinical and genetic study in a Norwegian cohort. Acta Ophthalmol. 2013;91(1):88-91. doi:10.1111/j.1755-3768.2011.02231.x

144. Lambert M, Capuano V, Boet A, Tesson L, Bertero T, Nakhleh MK, Remy S, Anegon I, Pechoux C, Hautefort A, et al. Characterization of Kcnk3-Mutated Rat, a Novel Model of Pulmonary Hypertension. Circ Res. 2019;125(7):678-695. doi:10.1161/CIRCRESAHA.119.314793

145. Buchner DA, Geisinger JM, Glazebrook PA, Morgan MG, Spiezio SH, Kaiyala KJ, Schwartz MW, Sakurai T, Furley AJ, Kunze DL, et al. The 
juxtaparanodal proteins CNTNAP2 and TAG1 regulate diet-induced obesity.

Mamm Genome. 2012;23(7-8):431-442. doi:10.1007/s00335-012-9400-8

146. Shi Y, Long F. Hedgehog signaling via Gli2 prevents obesity induced by high-fat diet in adult mice. Elife. 2017;6:e31649. doi:10.7554/eLife.31649

147. Unamuno X, Gómez-Ambrosi J, Ramírez B, Rodríguez A, Becerril S, Valentí V, Moncada R, Silva C, Salvador J, et al. Dermatopontin, A Novel Adipokine Promoting Adipose Tissue Extracellular Matrix Remodelling and Inflammation in Obesity. J Clin Med. 2020;9(4):1069. doi:10.3390/jcm9041069

148. Zhang L, Reidy SP, Nicholson TE, Lee HJ, Majdalawieh A, Webber C, Stewart BR, Dolphin P, Ro HS. The role of AEBP1 in sex-specific dietinduced obesity. Mol Med. 2005;11(1-12):39-47. doi:10.2119/200500021.Ro

149. Anveden $\AA$ A, Sjöholm K, Jacobson P, Palsdottir V, Walley AJ, Froguel P, Al-Daghri N, McTernan PG, Mejhert N, Arner P, et al. ITIH-5 expression in human adipose tissue is increased in obesity. Obesity (Silver Spring). 2012;20(4):708-714. doi:10.1038/oby.2011.268

150. Kochumon S, Madhoun AA, Al-Rashed F, Azim R, Al-Ozairi E, AlMulla F, Ahmad R. Adipose tissue gene expression of CXCL10 and CXCL11 modulates inflammatory markers in obesity: implications for metabolic inflammation and insulin resistance. Ther Adv Endocrinol Metab. 2020;11:2042018820930902. doi:10.1177/2042018820930902

151. Mwangi SM, Nezami BG, Obukwelu B, Anitha M, Marri S, Fu P, Epperson MF, Le NA, Shanmugam M, Sitaraman SV, et al. Glial cell linederived neurotrophic factor protects against high-fat diet-induced obesity. Am J Physiol Gastrointest Liver Physiol. 2014;306(6):G515-G525. doi:10.1152/ajpgi.00364.2013

152. Högberg T, Frimurer TM, Sasmal PK. Melanin concentrating hormone receptor 1 (MCHR1) antagonists-Still a viable approach for obesity treatment?. Bioorg Med Chem Lett. 2012;22(19):6039-6047. doi:10.1016/j.bmcl.2012.08.025

153. Mazzarella L, Botteri E, Matthews A, Gatti E, Di Salvatore D, Bagnardi V, Breccia M, Montesinos P, Bernal T, Gil C, et al. Obesity is a risk factor for acute promyelocytic leukemia: evidence from population and 
cross-sectional studies and correlation with FLT3 mutations and polyunsaturated fatty acid metabolism. Haematologica. 2020;105(6):15591566. doi:10.3324/haematol.2019.223925

154. Mirea AM, Stienstra R, Kanneganti TD, Tack CJ, Chavakis T, Toonen EJM, Joosten LAB. Mice Deficient in the IL-1 $\beta$ Activation Genes Prtn3, Elane, and Casp1 Are Protected Against the Development of ObesityInduced NAFLD. Inflammation. 2020;43(3):1054-1064. doi:10.1007/s10753-020-01190-4

155. Piquer-Garcia I, Campderros L, Taxerås SD, Gavaldà-Navarro A, Pardo R, Vila M, Pellitero S, Martínez E, Tarascó J, Moreno P, et al. A Role for Oncostatin $\mathrm{M}$ in the Impairment of Glucose Homeostasis in Obesity. J Clin Endocrinol Metab. 2020;105(3):e337-e348. doi:10.1210/clinem/dgz090

156. Quinn LS, Anderson BG. Interleukin-15, IL-15 Receptor-Alpha, and Obesity: Concordance of Laboratory Animal and Human Genetic Studies. J Obes. 2011;2011:456347. doi:10.1155/2011/456347

157. Wang J, Sukhova GK, Liu J, Ozaki K, Lesner A, Libby P, Kovanen PT, Shi GP. Cathepsin G deficiency reduces periaortic calcium chloride injury-induced abdominal aortic aneurysms in mice. J Vasc Surg. 2015;62(6):1615-1624. doi:10.1016/j.jvs.2014.06.004

158. Safa A, Rashidinejad HR, Khalili M, Dabiri S, Nemati M, Mohammadi MM, Jafarzadeh A. Higher circulating levels of chemokines CXCL10, CCL20 and CCL22 in patients with ischemic heart disease. Cytokine. 2016;83:147-157. doi:10.1016/j.cyto.2016.04.006

159. Chen C, Peng H, Zeng Y, Dong G. CD14, CD163, and CCR1 are involved in heart and blood communication in ischemic cardiac diseases. $\mathrm{J}$ Int Med Res. 2020;48(9):300060520951649. doi:10.1177/0300060520951649

160. Zhou QL, Teng F, Zhang YS, Sun Q, Cao YX, Meng GW. FPR1 gene silencing suppresses cardiomyocyte apoptosis and ventricular remodeling in rats with ischemia/reperfusion injury through the inhibition of MAPK signaling pathway. Exp Cell Res. 2018;370(2):506-518. doi:10.1016/j.yexcr.2018.07.016

161. Hu Z, Liu J, Song Z, Hou Q, Fan X, Hou D. Variants in the Atherogenic ALOX5AP, THBD, and KNG1 Genes Potentiate the Risk of Ischemic Stroke via a Genetic Main Effect and Epistatic Interactions in a 
Chinese Population. J Stroke Cerebrovasc Dis. 2015;24(9):2060-2068. doi:10.1016/j.jstrokecerebrovasdis.2015.04.036

162. Lou Y, Wang S, Qu J, Zheng J, Jiang W, Lin Z, Zhang S. miR-424 promotes cardiac ischemia/reperfusion injury by direct targeting of CRISPLD2 and regulating cardiomyocyte pyroptosis. Int J Clin Exp Pathol. 2018;11(7):3222-3235.

163. Zhang X, Li L, Zhang Q, Wei Q, Lin J, Jia J, Zhang J, Yan T, Lv Y, Jiang X, et al. CD38 Causes Autophagic Flux Inhibition and Cardiac Dysfunction Through a Transcriptional Inhibition Pathway Under Hypoxia/Ischemia Conditions. Front Cell Dev Biol. 2020;8:191. doi:10.3389/fcell.2020.00191

164. Chen W, Li S, Liu Q, Yang Y, Wei L, Lu Y. MicroRNA-342-5p protects against myocardial ischemia-reperfusion injury by targeting the GPRC5A pathway. 2020;75(6):271-274. doi:10.1691/ph.2020.0383

165. Li PL, Liu H, Chen GP, Li L, Shi HJ, Nie HY, Liu Z, Hu YF, Yang J, Zhang P, et al. STEAP3 (Six-Transmembrane Epithelial Antigen of Prostate 3) Inhibits Pathological Cardiac Hypertrophy. Hypertension. 2020;76(4):1219-1230. doi:10.1161/HYPERTENSIONAHA.120.14752

166. Poloni G, Calore M, Rigato I, Marras E, Minervini G, Mazzotti E, Lorenzon A, Li Mura IEA, Telatin A, Zara I, et al. A targeted nextgeneration gene panel reveals a novel heterozygous nonsense variant in the TP63 gene in patients with arrhythmogenic cardiomyopathy. Heart Rhythm. 2019;16(5):773-780. doi:10.1016/j.hrthm.2018.11.015

167. Brandt J, Warnke K, Jörgens S, Arolt V, Beer K, Domschke K, Haverkamp W, Kuhlmann SL, Müller-Nordhorn J, Rieckmann N, et al. Association of FKBP5 genotype with depressive symptoms in patients with coronary heart disease: a prospective study. J Neural Transm (Vienna). 2020;127(12):1651-1662. doi:10.1007/s00702-020-02243-6

168. Rudemiller N, Lund H, Jacob HJ, Geurts AM, Mattson DL; PhysGen Knockout Program. CD247 modulates blood pressure by altering Tlymphocyte infiltration in the kidney. Hypertension. 2014;63(3):559-564. doi:10.1161/HYPERTENSIONAHA.113.02191

169. Mishra S, Undrovinas NA, Maltsev VA, Reznikov V, Sabbah HN, Undrovinas A. Post-transcriptional silencing of SCN1B and SCN2B genes 
modulates late sodium current in cardiac myocytes from normal dogs and dogs with chronic heart failure. Am J Physiol Heart Circ Physiol. 2011;301(4):H1596-H1605. doi:10.1152/ajpheart.00948.2009

170. Gao J, Guo Y, Chen Y, Zhou J, Liu Y, Su P. Adeno-associated virus 9-mediated RNA interference targeting SOCS3 alleviates diastolic heart failure in rats. Gene. 2019;697:11-18. doi:10.1016/j.gene.2019.01.044

171. Wei Y, Zhu M, Corbalán-Campos J, Heyll K, Weber C, Schober A. Regulation of Csf1r and Bcl6 in macrophages mediates the stage-specific effects of microRNA-155 on atherosclerosis. Arterioscler Thromb Vasc Biol. 2015;35(4):796-803. doi:10.1161/ATVBAHA.114.304723

172. $\mathrm{Wu} \mathrm{N}$, Jin L, Cai J. Profiling and bioinformatics analyses reveal differential circular RNA expression in hypertensive patients. Clin Exp Hypertens. 2017;39(5):454-459. doi:10.1080/10641963.2016.1273944

173. Li Z, Chyr J, Jia Z, Wang L, Hu X, Wu X, Song C. Identification of Hub Genes Associated with Hypertension and Their Interaction with miRNA Based on Weighted Gene Coexpression Network Analysis (WGCNA) Analysis. Med Sci Monit. 2020;26:e923514. doi:10.12659/MSM.923514

174. Yang S, Gao Y, Liu G, Li J, Shi K, Du B, Si D, Yang P. The human ATF1 rs11169571 polymorphism increases essential hypertension risk through modifying miRNA binding. FEBS Lett. 2015;589(16):2087-2093. doi:10.1016/j.febslet.2015.06.029

175. Sun D, Li C, Liu J, Wang Z, Liu Y, Luo C, Chen Y, Wen S. Expression Profile of microRNAs in Hypertrophic Cardiomyopathy and Effects of microRNA-20 in Inducing Cardiomyocyte Hypertrophy Through Regulating Gene MFN2. DNA Cell Biol. 2019;38(8):796-807. doi:10.1089/dna.2019.4731

176. Larsen LH, Rose CS, Sparsø T, Overgaard J, Torekov SS, Grarup N, Jensen DP, Albrechtsen A, Andersen G, Ek J, et al. Genetic analysis of the estrogen-related receptor alpha and studies of association with obesity and type 2 diabetes. Int J Obes (Lond). 2007;31(2):365-370. doi:10.1038/sj.ijo.0803408

177. Choi JH, Choi SS, Kim ES, Jedrychowski MP, Yang YR, Jang HJ, Suh PG, Banks AS, Gygi SP, Spiegelman BM. Thrap3 docks on 


\section{phosphoserine 273 of PPAR $\gamma$ and controls diabetic gene programming. Genes Dev. 2014;28(21):2361-2369. doi:10.1101/gad.249367.114}

\section{Figures}

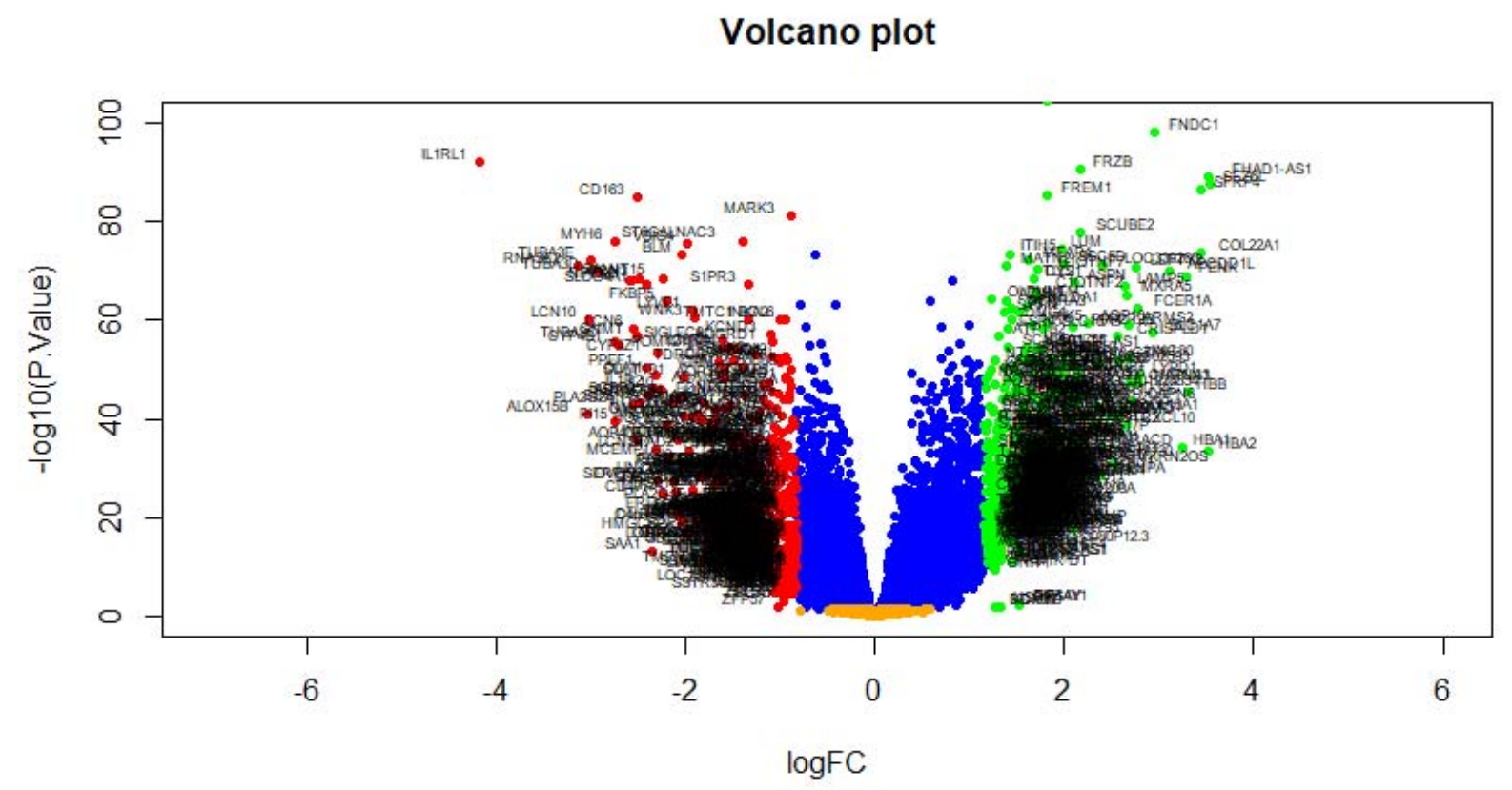

Fig. 1. Volcano plot of differentially expressed genes. Genes with a significant change of more than two-fold were selected. Green dot represented up regulated significant genes and red dot represented down regulated significant genes. 
bioRxiv preprint doi: https://doi.org/10.1101/2021.01.24.428028; this version posted January 26, 2021. The copyright holder for this preprint (which was not certified by peer review) is the author/funder. All rights reserved. No reuse allowed without permission.
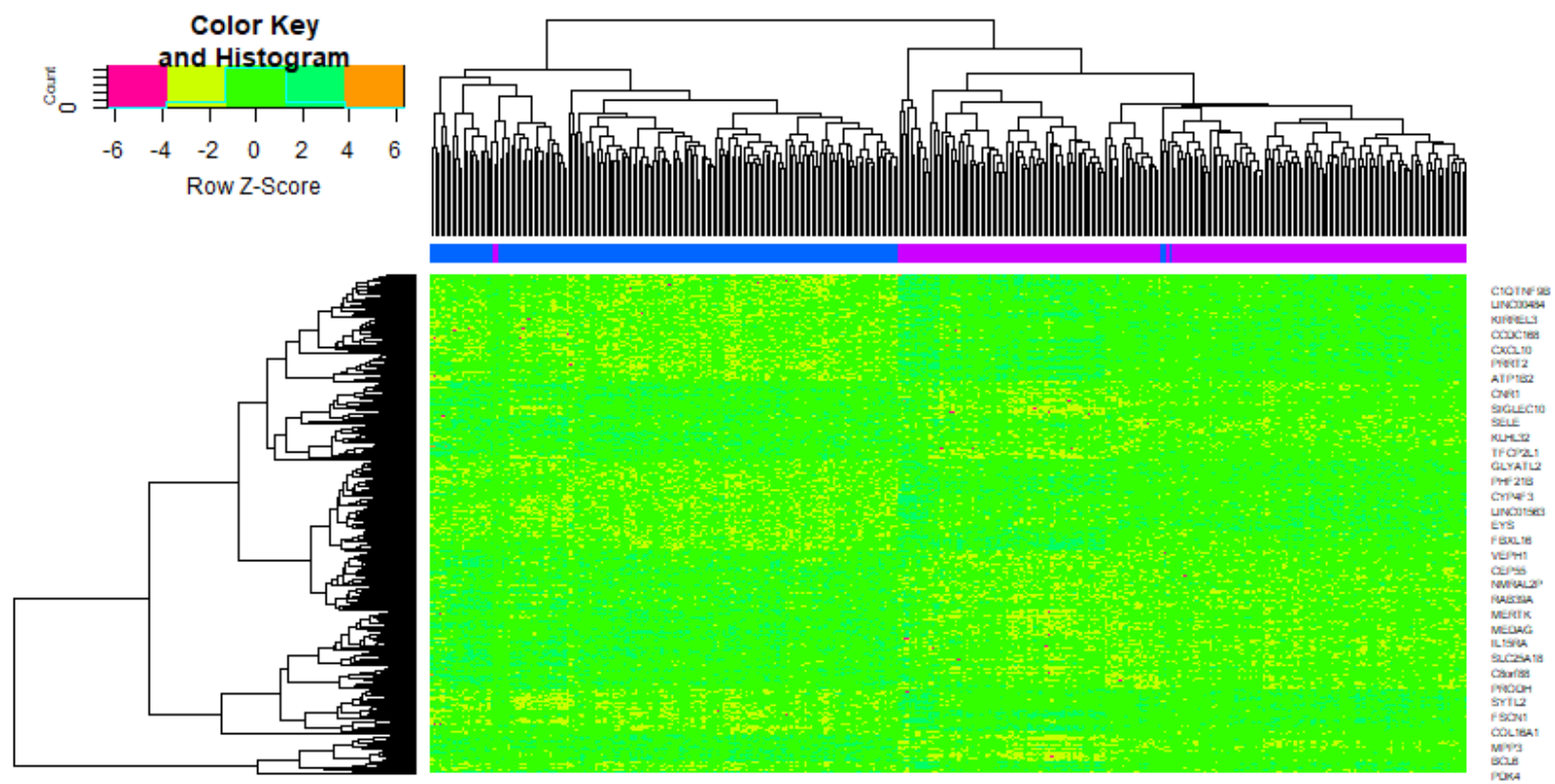

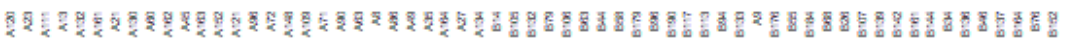

Fig. 2. Heat map of differentially expressed genes. Legend on the top left indicate log fold change of genes. (A1 A200 $=$ heart failure samples; B1 - B166 $=$ non heart failure samples)

A

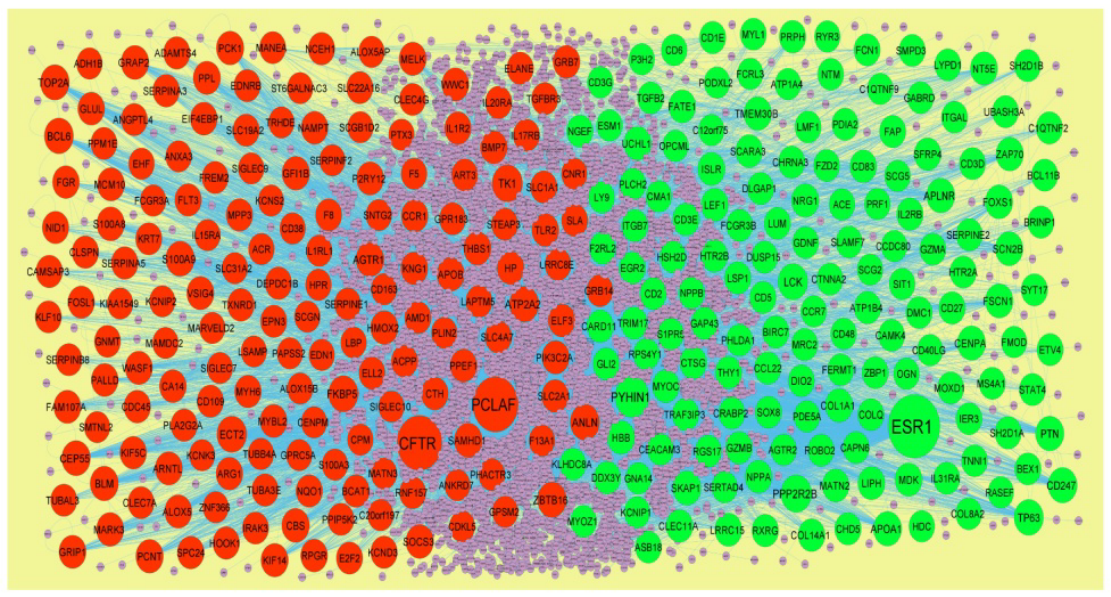

B

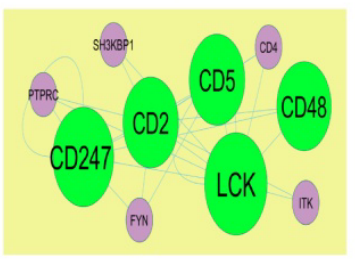

C

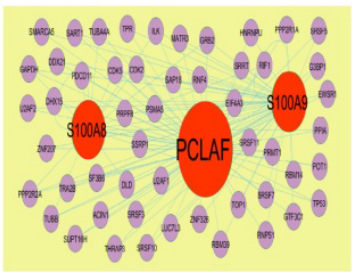

Fig. 3. PPI network and the most significant modules of DEGs. (A) The PPI network of DEGs was constructed using Cytoscape (B) The most significant module was obtained from PPI network with 4 nodes and 6 edges for up regulated genes (C) The most significant module was obtained from PPI network with 6 nodes and 10 edges for down regulated genes. Up regulated genes are marked in green; down regulated genes are marked in red 
bioRxiv preprint doi: https://doi.org/10.1101/2021.01.24.428028; this version posted January 26, 2021. The copyright holder for this preprint (which was not certified by peer review) is the author/funder. All rights reserved. No reuse allowed without permission.

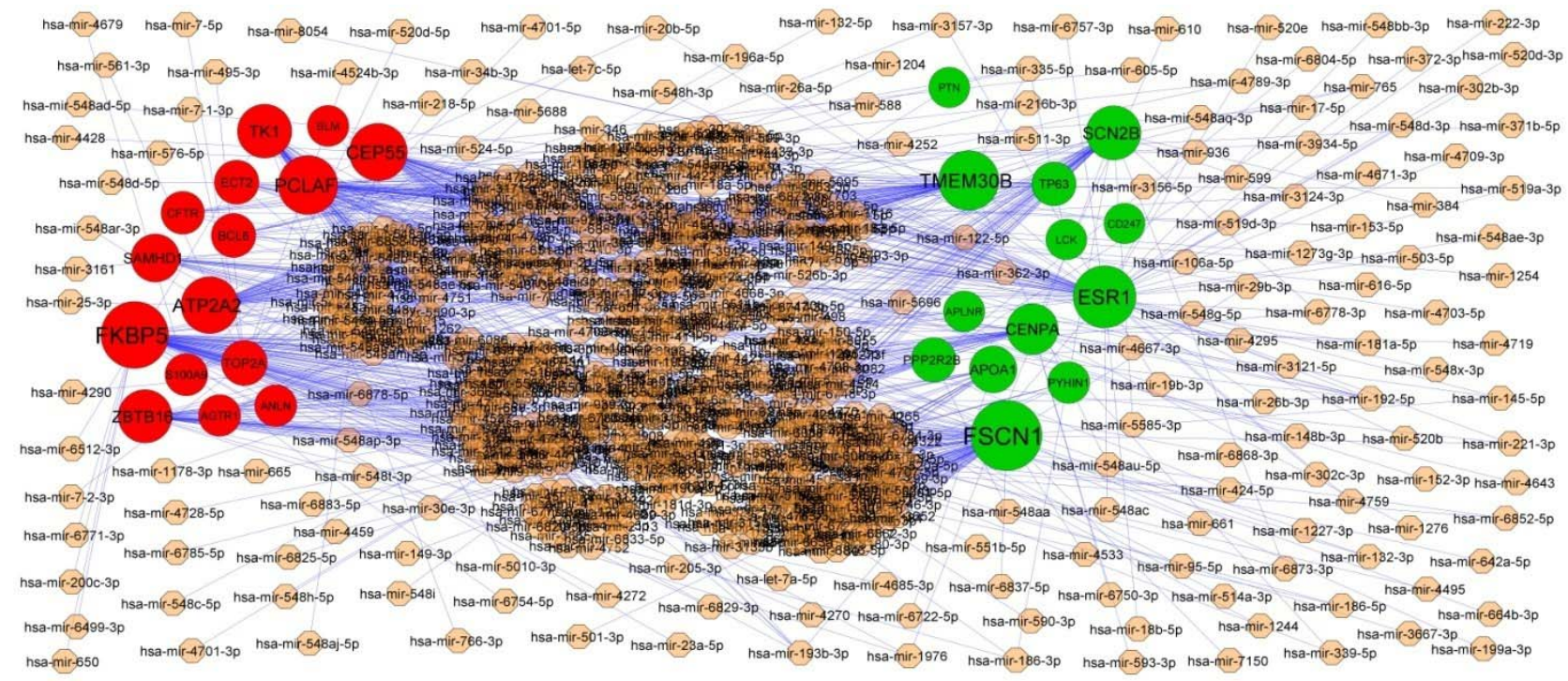

Fig. 4. Target gene - miRNA regulatory network between target genes. The light orange color diamond nodes represent the key miRNAs; up regulated genes are marked in green; down regulated genes are marked in red.

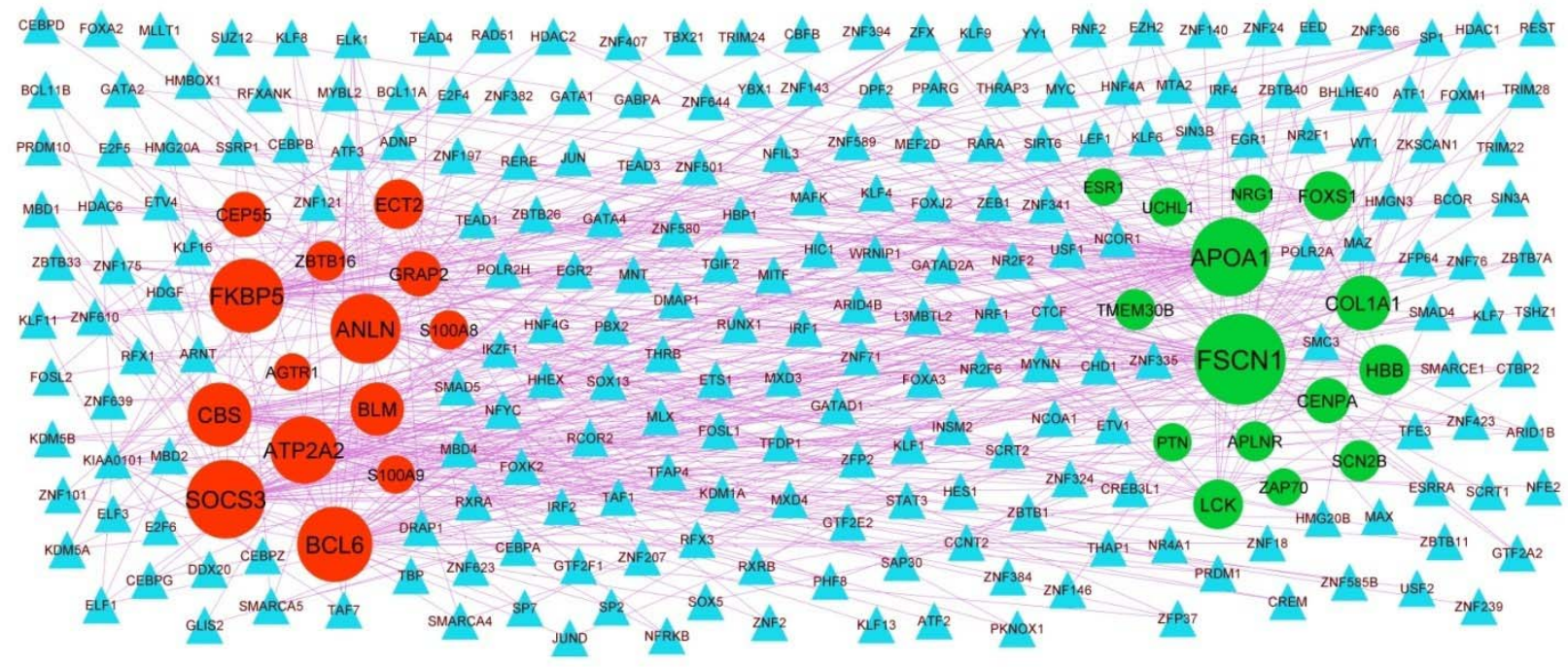

Fig. 5. Target gene - TF regulatory network between target genes. The sky blue color triangle nodes represent the key TFs; up regulated genes are marked in green; down regulated genes are marked in red. 

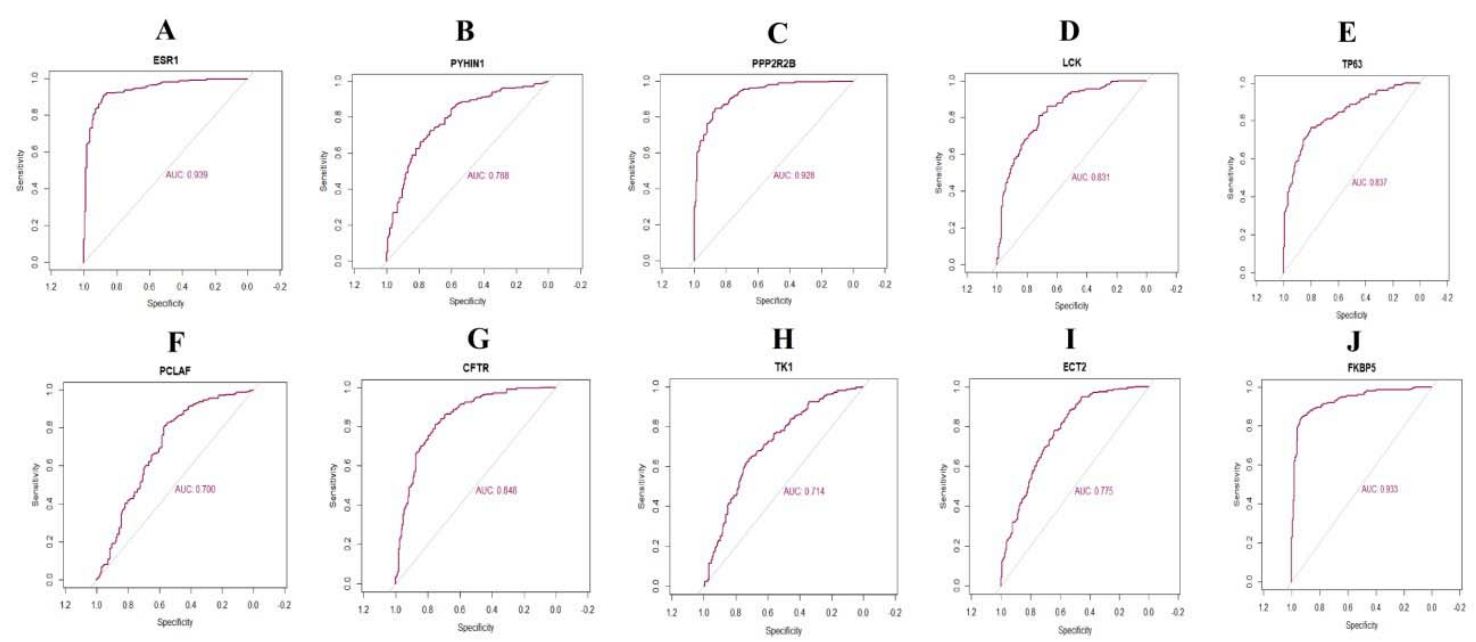

Fig. 6. ROC curve analyses of hub genes. A) ESR1 B) PYHIN1 C) PPP2R2B D) LCK E) TP63 F) PCLAF G) CFTR H) TK1 I) ECT2 J) FKBP5
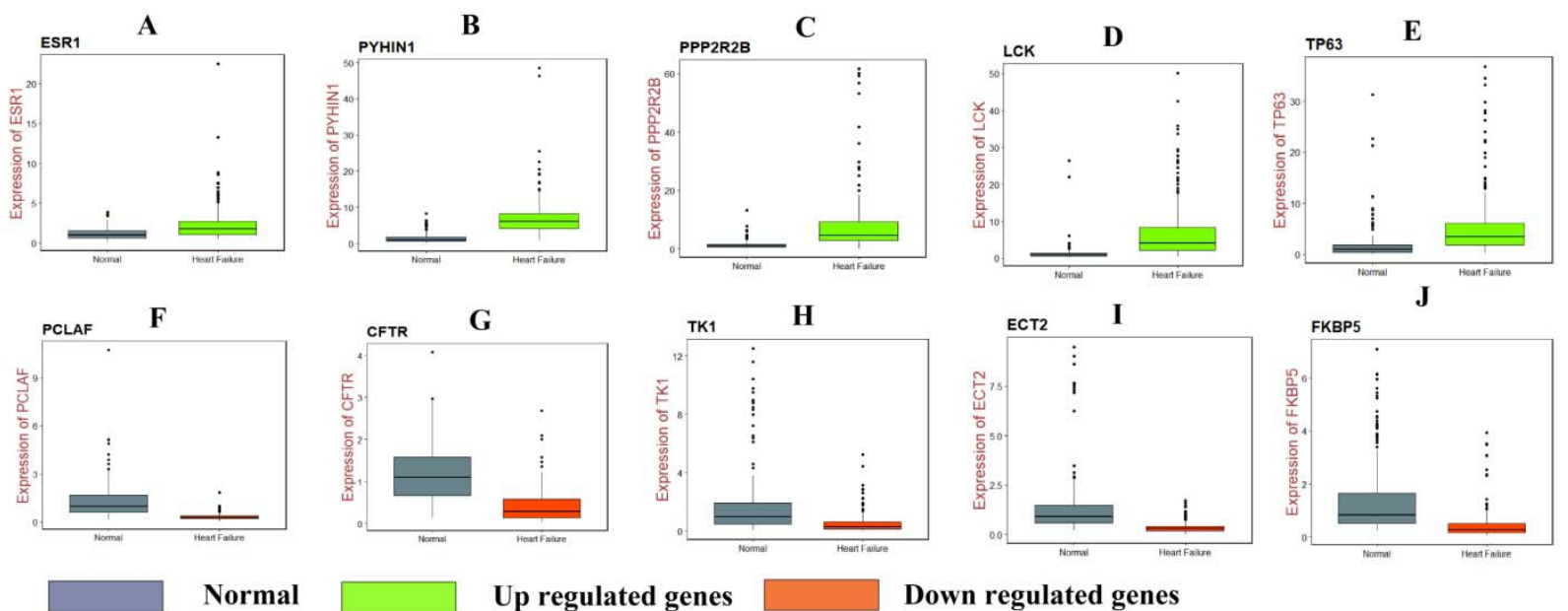

Fig. 7. RT-PCR analyses of hub genes. A) ESR1 B) PYHIN1 C) PPP2R2B D) LCK E) TP63 F) PCLAF G) CFTR H) TK1 I) ECT2 J) FKBP5 
<smiles>[R]C1([R])NCC(=O)N1c1nncc2ccc(C(=O)O[CH])cc12</smiles>

$\mathrm{R}$ :<smiles>Cc1ccc(Br)cc1</smiles><smiles>[AlH2]</smiles><smiles>Cc1ccc(F)cc1</smiles>

4<smiles>[R]C1([R])SCC(=O)N1c1nncc2ccc(C(=O)O[Z]([H])([H])[H])cc12</smiles>

HTZ1-17<smiles>NNc1nncc2ccccc12</smiles>

Hydrochlorothiazide (HTZ) standard<smiles>C=CC(C)=CC</smiles>

12<smiles>Cc1ccc(O)cc1</smiles>

13<smiles>COc1ccc(C)cc1</smiles><smiles>Cc1ccc(N)cc1</smiles><smiles>Cc1ccc(N(C)C)cc1</smiles><smiles>COc1cc(C)ccc1O</smiles>

Fig. 8. Structures of Designed Molecules

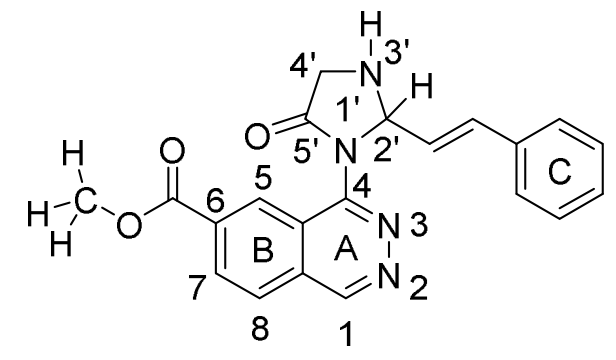

Methyl-4-(5'-oxo-2'-styrylimidazolidin-1'-yl)phthalazine-6-carboxylate

Fig. 9 Structure of active designed molecule of HIM11 

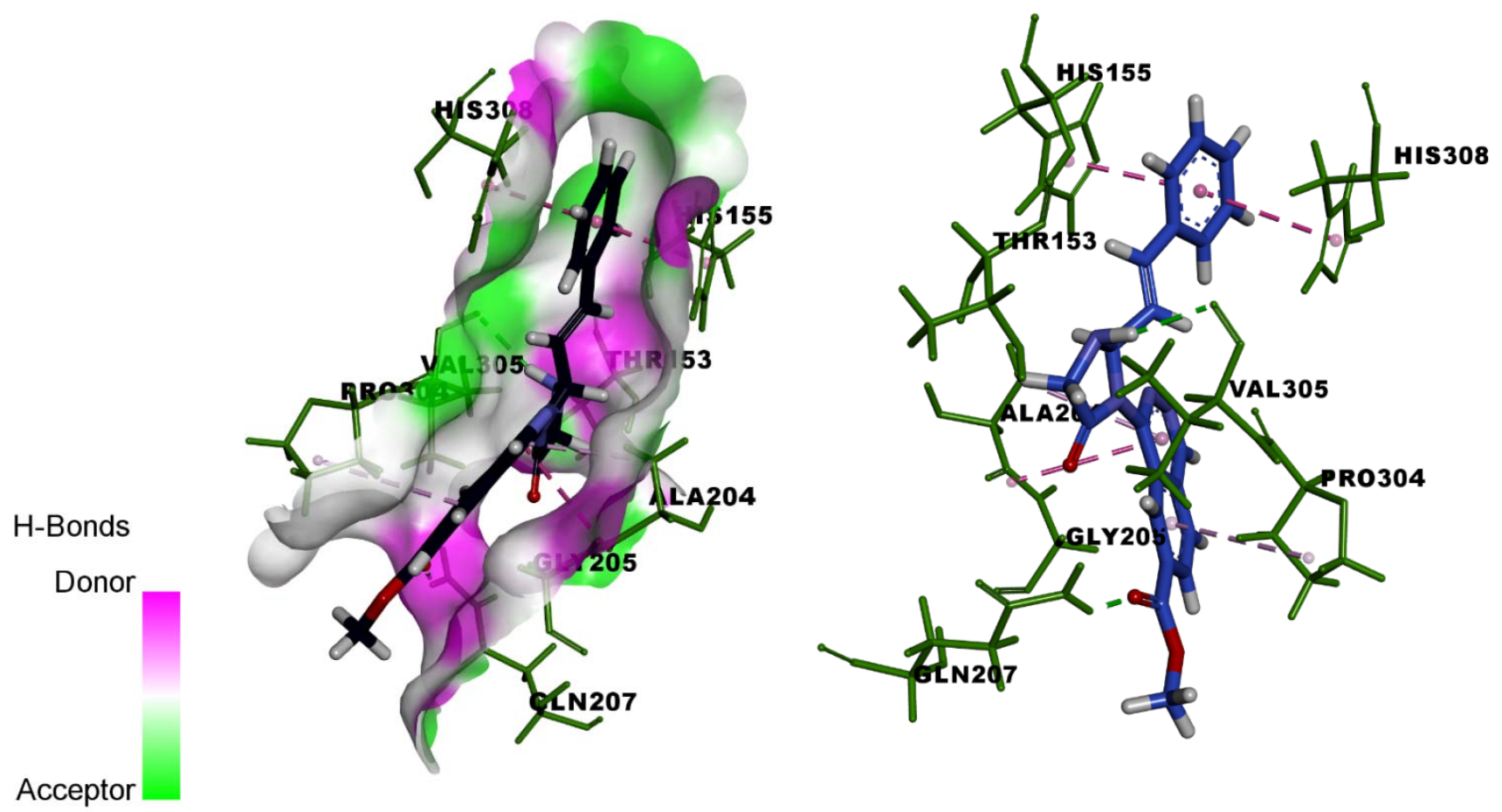

Fig.10. 3D Binding of Molecule HIM11 with 2HV7

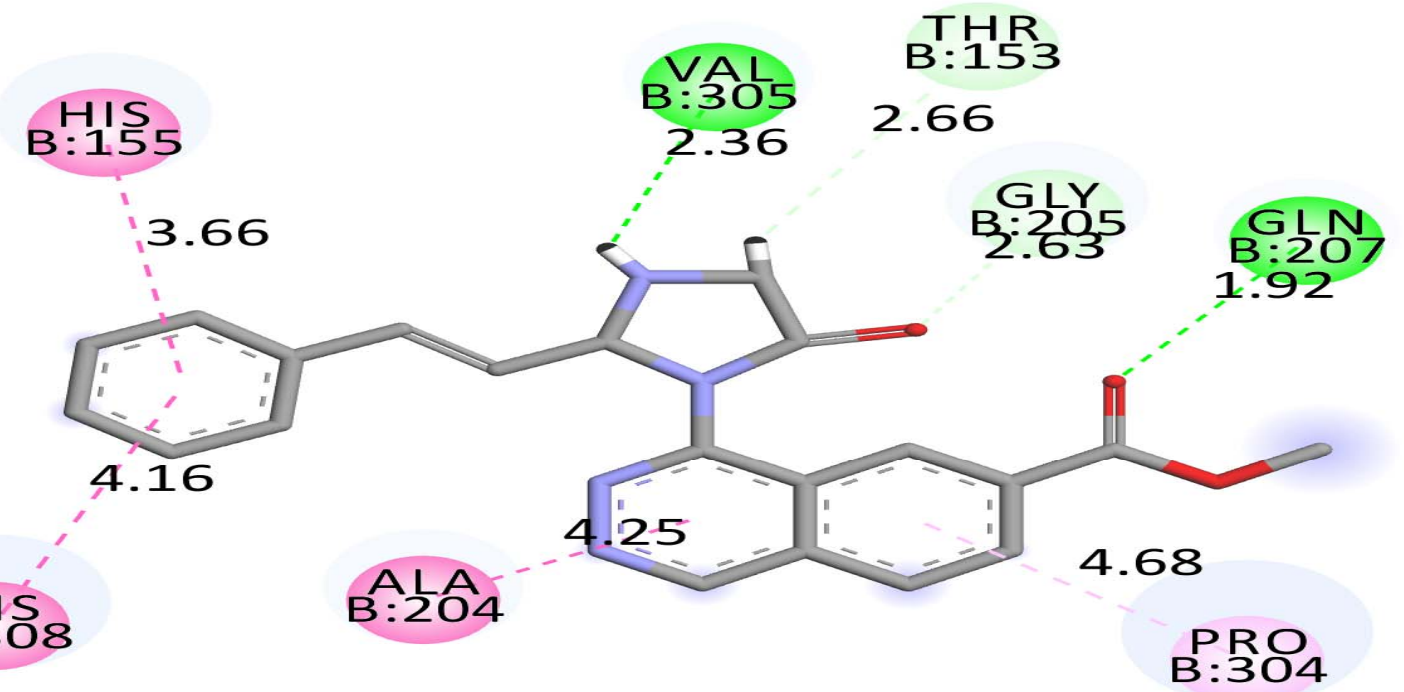

\section{Interactions}

Conventional Hydrogen Bond

Carbon Hydrogen Bond

Pi-Pi Stacked

Amide-Pi Stacked

Pi-Alkyl

Fig.11. 2D Binding of Molecule HIM11 with 2HV7 
Table 1 The sequences of primers for quantitative RT-PCR

\begin{tabular}{ccc}
\hline Genes & Forward Primers & Reverse Primers \\
\hline ESR1 & CCCACTCAACAGCGTGTCTC & CGTCGATTATCTGAATTTGGCCT \\
PYHIN1 & CCAAGCAACCGTCTCACAG & GCCGAGTCTGCTCTTTGGA \\
PPP2R2B & CCACACGGGAGAATTACTAGCG & TGTATTCACCCCTACGATGAACC \\
LCK & TGCCATTATCCCATAGTCCCA & GAGCCTTCGTAGGTAACCAGT \\
TP63 & GGACCAGCAGATTCAGAACGG & AGGACACGTCGAAACTGTGC \\
PCLAF & GACCAATATAAACTGTGGCGGG & CCAGGGTAAACAAGGAGACGTT \\
CFTR & AAAAGGCCAGCGTTGTCTCC & AAACATCGCCGAAGGGCATTA \\
TK1 & GGGCAGATCCAGGTGATTCTC & TGTAGCGAGTGTCTTTGGCATA \\
ECT2 & ACTACTGGGAGGACTAGCTTG & CACTCTTGTTCAATCTGAGGCA \\
FKBP5 & AATGGTGAGGAAACGCCGATG & TCGAGGGAATTTTAGGGAGACT \\
\hline
\end{tabular}

Table 2 The statistical metrics for key differentially expressed genes (DEGs)

\begin{tabular}{|c|c|c|c|c|c|c|}
\hline GeneSymbol & $\log \mathrm{FC}$ & pValue & adj.P.Val & tvalue & Regulation & Gene Name \\
\hline SEZ6L & 3.540921 & $3.57 \mathrm{E}-88$ & $1.24 \mathrm{E}-84$ & 26.74214 & $\mathrm{Up}$ & seizure related 6 homolog like \\
\hline HBA2 & 3.52441 & $2.69 \mathrm{E}-34$ & $1.06 \mathrm{E}-32$ & 13.57556 & Up & hemoglobin subunit alpha 2 \\
\hline FHAD1-AS1 & 3.514827 & $9.64 \mathrm{E}-90$ & $4.01 \mathrm{E}-86$ & 27.14088 & Up & FHAD1 antisense RNA 1 \\
\hline COL22A1 & 3.442684 & $3.27 \mathrm{E}-74$ & $4 \mathrm{E}-71$ & 23.26846 & Up & collagen type XXII alpha 1 chain \\
\hline SFRP4 & 3.439595 & $3.23 \mathrm{E}-87$ & $9.58 \mathrm{E}-84$ & 26.49986 & Up & secreted frizzled related protein 4 \\
\hline HBB & 3.311845 & 4.49E-46 & $4.34 \mathrm{E}-44$ & 16.48352 & Up & hemoglobin subunit beta \\
\hline PENK & 3.292908 & $1.23 \mathrm{E}-69$ & $8.22 \mathrm{E}-67$ & 22.15479 & Up & proenkephalin \\
\hline HBA1 & 3.239241 & 7.91E-35 & $3.22 \mathrm{E}-33$ & 13.71027 & Up & hemoglobin subunit alpha 1 \\
\hline APCDD1L & 3.102854 & $1.43 \mathrm{E}-70$ & $9.91 \mathrm{E}-68$ & 22.38121 & Up & APC down-regulated 1 like \\
\hline FNDC1 & 2.952 & 8.2E-99 & $8.53 \mathrm{E}-95$ & 29.4879 & Up & fibronectin type III domain containing 1 \\
\hline SLC1A7 & 2.935446 & $3.45 \mathrm{E}-58$ & $9.31 \mathrm{E}-56$ & 19.39718 & Up & solute carrier family 1 member 7 \\
\hline LYPD1 & 2.786956 & $1.94 \mathrm{E}-49$ & $2.57 \mathrm{E}-47$ & 17.29603 & Up & LY6/PLAUR domain containing 1 \\
\hline FCER1A & 2.775152 & $5.58 \mathrm{E}-63$ & $2.11 \mathrm{E}-60$ & 20.5475 & Up & $\mathrm{Fc}$ fragment of $\mathrm{IgE}$ receptor Ia \\
\hline HAPLN1 & 2.766834 & $6.66 \mathrm{E}-48$ & 7.6E-46 & 16.92589 & Up & hyaluronan and proteoglycan link protein 1 \\
\hline LEFTY2 & 2.748568 & $3.27 \mathrm{E}-71$ & $2.52 \mathrm{E}-68$ & 22.53707 & Up & left-right determination factor 2 \\
\hline CAPN6 & 2.718519 & $3.14 \mathrm{E}-44$ & $2.57 \mathrm{E}-42$ & 16.03574 & Up & calpain 6 \\
\hline UNC80 & 2.706223 & $6.44 \mathrm{E}-53$ & $1.21 \mathrm{E}-50$ & 18.13271 & Up & unc-80 homolog, NALCN channel complex subunit \\
\hline CHRNA3 & 2.691289 & 3.77E-48 & 4.53E-46 & 16.98549 & Up & cholinergic receptor nicotinic alpha 3 subunit \\
\hline ARMS2 & 2.677012 & 7.71E-60 & $2.39 \mathrm{E}-57$ & 19.79325 & Up & age-related maculopathy susceptibility 2 \\
\hline MXRA5 & 2.665146 & 7.01E-66 & $3.31 \mathrm{E}-63$ & 21.24615 & Up & matrix remodeling associated 5 \\
\hline CXCL10 & 2.648986 & $1.88 \mathrm{E}-39$ & $1.06 \mathrm{E}-37$ & 14.8648 & Up & $\mathrm{C}-\mathrm{X}-\mathrm{C}$ motif chemokine ligand 10 \\
\hline LAMP5 & 2.634422 & $1.79 \mathrm{E}-67$ & $8.84 \mathrm{E}-65$ & 21.63104 & Up & lysosomal associated membrane protein family member 5 \\
\hline GZMH & 2.585101 & $1.39 \mathrm{E}-52$ & $2.54 \mathrm{E}-50$ & 18.05238 & Up & granzyme $\mathrm{H}$ \\
\hline COL10A1 & 2.58157 & $3.89 \mathrm{E}-42$ & $2.71 \mathrm{E}-40$ & 15.52492 & Up & collagen type $X$ alpha 1 chain \\
\hline TNMD & 2.561494 & $2.35 \mathrm{E}-41$ & $1.55 \mathrm{E}-39$ & 15.3336 & Up & tenomodulin \\
\hline CRISPLD1 & 2.551697 & $1.75 \mathrm{E}-57$ & 4.48E-55 & 19.22821 & Up & cysteine rich secretory protein LCCL domain containing 1 \\
\hline MKRN2OS & 2.518052 & $1.81 \mathrm{E}-31$ & $5.81 \mathrm{E}-30$ & 12.85257 & Up & MKRN2 opposite strand \\
\hline CMA1 & 2.49186 & $2.56 \mathrm{E}-41$ & $1.68 \mathrm{E}-39$ & 15.32454 & Up & chymase 1 \\
\hline
\end{tabular}




\begin{tabular}{|c|c|c|c|c|c|c|}
\hline CRACD & 2.409728 & 7.61E-35 & $3.1 \mathrm{E}-33$ & 13.71447 & Up & capping protein inhibiting regulator of actin dynamics \\
\hline LOC 339260 & 2.40851 & $9.48 \mathrm{E}-72$ & $8.21 \mathrm{E}-69$ & 22.66783 & Up & uncharacterized LOC339260 \\
\hline CENPA & 2.378802 & 2.87E-29 & $7.86 \mathrm{E}-28$ & 12.27893 & Up & centromere protein $\mathrm{A}$ \\
\hline LINC02593 & 2.357621 & $6.61 \mathrm{E}-52$ & $1.09 \mathrm{E}-49$ & 17.8899 & Up & long intergenic non-protein coding RNA 2593 \\
\hline LRRC55 & 2.35454 & $4.34 \mathrm{E}-43$ & $3.3 \mathrm{E}-41$ & 15.75782 & Up & leucine rich repeat containing 55 \\
\hline AGTR2 & 2.346789 & $3.04 \mathrm{E}-39$ & $1.69 \mathrm{E}-37$ & 14.81336 & Up & angiotensin II receptor type 2 \\
\hline GLIS1 & 2.270732 & $1.08 \mathrm{E}-41$ & 7.24E-40 & 15.41668 & Up & GLIS family zinc finger 1 \\
\hline AQP10 & 2.238434 & $5.77 \mathrm{E}-60$ & $1.82 \mathrm{E}-57$ & 19.82339 & Up & aquaporin 10 \\
\hline TMEM130 & 2.225534 & $1.08 \mathrm{E}-32$ & $3.78 \mathrm{E}-31$ & 13.16693 & Up & transmembrane protein 130 \\
\hline CXCL11 & 2.22214 & $3.56 \mathrm{E}-30$ & $1.03 \mathrm{E}-28$ & 12.51639 & Up & $\mathrm{C}-\mathrm{X}-\mathrm{C}$ motif chemokine ligand 11 \\
\hline NKG7 & 2.203903 & $2.69 \mathrm{E}-41$ & $1.75 \mathrm{E}-39$ & 15.3192 & Up & natural killer cell granule protein 7 \\
\hline ESM1 & 2.203875 & $1.56 \mathrm{E}-35$ & $6.67 \mathrm{E}-34$ & 13.88776 & Up & endothelial cell specific molecule 1 \\
\hline NPPA & 2.194101 & $5.13 \mathrm{E}-29$ & $1.38 \mathrm{E}-27$ & 12.21264 & Up & natriuretic peptide $\mathrm{A}$ \\
\hline FRZB & 2.175346 & 4.1E-91 & $2.13 \mathrm{E}-87$ & 27.49106 & Up & $\begin{array}{l}\text { frizzled related protein } \\
\text { signal peptide, CUB domain and EGF like domain }\end{array}$ \\
\hline SCUBE2 & 2.170552 & $1.48 \mathrm{E}-78$ & $2.8 \mathrm{E}-75$ & 24.33596 & Up & containing 2 \\
\hline TGFB2-AS1 & 2.167994 & $1.32 \mathrm{E}-41$ & $8.84 \mathrm{E}-40$ & 15.39479 & Up & TGFB2 antisense RNA 1 (head to head) \\
\hline ANKRD34C & 2.159555 & $2.72 \mathrm{E}-45$ & $2.48 \mathrm{E}-43$ & 16.29382 & Up & ankyrin repeat domain $34 \mathrm{C}$ \\
\hline ZNF365 & 2.146095 & $9.54 \mathrm{E}-49$ & $1.2 \mathrm{E}-46$ & 17.1295 & Up & zinc finger protein 365 \\
\hline KCNIP1 & 2.140052 & $9.06 \mathrm{E}-50$ & $1.24 \mathrm{E}-47$ & 17.37589 & Up & potassium voltage-gated channel interacting protein 1 \\
\hline $\mathrm{CD} 1 \mathrm{C}$ & 2.134028 & $3.98 \mathrm{E}-44$ & $3.25 \mathrm{E}-42$ & 16.01054 & Up & CD1c molecule \\
\hline ASPN & 2.117196 & $3.21 \mathrm{E}-68$ & $1.71 \mathrm{E}-65$ & 21.8113 & Up & asporin \\
\hline PPP2R2B & 2.092908 & $2.1 \mathrm{E}-59$ & $6.14 \mathrm{E}-57$ & 19.68888 & Up & protein phosphatase 2 regulatory subunit Bbeta \\
\hline NPPB & 2.091998 & $1.57 \mathrm{E}-18$ & $1.74 \mathrm{E}-17$ & 9.274014 & $\mathrm{Up}$ & natriuretic peptide $B$ \\
\hline HRK & 2.091711 & $4.32 \mathrm{E}-44$ & $3.5 \mathrm{E}-42$ & 16.00206 & Up & harakiri, BCL2 interacting protein \\
\hline LOC101928834 & 2.091398 & $4.58 \mathrm{E}-47$ & $4.96 \mathrm{E}-45$ & 16.72358 & Up & uncharacterized LOC101928834 \\
\hline GZMB & 2.085361 & $2.05 \mathrm{E}-40$ & $1.25 \mathrm{E}-38$ & 15.10213 & Up & granzyme B \\
\hline RTL3 & 2.083673 & $1.52 \mathrm{E}-53$ & 3.09E-51 & 18.28344 & Up & retrotransposon Gag like 3 \\
\hline CX3CR1 & 2.069035 & $3.8 \mathrm{E}-45$ & $3.42 \mathrm{E}-43$ & 16.25861 & Up & $\mathrm{C}-\mathrm{X} 3-\mathrm{C}$ motif chemokine receptor 1 \\
\hline COMP & 2.051651 & $1.51 \mathrm{E}-19$ & $1.82 \mathrm{E}-18$ & 9.579662 & Up & cartilage oligomeric matrix protein \\
\hline CTSG & 2.049972 & $5.94 \mathrm{E}-37$ & $2.83 \mathrm{E}-35$ & 14.24398 & Up & cathepsin $\mathrm{G}$ \\
\hline FAM180B & 2.034044 & 4.11E-41 & $2.64 \mathrm{E}-39$ & 15.27385 & Up & family with sequence similarity 180 member B \\
\hline MDK & 2.023427 & $5.33 \mathrm{E}-46$ & $5.08 \mathrm{E}-44$ & 16.46554 & Up & midkine \\
\hline NFIA-AS2 & 2.011983 & $1.41 \mathrm{E}-51$ & $2.25 \mathrm{E}-49$ & 17.81082 & Up & NFIA antisense RNA 2 \\
\hline FATE1 & 2.011836 & $5.31 \mathrm{E}-38$ & $2.71 \mathrm{E}-36$ & 14.50539 & Up & $\begin{array}{c}\text { fetal and adult testis expressed } 1 \\
\text { protein kinase AMP-activated non-catalytic subunit }\end{array}$ \\
\hline PRKAG3 & 2.002215 & 4.44E-48 & $5.27 \mathrm{E}-46$ & 16.96846 & Up & gamma 3 \\
\hline COL9A1 & 2.001739 & $5.6 \mathrm{E}-52$ & $9.31 \mathrm{E}-50$ & 17.90721 & Up & $\begin{array}{l}\text { collagen type IX alpha } 1 \text { chain } \\
\text { scavenger receptor cysteine rich family member with } 5\end{array}$ \\
\hline SSC5D & 1.998905 & $6.1 \mathrm{E}-72$ & $5.51 \mathrm{E}-69$ & 22.71447 & Up & domains \\
\hline ACE & 1.99576 & $1.54 \mathrm{E}-53$ & $3.12 \mathrm{E}-51$ & 18.28159 & Up & angiotensin I converting enzyme \\
\hline GDF6 & 1.994884 & $6.98 \mathrm{E}-50$ & $9.74 \mathrm{E}-48$ & 17.40311 & Up & growth differentiation factor 6 \\
\hline SHISA2 & 1.989108 & $1.04 \mathrm{E}-43$ & 8.27E-42 & 15.90886 & Up & shisa family member 2 \\
\hline$X G$ & 1.986441 & $2.84 \mathrm{E}-34$ & $1.11 \mathrm{E}-32$ & 13.56967 & Up & Xg glycoprotein (Xg blood group) \\
\hline LUM & 1.96673 & 4.91E-75 & $6.81 \mathrm{E}-72$ & 23.47008 & Up & lumican \\
\hline
\end{tabular}




\begin{tabular}{|c|c|c|c|c|c|c|}
\hline RGS4 & 1.958569 & $2.81 \mathrm{E}-47$ & $3.09 \mathrm{E}-45$ & 16.77466 & Up & regulator of G protein signaling 4 \\
\hline FCGR3B & 1.945296 & $1.19 \mathrm{E}-31$ & $3.87 \mathrm{E}-30$ & 12.89978 & Up & Fc fragment of IgG receptor IIIb \\
\hline $\mathrm{HSH} 2 \mathrm{D}$ & 1.94243 & $6.51 \mathrm{E}-46$ & $6.15 \mathrm{E}-44$ & 16.44441 & Up & hematopoietic $\mathrm{SH} 2$ domain containing \\
\hline WNT9A & 1.941347 & 4.74E-36 & $2.09 \mathrm{E}-34$ & 14.018 & Up & Wnt family member $9 \mathrm{~A}$ \\
\hline SAMD11 & 1.937898 & $2.66 \mathrm{E}-28$ & $6.76 \mathrm{E}-27$ & 12.02359 & Up & sterile alpha motif domain containing 11 \\
\hline LTB & 1.919135 & $1.96 \mathrm{E}-30$ & $5.77 \mathrm{E}-29$ & 12.5841 & Up & lymphotoxin beta \\
\hline CTSW & 1.916821 & $3.18 \mathrm{E}-37$ & $1.55 \mathrm{E}-35$ & 14.31185 & Up & cathepsin W \\
\hline ARMC4 & 1.913783 & $2.91 \mathrm{E}-50$ & $4.17 \mathrm{E}-48$ & 17.49459 & Up & armadillo repeat containing 4 \\
\hline ATP1B4 & 1.909761 & $8.05 \mathrm{E}-19$ & $9.12 \mathrm{E}-18$ & 9.36208 & Up & ATPase $\mathrm{Na}+\mathrm{K}+$ transporting family member beta 4 \\
\hline TNNI1 & 1.901808 & $5.89 \mathrm{E}-21$ & $8.11 \mathrm{E}-20$ & 9.993524 & Up & troponin I1, slow skeletal type \\
\hline CYP4F3 & 1.901148 & $4.61 \mathrm{E}-32$ & $1.55 \mathrm{E}-30$ & 13.0053 & Up & cytochrome P450 family 4 subfamily F member 3 \\
\hline RYR3 & 1.890853 & 2.04E-46 & 2.07E-44 & 16.56646 & Up & ryanodine receptor 3 \\
\hline NDP & 1.884805 & $7.22 \mathrm{E}-39$ & $3.91 \mathrm{E}-37$ & 14.72038 & Up & norrincystine knot growth factor NDP \\
\hline SLAMF7 & 1.880253 & $9.55 \mathrm{E}-37$ & $4.48 \mathrm{E}-35$ & 14.1924 & Up & SLAM family member 7 \\
\hline PI16 & 1.873783 & $2.52 \mathrm{E}-45$ & $2.31 \mathrm{E}-43$ & 16.30173 & Up & peptidase inhibitor 16 \\
\hline OGN & 1.873487 & $6.47 \mathrm{E}-51$ & 9.81E-49 & 17.65171 & Up & osteoglycin \\
\hline $\mathrm{BIRC7}$ & 1.867331 & $1.22 \mathrm{E}-20$ & $1.61 \mathrm{E}-19$ & 9.901493 & Up & baculoviral IAP repeat containing 7 \\
\hline APLNR & 1.85994 & $8.58 \mathrm{E}-53$ & $1.59 \mathrm{E}-50$ & 18.10284 & Up & apelin receptor \\
\hline ADAM18 & 1.857904 & $1.11 \mathrm{E}-25$ & $2.24 \mathrm{E}-24$ & 11.31964 & Up & ADAM metallopeptidase domain 18 \\
\hline OASL & 1.857886 & $9.34 \mathrm{E}-50$ & $1.27 \mathrm{E}-47$ & 17.3727 & Up & 2'-5'-oligoadenylate synthetase like \\
\hline CREG2 & 1.844542 & $3.04 \mathrm{E}-37$ & $1.49 \mathrm{E}-35$ & 14.31649 & Up & cellular repressor of E1A stimulated genes 2 \\
\hline SIGLEC17P & 1.840393 & $6.23 \mathrm{E}-38$ & $3.17 \mathrm{E}-36$ & 14.48798 & Up & sialic acid binding Ig like lectin 17, pseudogene \\
\hline LINC00861 & 1.837563 & $1.09 \mathrm{E}-39$ & $6.29 \mathrm{E}-38$ & 14.92381 & Up & long intergenic non-protein coding RNA 861 \\
\hline GPR68 & 1.834869 & $2.31 \mathrm{E}-32$ & $7.86 \mathrm{E}-31$ & 13.0825 & Up & G protein-coupled receptor 68 \\
\hline ISLR & 1.831354 & $1.03 \mathrm{E}-49$ & $1.39 \mathrm{E}-47$ & 17.36275 & Up & immunoglobulin superfamily containing leucine rich repeat \\
\hline AK5 & 1.822757 & $3.92 \mathrm{E}-60$ & $1.25 \mathrm{E}-57$ & 19.8637 & Up & adenylate kinase 5 \\
\hline FREM1 & 1.822486 & $3.96 \mathrm{E}-86$ & $1.03 \mathrm{E}-82$ & 26.22491 & Up & FRAS1 related extracellular matrix 1 \\
\hline SYTL5 & 1.818907 & $5.97 \mathrm{E}-20$ & $7.48 \mathrm{E}-19$ & 9.698984 & Up & synaptotagmin like 5 \\
\hline STAT4 & 1.815386 & $1.94 \mathrm{E}-40$ & $1.18 \mathrm{E}-38$ & 15.10812 & Up & signal transducer and activator of transcription 4 \\
\hline SMOC2 & 1.808707 & $3.5 \mathrm{E}-105$ & 7.3E-101 & 31.18302 & Up & SPARC related modular calcium binding 2 \\
\hline SAMD3 & 1.804067 & $4.45 \mathrm{E}-45$ & $3.97 \mathrm{E}-43$ & 16.2419 & Up & sterile alpha motif domain containing 3 \\
\hline VGLL2 & 1.802895 & $5.36 \mathrm{E}-18$ & $5.67 \mathrm{E}-17$ & 9.111967 & Up & vestigial like family member 2 \\
\hline LINC01563 & 1.792042 & $1.87 \mathrm{E}-40$ & $1.15 \mathrm{E}-38$ & 15.11196 & Up & $\begin{array}{l}\text { long intergenic non-protein coding RNA } 1563 \\
\text { potassium two pore domain channel subfamily K member }\end{array}$ \\
\hline KCNK17 & 1.791993 & 4.93E-29 & $1.32 \mathrm{E}-27$ & 12.21731 & Up & 17 \\
\hline TMEM119 & 1.786136 & $3.08 \mathrm{E}-34$ & $1.2 \mathrm{E}-32$ & 13.5608 & Up & transmembrane protein 119 \\
\hline SLC16A9 & 1.78355 & 4.41E-59 & $1.24 \mathrm{E}-56$ & 19.61146 & Up & solute carrier family 16 member 9 \\
\hline GZMA & 1.780273 & $7.61 \mathrm{E}-43$ & $5.69 \mathrm{E}-41$ & 15.69824 & Up & granzyme A \\
\hline OGDHL & 1.772273 & $6.58 \mathrm{E}-45$ & $5.8 \mathrm{E}-43$ & 16.20069 & Up & oxoglutarate dehydrogenase like \\
\hline ATP1A4 & 1.772266 & $1.92 \mathrm{E}-44$ & $1.6 \mathrm{E}-42$ & 16.08796 & Up & ATPase $\mathrm{Na}+/ \mathrm{K}+$ transporting subunit alpha 4 \\
\hline GAP43 & 1.770722 & $1.3 \mathrm{E}-26$ & $2.84 \mathrm{E}-25$ & 11.57199 & Up & growth associated protein 43 \\
\hline RASEF & 1.767816 & $9.28 \mathrm{E}-35$ & $3.77 \mathrm{E}-33$ & 13.69272 & Up & RAS and EF-hand domain containing \\
\hline CHD5 & 1.767757 & $3.25 \mathrm{E}-36$ & $1.46 \mathrm{E}-34$ & 14.05911 & Up & chromodomain helicase DNA binding protein 5 \\
\hline
\end{tabular}




\begin{tabular}{|c|c|c|c|c|c|c|}
\hline PRF1 & 1.765387 & $2.68 \mathrm{E}-42$ & $1.88 \mathrm{E}-40$ & 15.56459 & Up & perforin 1 \\
\hline OXER1 & 1.757588 & $1.14 \mathrm{E}-51$ & $1.86 \mathrm{E}-49$ & 17.8326 & Up & oxoeicosanoid receptor 1 \\
\hline LSP1 & 1.755261 & $7.18 \mathrm{E}-55$ & $1.57 \mathrm{E}-52$ & 18.6014 & Up & lymphocyte specific protein 1 \\
\hline NRXN2 & 1.753031 & $1.35 \mathrm{E}-39$ & $7.71 \mathrm{E}-38$ & 14.90069 & Up & neurexin 2 \\
\hline CXCL9 & 1.752192 & $1.37 \mathrm{E}-20$ & $1.81 \mathrm{E}-19$ & 9.886423 & Up & $\mathrm{C}-\mathrm{X}-\mathrm{C}$ motif chemokine ligand 9 \\
\hline MYL1 & 1.741306 & $3.26 \mathrm{E}-23$ & $5.46 \mathrm{E}-22$ & 10.6376 & Up & myosin light chain 1 \\
\hline DBH-AS1 & 1.740319 & $2.27 \mathrm{E}-43$ & $1.76 \mathrm{E}-41$ & 15.82628 & Up & DBH antisense RNA 1 \\
\hline CERS1 & 1.737417 & 7.6E-28 & $1.84 \mathrm{E}-26$ & 11.90259 & Up & ceramide synthase 1 \\
\hline OPCML & 1.7359 & $8.75 \mathrm{E}-40$ & $5.11 \mathrm{E}-38$ & 14.94691 & Up & opioid binding protein/cell adhesion molecule like \\
\hline APOA1 & 1.735578 & $1.38 \mathrm{E}-27$ & $3.24 \mathrm{E}-26$ & 11.83363 & Up & apolipoprotein A1 \\
\hline STAB2 & 1.73447 & $1.05 \mathrm{E}-26$ & $2.31 \mathrm{E}-25$ & 11.5969 & Up & stabilin 2 \\
\hline C16orf89 & 1.731539 & $1.26 \mathrm{E}-40$ & $7.83 \mathrm{E}-39$ & 15.15416 & Up & chromosome 16 open reading frame 89 \\
\hline LRRC15 & 1.731261 & $5.75 \mathrm{E}-30$ & $1.65 \mathrm{E}-28$ & 12.46207 & Up & leucine rich repeat containing 15 \\
\hline C1QTNF7 & 1.725627 & $7.28 \mathrm{E}-71$ & $5.4 \mathrm{E}-68$ & 22.45257 & Up & $\mathrm{C} 1 \mathrm{q}$ and TNF related 7 \\
\hline TMEM200A & 1.7209 & $4.9 \mathrm{E}-25$ & $9.41 \mathrm{E}-24$ & 11.14357 & Up & transmembrane protein $200 \mathrm{~A}$ \\
\hline LHCGR & 1.716273 & $2.18 \mathrm{E}-22$ & $3.38 \mathrm{E}-21$ & 10.40422 & Up & luteinizing hormone/choriogonadotropin receptor \\
\hline PRSS35 & 1.713597 & 7.99E-34 & $3.01 \mathrm{E}-32$ & 13.45573 & Up & serine protease 35 \\
\hline S1PR5 & 1.710201 & $5.13 \mathrm{E}-30$ & $1.48 \mathrm{E}-28$ & 12.47513 & Up & sphingosine-1-phosphate receptor 5 \\
\hline NTM & 1.707182 & $4.2 \mathrm{E}-65$ & $1.94 \mathrm{E}-62$ & 21.05873 & Up & neurotrimin \\
\hline FCRL3 & 1.703236 & $3.65 \mathrm{E}-29$ & $9.88 \mathrm{E}-28$ & 12.25172 & Up & Fc receptor like 3 \\
\hline KLHDC8A & 1.697472 & $3.11 \mathrm{E}-36$ & $1.4 \mathrm{E}-34$ & 14.06389 & Up & kelch domain containing $8 \mathrm{~A}$ \\
\hline MELTF-AS1 & 1.696996 & $1.04 \mathrm{E}-54$ & $2.24 \mathrm{E}-52$ & 18.56314 & Up & MELTF antisense RNA 1 \\
\hline C1QTNF2 & 1.695983 & $1.18 \mathrm{E}-66$ & $5.71 \mathrm{E}-64$ & 21.4328 & Up & $\mathrm{C} 1 \mathrm{q}$ and $\mathrm{TNF}$ related 2 \\
\hline CYS1 & 1.688006 & $6.01 \mathrm{E}-69$ & $3.57 \mathrm{E}-66$ & 21.9875 & Up & cystin 1 \\
\hline SLC6A4 & 1.687739 & $1.34 \mathrm{E}-23$ & $2.31 \mathrm{E}-22$ & 10.74587 & Up & solute carrier family 6 member 4 \\
\hline LINC00670 & 1.682454 & $2.21 \mathrm{E}-52$ & $3.9 \mathrm{E}-50$ & 18.00406 & Up & long intergenic non-protein coding RNA 670 \\
\hline COL14A1 & 1.681527 & 8.37E-50 & $1.15 \mathrm{E}-47$ & 17.38423 & Up & collagen type XIV alpha 1 chain \\
\hline AEBP1 & 1.678926 & 2.77E-45 & $2.51 \mathrm{E}-43$ & 16.29209 & $\mathrm{Up}$ & AE binding protein 1 \\
\hline TLL2 & 1.670045 & $4.29 \mathrm{E}-69$ & $2.7 \mathrm{E}-66$ & 22.023 & $\mathrm{Up}$ & tolloid like 2 \\
\hline LOC107986163 & 1.669682 & $3.03 \mathrm{E}-33$ & $1.1 \mathrm{E}-31$ & 13.30833 & Up & uncharacterized LOC107986163 \\
\hline NRK & 1.665994 & $9.57 \mathrm{E}-60$ & $2.88 \mathrm{E}-57$ & 19.7707 & Up & Nik related kinase \\
\hline EXOC3L4 & 1.657167 & $1.47 \mathrm{E}-23$ & $2.52 \mathrm{E}-22$ & 10.73476 & Up & exocyst complex component 3 like 4 \\
\hline HTR2A & 1.656339 & $9.15 \mathrm{E}-27$ & $2.03 \mathrm{E}-25$ & 11.61333 & Up & 5-hydroxytryptamine receptor $2 \mathrm{~A}$ \\
\hline HDC & 1.653783 & $5.15 \mathrm{E}-36$ & $2.25 \mathrm{E}-34$ & 14.00907 & Up & histidine decarboxylase \\
\hline GSTM5 & 1.650191 & $4.21 \mathrm{E}-45$ & 3.77E-43 & 16.24794 & Up & glutathione S-transferase mu 5 \\
\hline CD3D & 1.641321 & $1.18 \mathrm{E}-31$ & $3.86 \mathrm{E}-30$ & 12.90043 & Up & CD3d molecule \\
\hline ECRG4 & 1.632088 & $1.01 \mathrm{E}-46$ & $1.06 \mathrm{E}-44$ & 16.64023 & Up & ECRG4 augurin precursor \\
\hline FAP & 1.627064 & $6.1 \mathrm{E}-37$ & $2.9 \mathrm{E}-35$ & 14.24099 & Up & fibroblast activation protein alpha \\
\hline BPI & 1.624603 & $2.16 \mathrm{E}-31$ & $6.91 \mathrm{E}-30$ & 12.83272 & Up & bactericidal permeability increasing protein \\
\hline CYP11A1 & 1.621266 & 4.82E-52 & $8.15 \mathrm{E}-50$ & 17.92274 & Up & cytochrome P450 family 11 subfamily A member 1 \\
\hline LCN12 & 1.619771 & 4.59E-32 & $1.55 \mathrm{E}-30$ & 13.00586 & Up & lipocalin 12 \\
\hline MFAP4 & 1.616857 & $5.78 \mathrm{E}-73$ & $5.46 \mathrm{E}-70$ & 22.96383 & Up & microfibril associated protein 4 \\
\hline MYOC & 1.605119 & $1.96 \mathrm{E}-31$ & $6.3 \mathrm{E}-30$ & 12.84334 & Up & myocilin \\
\hline
\end{tabular}




\begin{tabular}{|c|c|c|c|c|c|c|}
\hline THY1 & 1.604584 & $1.17 \mathrm{E}-22$ & $1.87 \mathrm{E}-21$ & 10.48087 & Up & Thy- 1 cell surface antigen \\
\hline ITGAL & 1.604327 & 4.27E-46 & $4.14 \mathrm{E}-44$ & 16.48893 & Up & integrin subunit alpha $\mathrm{L}$ \\
\hline KIAA1755 & 1.603838 & 2.97E-55 & $6.63 \mathrm{E}-53$ & 18.69335 & Up & KIAA1755 \\
\hline FMOD & 1.601342 & $5.22 \mathrm{E}-42$ & $3.61 \mathrm{E}-40$ & 15.49365 & $\mathrm{Up}$ & fibromodulin \\
\hline GFRA3 & 1.59901 & $1.15 \mathrm{E}-35$ & $4.93 \mathrm{E}-34$ & 13.9215 & Up & GDNF family receptor alpha 3 \\
\hline PHLDA1 & 1.593007 & $1.25 \mathrm{E}-63$ & 4.89E-61 & 20.70408 & Up & pleckstrin homology like domain family A member 1 \\
\hline SH2D1B & 1.592988 & $1.23 \mathrm{E}-30$ & 3.7E-29 & 12.63695 & Up & SH2 domain containing $1 \mathrm{~B}$ \\
\hline IL34 & 1.590541 & 4.65E-46 & $4.48 \mathrm{E}-44$ & 16.4798 & Up & $\begin{array}{c}\text { interleukin } 34 \\
\text { ADAM metallopeptidase with thrombospondin type } 1\end{array}$ \\
\hline ADAMTS14 & 1.590348 & $1.8 \mathrm{E}-36$ & $8.26 \mathrm{E}-35$ & 14.12324 & Up & motif 14 \\
\hline APCDD1L-DT & 1.585375 & $8.02 \mathrm{E}-32$ & $2.64 \mathrm{E}-30$ & 12.94358 & Up & APCDD1L divergent transcript \\
\hline CMTM2 & 1.584966 & $3.97 \mathrm{E}-22$ & $5.98 \mathrm{E}-21$ & 10.33056 & Up & CKLF like MARVEL transmembrane domain containing 2 \\
\hline PROM1 & 1.584399 & $1.37 \mathrm{E}-53$ & $2.85 \mathrm{E}-51$ & 18.29382 & Up & prominin 1 \\
\hline TENM4 & 1.57826 & $2.99 \mathrm{E}-46$ & $2.97 \mathrm{E}-44$ & 16.52634 & Up & teneurintransmembrane protein 4 \\
\hline CD3E & 1.577059 & $1.44 \mathrm{E}-34$ & $5.75 \mathrm{E}-33$ & 13.64473 & Up & CD3e molecule \\
\hline TMEM30B & 1.573717 & $8.62 \mathrm{E}-43$ & $6.39 \mathrm{E}-41$ & 15.68505 & Up & transmembrane protein $30 \mathrm{~B}$ \\
\hline SARDH & 1.564223 & $1.52 \mathrm{E}-43$ & $1.2 \mathrm{E}-41$ & 15.86877 & $\mathrm{Up}$ & sarcosine dehydrogenase \\
\hline KLRB1 & 1.5636 & $2.78 \mathrm{E}-31$ & $8.82 \mathrm{E}-30$ & 12.80414 & Up & killer cell lectin like receptor B1 \\
\hline NAPSB & 1.559889 & $6.93 \mathrm{E}-30$ & $1.98 \mathrm{E}-28$ & 12.44091 & Up & $\begin{array}{l}\text { napsin B aspartic peptidase, pseudogene } \\
\text { solute carrier organic anion transporter family member }\end{array}$ \\
\hline SLCO4C1 & 1.559829 & $6.69 \mathrm{E}-31$ & $2.06 \mathrm{E}-29$ & 12.70541 & Up & $4 \mathrm{C} 1$ \\
\hline GABRD & 1.559743 & $8.36 \mathrm{E}-25$ & $1.58 \mathrm{E}-23$ & 11.07971 & Up & gamma-aminobutyric acid type A receptor delta subunit \\
\hline CD6 & 1.558091 & $6.44 \mathrm{E}-31$ & $1.99 \mathrm{E}-29$ & 12.70964 & $\mathrm{Up}$ & CD6 molecule \\
\hline LINC02028 & 1.556023 & $2.42 \mathrm{E}-42$ & $1.71 \mathrm{E}-40$ & 15.57541 & $\mathrm{Up}$ & long intergenic non-protein coding RNA 2028 \\
\hline RASL11B & 1.554174 & $6 \mathrm{E}-53$ & $1.14 \mathrm{E}-50$ & 18.14009 & $\mathrm{Up}$ & RAS like family 11 member B \\
\hline $\mathrm{TBX} 21$ & 1.552213 & $4.5 \mathrm{E}-31$ & 1.4E-29 & 12.74998 & Up & T-box transcription factor 21 \\
\hline IL2RB & 1.546229 & $1.51 \mathrm{E}-39$ & $8.57 \mathrm{E}-38$ & 14.88881 & Up & interleukin 2 receptor subunit beta \\
\hline HAAO & 1.54259 & $2.21 \mathrm{E}-46$ & $2.23 \mathrm{E}-44$ & 16.55819 & Up & 3-hydroxyanthranilate 3,4-dioxygenase \\
\hline MS4A1 & 1.541164 & $1.65 \mathrm{E}-21$ & $2.37 \mathrm{E}-20$ & 10.15294 & Up & membrane spanning 4-domains A1 \\
\hline LRRC17 & 1.539065 & $4.14 \mathrm{E}-53$ & 8.04E-51 & 18.17887 & Up & leucine rich repeat containing 17 \\
\hline CCL24 & 1.538643 & $5.69 \mathrm{E}-20$ & $7.15 \mathrm{E}-19$ & 9.70512 & Up & C-C motif chemokine ligand 24 \\
\hline LINC00906 & 1.535912 & $2.36 \mathrm{E}-23$ & $4 \mathrm{E}-22$ & 10.67709 & Up & long intergenic non-protein coding RNA 906 \\
\hline LMF1 & 1.535428 & $1.04 \mathrm{E}-41$ & $6.99 \mathrm{E}-40$ & 15.42078 & Up & lipase maturation factor 1 \\
\hline TNFRSF4 & 1.535 & $8.46 \mathrm{E}-14$ & $6.01 \mathrm{E}-13$ & 7.761017 & Up & TNF receptor superfamily member 4 \\
\hline $\mathrm{P} 3 \mathrm{H} 2$ & 1.532878 & $2.18 \mathrm{E}-36$ & $9.95 \mathrm{E}-35$ & 14.10244 & Up & prolyl 3-hydroxylase 2 \\
\hline LOC101926964 & 1.529325 & $1.15 \mathrm{E}-28$ & $2.98 \mathrm{E}-27$ & 12.12071 & Up & uncharacterized LOC101926964 \\
\hline PTN & 1.528239 & $1.59 \mathrm{E}-62$ & $5.8 \mathrm{E}-60$ & 20.43819 & $\mathrm{Up}$ & pleiotrophin \\
\hline EIF1AY & 1.527175 & 0.003828 & 0.007083 & 2.910526 & Up & eukaryotic translation initiation factor $1 \mathrm{~A}$ Y-linked \\
\hline DNAH8 & 1.526078 & $7.16 \mathrm{E}-28$ & $1.73 \mathrm{E}-26$ & 11.90949 & Up & dynein axonemal heavy chain 8 \\
\hline GREM1 & 1.524172 & $2 \mathrm{E}-13$ & $1.37 \mathrm{E}-12$ & 7.633388 & $\mathrm{Up}$ & gremlin 1, DAN family BMP antagonist \\
\hline CEACAM3 & 1.522791 & $2.87 \mathrm{E}-23$ & $4.85 \mathrm{E}-22$ & 10.65294 & Up & CEA cell adhesion molecule 3 \\
\hline ATRNL1 & 1.52238 & $1.39 \mathrm{E}-22$ & $2.19 \mathrm{E}-21$ & 10.45995 & $\mathrm{Up}$ & attractin like 1 \\
\hline FCN1 & 1.522239 & $4.41 \mathrm{E}-25$ & $8.52 \mathrm{E}-24$ & 11.15616 & $\mathrm{Up}$ & ficolin 1 \\
\hline AMHR2 & 1.519307 & $1.07 \mathrm{E}-26$ & $2.35 \mathrm{E}-25$ & 11.59475 & Up & anti-Mullerian hormone receptor type 2 \\
\hline
\end{tabular}




\begin{tabular}{|c|c|c|c|c|c|c|}
\hline CRHBP & 1.517324 & 7.94E-50 & $1.1 \mathrm{E}-47$ & 17.38973 & Up & corticotropin releasing hormone binding protein \\
\hline NME8 & 1.515954 & $5.23 \mathrm{E}-28$ & $1.29 \mathrm{E}-26$ & 11.94592 & Up & NME/NM23 family member 8 \\
\hline ZAP70 & 1.514658 & $7.62 \mathrm{E}-33$ & $2.68 \mathrm{E}-31$ & 13.2059 & Up & zeta chain of $\mathrm{T}$ cell receptor associated protein kinase 70 \\
\hline RPS4Y1 & 1.513872 & 0.003664 & 0.006805 & 2.924581 & Up & ribosomal protein S4 Y-linked 1 \\
\hline LIPH & 1.512512 & 7.39E-38 & $3.72 \mathrm{E}-36$ & 14.46955 & Up & lipase $\mathrm{H}$ \\
\hline FAM181B & 1.509658 & $1.41 \mathrm{E}-29$ & $3.94 \mathrm{E}-28$ & 12.36002 & Up & family with sequence similarity 181 member B \\
\hline LY9 & 1.506257 & $1.04 \mathrm{E}-25$ & $2.1 \mathrm{E}-24$ & 11.32764 & Up & lymphocyte antigen 9 \\
\hline CCR7 & 1.505912 & 4.46E-24 & $7.96 \mathrm{E}-23$ & 10.87865 & Up & C-C motif chemokine receptor 7 \\
\hline FBXL16 & 1.500323 & $7.88 \mathrm{E}-30$ & $2.24 \mathrm{E}-28$ & 12.42638 & Up & F-box and leucine rich repeat protein 16 \\
\hline IL17D & 1.492141 & $1.85 \mathrm{E}-48$ & $2.26 \mathrm{E}-46$ & 17.0602 & Up & interleukin $17 \mathrm{D}$ \\
\hline FBLN7 & 1.490721 & $2.97 \mathrm{E}-38$ & $1.54 \mathrm{E}-36$ & 14.56812 & Up & fibulin 7 \\
\hline CTD-3080P12.3 & 1.489908 & $3.27 \mathrm{E}-15$ & $2.65 \mathrm{E}-14$ & 8.231737 & Up & uncharacterized LOC101928857 \\
\hline $\mathrm{DIO} 2$ & 1.489605 & $1.7 \mathrm{E}-50$ & $2.45 \mathrm{E}-48$ & 17.55098 & Up & iodothyroninedeiodinase 2 \\
\hline ZBP1 & 1.487429 & $3.84 \mathrm{E}-33$ & $1.37 \mathrm{E}-31$ & 13.28194 & Up & Z-DNA binding protein 1 \\
\hline SFTA1P & 1.486617 & $1.26 \mathrm{E}-25$ & $2.52 \mathrm{E}-24$ & 11.30493 & Up & surfactant associated 1 , pseudogene \\
\hline $\mathrm{CD} 2$ & 1.485796 & $9.06 \mathrm{E}-31$ & $2.76 \mathrm{E}-29$ & 12.6712 & Up & $\mathrm{CD} 2$ molecule \\
\hline FCRL6 & 1.48399 & $2.5 \mathrm{E}-24$ & $4.54 \mathrm{E}-23$ & 10.94834 & Up & Fc receptor like 6 \\
\hline FZD10-AS1 & 1.483735 & $3.65 \mathrm{E}-33$ & $1.31 \mathrm{E}-31$ & 13.28767 & Up & FZD10 antisense divergent transcript \\
\hline CD1E & 1.483648 & $4.01 \mathrm{E}-21$ & $5.57 \mathrm{E}-20$ & 10.04196 & Up & CD1e molecule \\
\hline COL16A1 & 1.481494 & $1.07 \mathrm{E}-46$ & $1.11 \mathrm{E}-44$ & 16.63474 & Up & collagen type XVI alpha 1 chain \\
\hline EFCC1 & 1.476925 & $1.03 \mathrm{E}-45$ & $9.65 \mathrm{E}-44$ & 16.3961 & Up & EF-hand and coiled-coil domain containing 1 \\
\hline ETV4 & 1.475328 & $1.73 \mathrm{E}-37$ & $8.55 \mathrm{E}-36$ & 14.37775 & Up & ETS variant transcription factor 4 \\
\hline DLGAP1 & 1.473619 & $2.54 \mathrm{E}-25$ & 4.99E-24 & 11.22147 & Up & DLG associated protein 1 \\
\hline HYAL4 & 1.472457 & $1.68 \mathrm{E}-28$ & $4.29 \mathrm{E}-27$ & 12.07691 & $\mathrm{Up}$ & hyaluronidase 4 \\
\hline MCHR1 & 1.471883 & $1.03 \mathrm{E}-24$ & $1.94 \mathrm{E}-23$ & 11.05502 & Up & melanin concentrating hormone receptor 1 \\
\hline LOC101928731 & 1.467565 & $8.57 \mathrm{E}-36$ & $3.7 \mathrm{E}-34$ & 13.95348 & Up & uncharacterized LOC101928731 \\
\hline TIGIT & 1.467506 & $9.66 \mathrm{E}-26$ & $1.95 \mathrm{E}-24$ & 11.33618 & Up & T cell immunoreceptor with Ig and ITIM domains \\
\hline PRRT2 & 1.467191 & $4.38 \mathrm{E}-51$ & $6.84 \mathrm{E}-49$ & 17.69245 & Up & proline rich transmembrane protein 2 \\
\hline CA3 & 1.462163 & $2.97 \mathrm{E}-20$ & $3.81 \mathrm{E}-19$ & 9.788456 & Up & carbonic anhydrase 3 \\
\hline GADL1 & 1.461411 & $5.68 \mathrm{E}-20$ & 7.14E-19 & 9.705276 & $\mathrm{Up}$ & glutamate decarboxylase like 1 \\
\hline $\mathrm{CD} 3 \mathrm{G}$ & 1.458347 & $4.25 \mathrm{E}-26$ & $8.92 \mathrm{E}-25$ & 11.4331 & Up & CD3g molecule \\
\hline SPNS3 & 1.457263 & $4.56 \mathrm{E}-22$ & $6.83 \mathrm{E}-21$ & 10.31312 & Up & sphingolipid transporter 3 (putative) \\
\hline FERMT1 & 1.456951 & $1.48 \mathrm{E}-33$ & $5.45 \mathrm{E}-32$ & 13.38789 & Up & fermitin family member 1 \\
\hline GRIK4 & 1.454408 & $2.49 \mathrm{E}-31$ & 7.95E-30 & 12.81649 & $\mathrm{Up}$ & glutamate ionotropic receptor kainate type subunit 4 \\
\hline SDSL & 1.453371 & $8.03 \mathrm{E}-31$ & $2.46 \mathrm{E}-29$ & 12.68483 & Up & serine dehydratase like \\
\hline NRG1 & 1.452944 & $9.93 \mathrm{E}-21$ & $1.33 \mathrm{E}-19$ & 9.927464 & Up & neuregulin 1 \\
\hline TARP & 1.452369 & $1.3 \mathrm{E}-25$ & $2.6 \mathrm{E}-24$ & 11.30092 & Up & TCR gamma alternate reading frame protein \\
\hline SCG2 & 1.450549 & $1.85 \mathrm{E}-16$ & $1.69 \mathrm{E}-15$ & 8.633202 & Up & secretogranin II \\
\hline EGR2 & 1.448114 & $5.93 \mathrm{E}-26$ & $1.22 \mathrm{E}-24$ & 11.39379 & Up & early growth response 2 \\
\hline GSG1L & 1.445137 & $1.2 \mathrm{E}-11$ & $6.83 \mathrm{E}-11$ & 7.00315 & Up & GSG1 like \\
\hline SCARA3 & 1.444259 & $5.52 \mathrm{E}-63$ & $2.11 \mathrm{E}-60$ & 20.54857 & Up & scavenger receptor class A member 3 \\
\hline UBASH3A & 1.439792 & $5.08 \mathrm{E}-25$ & $9.75 \mathrm{E}-24$ & 11.1393 & Up & ubiquitin associated and $\mathrm{SH} 3$ domain containing A \\
\hline $\mathrm{DMC1}$ & 1.439293 & $5.98 \mathrm{E}-61$ & $2.04 \mathrm{E}-58$ & 20.05974 & Up & DNA meiotic recombinase 1 \\
\hline
\end{tabular}




\begin{tabular}{|c|c|c|c|c|c|c|}
\hline NGEF & 1.439001 & $1.44 \mathrm{E}-19$ & $1.75 \mathrm{E}-18$ & 9.585604 & Up & neuronal guanine nucleotide exchange factor \\
\hline DNAJC22 & 1.437657 & $3.51 \mathrm{E}-29$ & $9.52 \mathrm{E}-28$ & 12.25626 & Up & DnaJ heat shock protein family (Hsp40) member $\mathrm{C} 22$ \\
\hline SMPD3 & 1.436276 & 7.03E-22 & $1.04 \mathrm{E}-20$ & 10.25951 & Up & sphingomyelinphosphodiesterase 3 \\
\hline CCDC168 & 1.436207 & 4.17E-29 & $1.12 \mathrm{E}-27$ & 12.23649 & Up & coiled-coil domain containing 168 \\
\hline CRABP2 & 1.432348 & $7.38 \mathrm{E}-30$ & $2.1 \mathrm{E}-28$ & 12.43378 & Up & cellular retinoic acid binding protein 2 \\
\hline PRPH & 1.430396 & 4.69E-28 & $1.16 \mathrm{E}-26$ & 11.95832 & Up & peripherin \\
\hline PALM3 & 1.430275 & $4.36 \mathrm{E}-28$ & $1.08 \mathrm{E}-26$ & 11.9668 & Up & paralemmin 3 \\
\hline FOXS1 & 1.429428 & $2.74 \mathrm{E}-19$ & $3.24 \mathrm{E}-18$ & 9.502675 & Up & forkhead box S1 \\
\hline ITIH5 & 1.429207 & $3.76 \mathrm{E}-74$ & $4.34 \mathrm{E}-71$ & 23.25374 & Up & inter-alpha-trypsin inhibitor heavy chain 5 \\
\hline SKAP1 & 1.428481 & $2.6 \mathrm{E}-28$ & $6.61 \mathrm{E}-27$ & 12.02632 & Up & src kinase associated phosphoprotein 1 \\
\hline ITGBL1 & 1.42419 & $1.72 \mathrm{E}-33$ & $6.3 \mathrm{E}-32$ & 13.37084 & Up & integrin subunit beta like 1 \\
\hline COL8A2 & 1.424064 & $2.12 \mathrm{E}-45$ & $1.95 \mathrm{E}-43$ & 16.32026 & Up & collagen type VIII alpha 2 chain \\
\hline KIRREL3 & 1.420945 & $8.98 \mathrm{E}-32$ & $2.95 \mathrm{E}-30$ & 12.93087 & Up & kirre like nephrin family adhesion molecule 3 \\
\hline BEX1 & 1.420178 & $1.54 \mathrm{E}-22$ & $2.41 \mathrm{E}-21$ & 10.44694 & Up & brain expressed X-linked 1 \\
\hline FCER2 & 1.416596 & $3.81 \mathrm{E}-22$ & $5.76 \mathrm{E}-21$ & 10.33555 & Up & $\mathrm{Fc}$ fragment of $\mathrm{IgE}$ receptor II \\
\hline SLC24A2 & 1.415998 & $6.97 \mathrm{E}-21$ & $9.53 \mathrm{E}-20$ & 9.972135 & Up & solute carrier family 24 member 2 \\
\hline TBC1D10C & 1.415564 & $3.36 \mathrm{E}-24$ & $6.04 \mathrm{E}-23$ & 10.91276 & Up & $\mathrm{TBC} 1$ domain family member $10 \mathrm{C}$ \\
\hline ESR1 & 1.415141 & $6.38 \mathrm{E}-59$ & $1.77 \mathrm{E}-56$ & 19.57293 & Up & estrogen receptor 1 \\
\hline $\mathrm{SCN} 2 \mathrm{~B}$ & 1.414446 & $3.55 \mathrm{E}-55$ & $7.84 \mathrm{E}-53$ & 18.67482 & Up & sodium voltage-gated channel beta subunit 2 \\
\hline PADI4 & 1.413441 & $5.7 \mathrm{E}-17$ & $5.47 \mathrm{E}-16$ & 8.793997 & Up & peptidyl arginine deiminase 4 \\
\hline OMG & 1.411113 & $2.11 \mathrm{E}-29$ & $5.84 \mathrm{E}-28$ & 12.31411 & Up & oligodendrocyte myelin glycoprotein \\
\hline CTHRC1 & 1.410717 & $9.47 \mathrm{E}-28$ & $2.26 \mathrm{E}-26$ & 11.87721 & Up & collagen triple helix repeat containing 1 \\
\hline LEF1 & 1.409598 & $1.53 \mathrm{E}-33$ & $5.64 \mathrm{E}-32$ & 13.38369 & Up & lymphoid enhancer binding factor 1 \\
\hline SYTL1 & 1.405901 & $3.05 \mathrm{E}-23$ & $5.12 \mathrm{E}-22$ & 10.64567 & Up & synaptotagmin like 1 \\
\hline CCL22 & 1.404475 & $2.6 \mathrm{E}-17$ & $2.58 \mathrm{E}-16$ & 8.900267 & Up & C-C motif chemokine ligand 22 \\
\hline CLEC4F & 1.403759 & $3.69 \mathrm{E}-20$ & $4.71 \mathrm{E}-19$ & 9.760544 & Up & C-type lectin domain family 4 member $F$ \\
\hline P2RX6 & 1.403444 & $3.73 \mathrm{E}-27$ & $8.5 \mathrm{E}-26$ & 11.71788 & Up & purinergic receptor $\mathrm{P} 2 \mathrm{X} 6$ \\
\hline TGFB2 & 1.399181 & $2.8 \mathrm{E}-29$ & 7.65E-28 & 12.2821 & Up & transforming growth factor beta 2 \\
\hline LINC00484 & 1.397493 & $1.11 \mathrm{E}-28$ & $2.89 \mathrm{E}-27$ & 12.12447 & Up & long intergenic non-protein coding RNA 484 \\
\hline GALNT5 & 1.396805 & $7.38 \mathrm{E}-23$ & $1.2 \mathrm{E}-21$ & 10.53766 & Up & polypeptide $\mathrm{N}$-acetylgalactosaminyltransferase 5 \\
\hline LOC101929705 & 1.396659 & $2.98 \mathrm{E}-48$ & $3.62 \mathrm{E}-46$ & 17.01031 & Up & uncharacterized LOC101929705 \\
\hline DACT2 & 1.393311 & 2.7E-16 & $2.43 \mathrm{E}-15$ & 8.580885 & Up & dishevelled binding antagonist of beta catenin 2 \\
\hline WNT10B & 1.388628 & $1.31 \mathrm{E}-24$ & $2.44 \mathrm{E}-23$ & 11.02636 & Up & Wnt family member $10 \mathrm{~B}$ \\
\hline MATN2 & 1.387237 & $1.33 \mathrm{E}-71$ & $1.06 \mathrm{E}-68$ & 22.63224 & Up & matrilin 2 \\
\hline AZIN2 & 1.38529 & $1.78 \mathrm{E}-64$ & $7.56 \mathrm{E}-62$ & 20.90748 & Up & antizyme inhibitor 2 \\
\hline B3GALT5 & 1.381072 & $1.64 \mathrm{E}-19$ & $1.98 \mathrm{E}-18$ & 9.568734 & Up & beta-1,3-galactosyltransferase 5 \\
\hline LINC00968 & 1.380375 & $2.74 \mathrm{E}-31$ & $8.72 \mathrm{E}-30$ & 12.80576 & Up & long intergenic non-protein coding RNA 968 \\
\hline RIMS4 & 1.378732 & $2.96 \mathrm{E}-24$ & $5.34 \mathrm{E}-23$ & 10.92819 & Up & regulating synaptic membrane exocytosis 4 \\
\hline RASGRP1 & 1.37836 & $2.81 \mathrm{E}-28$ & $7.1 \mathrm{E}-27$ & 12.01751 & Up & RAS guanyl releasing protein 1 \\
\hline CPXM2 & 1.376429 & $6.43 \mathrm{E}-39$ & $3.5 \mathrm{E}-37$ & 14.73275 & Up & carboxypeptidase X, M14 family member 2 \\
\hline FMO1 & 1.375361 & $2.26 \mathrm{E}-21$ & $3.2 \mathrm{E}-20$ & 10.11404 & Up & flavin containing dimethylanilinemonoxygenase 1 \\
\hline CD83 & 1.374802 & $5.06 \mathrm{E}-51$ & 7.79E-49 & 17.67736 & Up & CD83 molecule \\
\hline SYT17 & 1.374273 & $3.68 \mathrm{E}-62$ & $1.32 \mathrm{E}-59$ & 20.3506 & Up & synaptotagmin 17 \\
\hline
\end{tabular}




\begin{tabular}{|c|c|c|c|c|c|c|}
\hline ABCG2 & 1.373113 & $9.52 \mathrm{E}-47$ & $1 \mathrm{E}-44$ & 16.64667 & Up & $\begin{array}{l}\text { ATP binding cassette subfamily G member } 2 \text { (Junior blood } \\
\text { group) }\end{array}$ \\
\hline FAM133A & 1.369938 & $1.35 \mathrm{E}-18$ & $1.5 \mathrm{E}-17$ & 9.294288 & $\mathrm{Up}$ & family with sequence similarity 133 member A \\
\hline FEZF1-AS1 & 1.36779 & $8.24 \mathrm{E}-23$ & $1.34 \mathrm{E}-21$ & 10.52416 & Up & FEZF1 antisense RNA 1 \\
\hline DNAAF3 & 1.367564 & $6.54 \mathrm{E}-30$ & $1.87 \mathrm{E}-28$ & 12.44747 & Up & $\begin{array}{c}\text { dynein axonemal assembly factor } 3 \\
\text { immunoglobulin like and fibronectin type III domain }\end{array}$ \\
\hline IGFN1 & 1.364677 & $5.51 \mathrm{E}-21$ & 7.61E-20 & 10.00175 & $\mathrm{Up}$ & containing 1 \\
\hline SH2D1A & 1.363761 & $7.86 \mathrm{E}-21$ & $1.07 \mathrm{E}-19$ & 9.957054 & Up & $\mathrm{SH} 2$ domain containing $1 \mathrm{~A}$ \\
\hline SRGAP3-AS4 & 1.363047 & $1.3 \mathrm{E}-18$ & $1.45 \mathrm{E}-17$ & 9.298963 & Up & SRGAP3 antisense RNA 4 \\
\hline COL9A2 & 1.362168 & 4.17E-34 & $1.61 \mathrm{E}-32$ & 13.52748 & Up & collagen type IX alpha 2 chain \\
\hline SIT1 & 1.359564 & $7.31 \mathrm{E}-23$ & $1.19 \mathrm{E}-21$ & 10.5389 & Up & signaling threshold regulating transmembrane adaptor 1 \\
\hline CHRDL1 & 1.359548 & $1.08 \mathrm{E}-18$ & $1.21 \mathrm{E}-17$ & 9.323916 & Up & chordin like 1 \\
\hline RGS17 & 1.359486 & $6.69 \mathrm{E}-25$ & $1.28 \mathrm{E}-23$ & 11.10644 & Up & regulator of $\mathrm{G}$ protein signaling 17 \\
\hline ACKR4 & 1.358827 & $1.17 \mathrm{E}-40$ & 7.32E-39 & 15.16203 & $\mathrm{Up}$ & atypical chemokine receptor 4 \\
\hline COL1A1 & 1.358302 & $1.03 \mathrm{E}-23$ & $1.79 \mathrm{E}-22$ & 10.77798 & Up & collagen type I alpha 1 chain \\
\hline CD5 & 1.356328 & $1.97 \mathrm{E}-22$ & $3.06 \mathrm{E}-21$ & 10.41671 & $\mathrm{Up}$ & CD5 molecule \\
\hline SOX8 & 1.353422 & $1.7 \mathrm{E}-41$ & $1.13 \mathrm{E}-39$ & 15.36824 & Up & SRY-box transcription factor 8 \\
\hline LRRC77P & 1.351962 & $3.85 \mathrm{E}-39$ & $2.11 \mathrm{E}-37$ & 14.78807 & $\mathrm{Up}$ & leucine rich repeat containing 77 , pseudogene \\
\hline UNC5B-AS1 & 1.351117 & $1.06 \mathrm{E}-12$ & $6.71 \mathrm{E}-12$ & 7.381669 & Up & UNC5B antisense RNA 1 \\
\hline SCG5 & 1.350517 & $2.08 \mathrm{E}-24$ & $3.81 \mathrm{E}-23$ & 10.97082 & Up & secretogranin $\mathrm{V}$ \\
\hline LINC01267 & 1.348563 & $1.11 \mathrm{E}-18$ & $1.25 \mathrm{E}-17$ & 9.319702 & Up & long intergenic non-protein coding RNA 1267 \\
\hline RXRG & 1.346393 & 4.44E-37 & $2.14 \mathrm{E}-35$ & 14.2756 & Up & retinoid $\mathrm{X}$ receptor gamma \\
\hline $\mathrm{CD} 27$ & 1.345829 & $1.13 \mathrm{E}-16$ & $1.06 \mathrm{E}-15$ & 8.700302 & Up & CD27 molecule \\
\hline GLYATL2 & 1.342594 & $9.82 \mathrm{E}-35$ & 3.98E-33 & 13.68647 & $\mathrm{Up}$ & glycine-N-acyltransferase like 2 \\
\hline ANKRD24 & 1.342518 & $1.54 \mathrm{E}-25$ & 3.07E-24 & 11.28066 & Up & ankyrin repeat domain 24 \\
\hline INKA1 & 1.340521 & $8.59 \mathrm{E}-22$ & $1.26 \mathrm{E}-20$ & 10.23452 & Up & inka box actin regulator 1 \\
\hline IFI44L & 1.338481 & $1 \mathrm{E}-44$ & 8.57E-43 & 16.15631 & $\mathrm{Up}$ & interferon induced protein 44 like \\
\hline MS4A2 & 1.33714 & $2.29 \mathrm{E}-16$ & $2.08 \mathrm{E}-15$ & 8.603622 & Up & membrane spanning 4-domains A2 \\
\hline RHCG & 1.336804 & $4.25 \mathrm{E}-12$ & $2.55 \mathrm{E}-11$ & 7.166944 & Up & $\mathrm{Rh}$ family $\mathrm{C}$ glycoprotein \\
\hline METTL21EP & 1.332538 & $1.34 \mathrm{E}-27$ & $3.17 \mathrm{E}-26$ & 11.83678 & $\mathrm{Up}$ & methyltransferase like 21E, pseudogene \\
\hline CEMIP & 1.332429 & $4.08 \mathrm{E}-15$ & $3.29 \mathrm{E}-14$ & 8.200242 & Up & cell migration inducing hyaluronidase 1 \\
\hline $\mathrm{CD} 247$ & 1.330672 & 4.07E-38 & $2.09 \mathrm{E}-36$ & 14.53411 & Up & CD247 molecule \\
\hline F2RL2 & 1.33014 & $1.01 \mathrm{E}-24$ & $1.91 \mathrm{E}-23$ & 11.05693 & Up & coagulation factor II thrombin receptor like 2 \\
\hline IL31RA & 1.327493 & 7.49E-14 & $5.34 \mathrm{E}-13$ & 7.779083 & Up & interleukin 31 receptor $\mathrm{A}$ \\
\hline USP9Y & 1.322424 & 0.009551 & 0.016327 & 2.605368 & Up & ubiquitin specific peptidase 9 Y-linked \\
\hline BRINP1 & 1.317235 & $1.88 \mathrm{E}-21$ & $2.68 \mathrm{E}-20$ & 10.13695 & $\mathrm{Up}$ & BMP/retinoic acid inducible neural specific 1 \\
\hline MOXD1 & 1.313654 & 3.61E-40 & $2.16 \mathrm{E}-38$ & 15.04169 & Up & monooxygenase DBH like 1 \\
\hline MED12L & 1.312022 & $6.18 \mathrm{E}-28$ & $1.5 \mathrm{E}-26$ & 11.92652 & Up & mediator complex subunit $12 \mathrm{~L}$ \\
\hline LOC101927811 & 1.310553 & $1.22 \mathrm{E}-27$ & $2.89 \mathrm{E}-26$ & 11.84779 & Up & uncharacterized LOC101927811 \\
\hline DNAJC27-AS1 & 1.309638 & $3.13 \mathrm{E}-32$ & $1.06 \mathrm{E}-30$ & 13.04877 & $\mathrm{Up}$ & DNAJC27 antisense RNA 1 \\
\hline FAM225B & 1.309169 & $1.21 \mathrm{E}-25$ & $2.43 \mathrm{E}-24$ & 11.30969 & Up & family with sequence similarity 225 member B \\
\hline SERPINE2 & 1.30842 & $1.21 \mathrm{E}-34$ & $4.89 \mathrm{E}-33$ & 13.66314 & Up & serpin family E member 2 \\
\hline C1QTNF9 & 1.308078 & $6.34 \mathrm{E}-32$ & $2.1 \mathrm{E}-30$ & 12.96982 & Up & $\mathrm{C} 1 \mathrm{q}$ and $\mathrm{TNF}$ related 9 \\
\hline LMX1A & 1.305166 & $2.75 \mathrm{E}-22$ & 4.22E-21 & 10.37562 & Up & LIM homeobox transcription factor 1 alpha \\
\hline
\end{tabular}




\begin{tabular}{|c|c|c|c|c|c|c|}
\hline MIR181A2HG & 1.303865 & $6.57 \mathrm{E}-32$ & $2.17 \mathrm{E}-30$ & 12.96582 & Up & MIR181A2 host gene \\
\hline THBS4 & 1.302766 & $3.46 \mathrm{E}-33$ & $1.24 \mathrm{E}-31$ & 13.2937 & Up & thrombospondin 4 \\
\hline $\mathrm{ROBO} 2$ & 1.302226 & 4.74E-19 & $5.49 \mathrm{E}-18$ & 9.431255 & Up & roundabout guidance receptor 2 \\
\hline LOC105373878 & 1.300436 & $9.52 \mathrm{E}-38$ & 4.77E-36 & 14.4422 & Up & uncharacterized LOC105373878 \\
\hline ATP1B2 & 1.30027 & $1.37 \mathrm{E}-57$ & $3.57 \mathrm{E}-55$ & 19.25327 & Up & ATPase $\mathrm{Na}+/ \mathrm{K}+$ transporting subunit beta 2 \\
\hline FHAD1 & 1.29999 & 3.37E-26 & $7.14 \mathrm{E}-25$ & 11.46057 & Up & forkhead associated phosphopeptide binding domain 1 \\
\hline LCK & 1.297893 & $2.03 \mathrm{E}-30$ & $5.98 \mathrm{E}-29$ & 12.57993 & Up & LCK proto-oncogene, Src family tyrosine kinase \\
\hline TMEM156 & 1.294685 & $1.97 \mathrm{E}-22$ & $3.06 \mathrm{E}-21$ & 10.41685 & Up & transmembrane protein 156 \\
\hline LINC00211 & 1.293649 & $1.35 \mathrm{E}-30$ & 4.05E-29 & 12.62631 & Up & $\begin{array}{l}\text { long intergenic non-protein coding RNA } 211 \\
\text { pleckstrin homology, MyTH4 and FERM domain }\end{array}$ \\
\hline PLEKHH 2 & 1.29203 & $2.39 \mathrm{E}-30$ & $7 \mathrm{E}-29$ & 12.56159 & Up & containing $\mathrm{H} 2$ \\
\hline LINC01426 & 1.289853 & $9.64 \mathrm{E}-23$ & $1.55 \mathrm{E}-21$ & 10.50485 & Up & long intergenic non-protein coding RNA 1426 \\
\hline ZMYND15 & 1.289009 & $7.84 \mathrm{E}-39$ & $4.22 \mathrm{E}-37$ & 14.71153 & Up & zinc finger MYND-type containing 15 \\
\hline UCHL1 & 1.288567 & $6 \mathrm{E}-25$ & $1.15 \mathrm{E}-23$ & 11.11939 & Up & ubiquitin C-terminal hydrolase L1 \\
\hline MYOZ1 & 1.288488 & $2.05 \mathrm{E}-25$ & 4.04E-24 & 11.24716 & Up & myozenin 1 \\
\hline MAP3K7CL & 1.288168 & $8.27 \mathrm{E}-21$ & $1.12 \mathrm{E}-19$ & 9.950544 & Up & MAP3K7 C-terminal like \\
\hline PLCH2 & 1.287447 & $1.12 \mathrm{E}-18$ & $1.26 \mathrm{E}-17$ & 9.318392 & Up & phospholipase $\mathrm{C}$ eta 2 \\
\hline MRC2 & 1.286807 & $6.94 \mathrm{E}-34$ & $2.63 \mathrm{E}-32$ & 13.47131 & Up & mannose receptor $\mathrm{C}$ type 2 \\
\hline ADAMTSL1 & 1.286675 & $1.51 \mathrm{E}-31$ & $4.89 \mathrm{E}-30$ & 12.87241 & Up & ADAMTS like 1 \\
\hline PDE4C & 1.285231 & $2.27 \mathrm{E}-38$ & $1.19 \mathrm{E}-36$ & 14.59704 & Up & phosphodiesterase $4 \mathrm{C}$ \\
\hline CXCL14 & 1.281807 & $6.76 \mathrm{E}-16$ & $5.83 \mathrm{E}-15$ & 8.453562 & Up & C-X-C motif chemokine ligand 14 \\
\hline GDNF & 1.280842 & $2.33 \mathrm{E}-24$ & 4.25E-23 & 10.95683 & Up & glial cell derived neurotrophic factor \\
\hline ASB18 & 1.280174 & $5.71 \mathrm{E}-37$ & $2.73 \mathrm{E}-35$ & 14.24819 & Up & ankyrin repeat and SOCS box containing 18 \\
\hline HHIP & 1.278593 & 7.98E-19 & $9.06 \mathrm{E}-18$ & 9.363129 & Up & hedgehog interacting protein \\
\hline KDM5D & 1.277307 & 0.011648 & 0.019535 & 2.535361 & Up & lysine demethylase $5 \mathrm{D}$ \\
\hline MIR3142HG & 1.277276 & $1.35 \mathrm{E}-26$ & $2.93 \mathrm{E}-25$ & 11.5679 & Up & MIR3142 host gene \\
\hline LTBP2 & 1.274413 & $1.1 \mathrm{E}-34$ & $4.45 \mathrm{E}-33$ & 13.67374 & Up & latent transforming growth factor beta binding protein 2 \\
\hline IRX6 & 1.271621 & $1.65 \mathrm{E}-28$ & $4.22 \mathrm{E}-27$ & 12.079 & Up & iroquoishomeobox 6 \\
\hline CLEC11A & 1.271266 & $1.43 \mathrm{E}-22$ & $2.25 \mathrm{E}-21$ & 10.45611 & Up & C-type lectin domain containing $11 \mathrm{~A}$ \\
\hline IDO1 & 1.270315 & $2.09 \mathrm{E}-16$ & $1.91 \mathrm{E}-15$ & 8.615828 & Up & indoleamine 2,3-dioxygenase 1 \\
\hline C1QTNF9B & 1.268225 & $7.19 \mathrm{E}-17$ & $6.84 \mathrm{E}-16$ & 8.76235 & Up & $\mathrm{C} 1 \mathrm{q}$ and $\mathrm{TNF}$ related $9 \mathrm{~B}$ \\
\hline CRYM & 1.266414 & $1.15 \mathrm{E}-47$ & $1.3 \mathrm{E}-45$ & 16.86886 & Up & crystallin mu \\
\hline EFCAB1 & 1.265871 & $4.84 \mathrm{E}-24$ & $8.61 \mathrm{E}-23$ & 10.86895 & Up & EF-hand calcium binding domain 1 \\
\hline DDX3Y & 1.264424 & 0.013065 & 0.021716 & 2.494173 & Up & DEAD-box helicase 3 Y-linked \\
\hline CHIT1 & 1.264407 & 4.27E-10 & 2.05E-09 & 6.417928 & Up & chitinase 1 \\
\hline GNG8 & 1.2627 & $8.4 \mathrm{E}-11$ & 4.37E-10 & 6.689199 & Up & G protein subunit gamma 8 \\
\hline NT5E & 1.261748 & $1.1 \mathrm{E}-52$ & $2.02 \mathrm{E}-50$ & 18.07717 & Up & 5'-nucleotidase ecto \\
\hline HCG20 & 1.261078 & $2.49 \mathrm{E}-24$ & $4.52 \mathrm{E}-23$ & 10.94906 & Up & HLA complex group 20 \\
\hline NEURL1 & 1.260771 & $1.31 \mathrm{E}-24$ & $2.45 \mathrm{E}-23$ & 11.0258 & Up & neuralized E3 ubiquitin protein ligase 1 \\
\hline EYS & 1.260064 & $7.24 \mathrm{E}-19$ & $8.26 \mathrm{E}-18$ & 9.375881 & Up & eyes shut homolog \\
\hline GLI2 & 1.255414 & $6.95 \mathrm{E}-43$ & $5.21 \mathrm{E}-41$ & 15.70783 & Up & GLI family zinc finger 2 \\
\hline LINC01133 & 1.254973 & $2.04 \mathrm{E}-14$ & $1.54 \mathrm{E}-13$ & 7.969277 & Up & long intergenic non-protein coding RNA 1133 \\
\hline LOC105371795 & 1.253649 & $3.74 \mathrm{E}-17$ & $3.66 \mathrm{E}-16$ & 8.851004 & Up & uncharacterized LOC105371795 \\
\hline
\end{tabular}




\begin{tabular}{|c|c|c|c|c|c|c|}
\hline DPT & 1.250345 & $5.78 \mathrm{E}-42$ & $3.96 \mathrm{E}-40$ & 15.48293 & $\mathrm{Up}$ & dermatopontin \\
\hline PRR15 & 1.249204 & $2.22 \mathrm{E}-21$ & $3.15 \mathrm{E}-20$ & 10.11632 & Up & proline rich 15 \\
\hline CTNNA2 & 1.248053 & $6.25 \mathrm{E}-22$ & $9.25 \mathrm{E}-21$ & 10.2742 & $\mathrm{Up}$ & catenin alpha 2 \\
\hline HMCN2 & 1.24733 & $1.65 \mathrm{E}-24$ & $3.05 \mathrm{E}-23$ & 10.99834 & $\mathrm{Up}$ & hemicentin 2 \\
\hline ITGB2-AS1 & 1.247241 & $6.45 \mathrm{E}-29$ & $1.72 \mathrm{E}-27$ & 12.18654 & $\mathrm{Up}$ & ITGB2 antisense RNA 1 \\
\hline TLR7 & 1.246342 & 4.37E-26 & $9.15 \mathrm{E}-25$ & 11.42984 & $\mathrm{Up}$ & toll like receptor 7 \\
\hline HLA-DQA1 & 1.244186 & 3.69E-21 & $5.15 \mathrm{E}-20$ & 10.05236 & Up & major histocompatibility complex, class II, DQ alpha 1 \\
\hline TAC4 & 1.24286 & $1.46 \mathrm{E}-20$ & $1.91 \mathrm{E}-19$ & 9.878964 & $\mathrm{Up}$ & tachykinin precursor 4 \\
\hline LRRC52-AS1 & 1.241509 & $7.78 \mathrm{E}-13$ & $5.01 \mathrm{E}-12$ & 7.428482 & Up & LRRC52 antisense RNA 1 \\
\hline PPM1K-DT & 1.240771 & $1.97 \mathrm{E}-10$ & $9.85 \mathrm{E}-10$ & 6.547691 & $\mathrm{Up}$ & PPM1K divergent transcript \\
\hline PIEZO2 & 1.240568 & $7.72 \mathrm{E}-16$ & $6.63 \mathrm{E}-15$ & 8.434952 & Up & piezo type mechanosensitive ion channel component 2 \\
\hline $\mathrm{CCDC} 80$ & 1.239608 & $1.42 \mathrm{E}-30$ & 4.24E-29 & 12.62065 & Up & coiled-coil domain containing 80 \\
\hline DUSP15 & 1.239063 & $4.11 \mathrm{E}-35$ & $1.7 \mathrm{E}-33$ & 13.78207 & Up & dual specificity phosphatase 15 \\
\hline GNLY & 1.238419 & $1.78 \mathrm{E}-27$ & 4.16E-26 & 11.80405 & Up & granulysin \\
\hline CNTNAP2 & 1.235959 & $5.04 \mathrm{E}-18$ & $5.34 \mathrm{E}-17$ & 9.11997 & Up & contactin associated protein like 2 \\
\hline PRRX2 & 1.235523 & $3.93 \mathrm{E}-12$ & $2.36 \mathrm{E}-11$ & 7.178965 & Up & paired related homeobox 2 \\
\hline DUOX2 & 1.23448 & $5.79 \mathrm{E}-28$ & $1.41 \mathrm{E}-26$ & 11.93408 & Up & dual oxidase 2 \\
\hline GNA14 & 1.233753 & $1.61 \mathrm{E}-50$ & $2.34 \mathrm{E}-48$ & 17.55626 & Up & G protein subunit alpha 14 \\
\hline PMP2 & 1.233661 & $5.07 \mathrm{E}-20$ & $6.39 \mathrm{E}-19$ & 9.719945 & Up & peripheral myelin protein 2 \\
\hline FOXO6-AS1 & 1.231713 & $1.06 \mathrm{E}-20$ & $1.42 \mathrm{E}-19$ & 9.918623 & $\mathrm{Up}$ & FOXO6 antisense RNA 1 \\
\hline MALRD1 & 1.231194 & $3.34 \mathrm{E}-18$ & $3.59 \mathrm{E}-17$ & 9.174723 & Up & MAM and LDL receptor class A domain containing 1 \\
\hline PHF21B & 1.227657 & $1.22 \mathrm{E}-30$ & $3.69 \mathrm{E}-29$ & 12.63719 & Up & PHD finger protein 21B \\
\hline OLFML1 & 1.224413 & $5.26 \mathrm{E}-65$ & $2.38 \mathrm{E}-62$ & 21.03513 & Up & olfactomedin like 1 \\
\hline TRIM17 & 1.221292 & $5.11 \mathrm{E}-26$ & $1.06 \mathrm{E}-24$ & 11.41147 & Up & tripartite motif containing 17 \\
\hline TSPAN10 & 1.220763 & $5.54 \mathrm{E}-31$ & $1.72 \mathrm{E}-29$ & 12.72652 & Up & tetraspanin 10 \\
\hline IER3 & 1.220245 & $1.19 \mathrm{E}-22$ & $1.9 \mathrm{E}-21$ & 10.4788 & Up & immediate early response 3 \\
\hline NUP62CL & 1.219897 & $2.88 \mathrm{E}-34$ & $1.12 \mathrm{E}-32$ & 13.56819 & Up & nucleoporin 62 C-terminal like \\
\hline GPA33 & 1.219144 & $1.29 \mathrm{E}-23$ & $2.22 \mathrm{E}-22$ & 10.75057 & Up & glycoprotein A33 \\
\hline CLEC9A & 1.21506 & $1.84 \mathrm{E}-16$ & $1.69 \mathrm{E}-15$ & 8.633518 & Up & C-type lectin domain containing 9A \\
\hline HMGA2-AS1 & 1.214586 & $5.25 \mathrm{E}-21$ & 7.26E-20 & 10.00787 & Up & $\begin{array}{c}\text { HMGA2 antisense RNA 1 } \\
\text { lncRNAupregulator of antiviral response interferon }\end{array}$ \\
\hline LUARIS & 1.213922 & $1.79 \mathrm{E}-17$ & $1.81 \mathrm{E}-16$ & 8.950795 & Up & $\begin{array}{c}\text { signaling } \\
\text { potassium calcium-activated channel subfamily } \mathrm{N} \text { member }\end{array}$ \\
\hline KCNN3 & 1.211097 & $5.05 \mathrm{E}-50$ & 7.1E-48 & 17.43693 & Up & 3 \\
\hline MSS51 & 1.211068 & $4.05 \mathrm{E}-43$ & $3.1 \mathrm{E}-41$ & 15.76499 & Up & MSS51 mitochondrial translational activator \\
\hline LOC286178 & 1.203156 & 3.35E-17 & $3.28 \mathrm{E}-16$ & 8.866208 & Up & uncharacterized LOC286178 \\
\hline BCL11B & 1.200808 & $5 \mathrm{E}-21$ & $6.92 \mathrm{E}-20$ & 10.01416 & Up & BAF chromatin remodeling complex subunit BCL11B \\
\hline FSCN1 & 1.200742 & $5.5 \mathrm{E}-22$ & $8.18 \mathrm{E}-21$ & 10.29007 & Up & fascin actin-bundling protein 1 \\
\hline ARSI & 1.199759 & $1.81 \mathrm{E}-14$ & $1.37 \mathrm{E}-13$ & 7.986748 & Up & arylsulfatase family member I \\
\hline TP63 & 1.199611 & $1.25 \mathrm{E}-32$ & $4.34 \mathrm{E}-31$ & 13.15108 & Up & tumor protein $\mathrm{p} 63$ \\
\hline APOA1-AS & 1.198437 & $1.23 \mathrm{E}-11$ & $6.96 \mathrm{E}-11$ & 6.999998 & Up & APOA1 antisense RNA \\
\hline LINC01531 & 1.197352 & $5.61 \mathrm{E}-13$ & $3.67 \mathrm{E}-12$ & 7.478264 & $\mathrm{Up}$ & long intergenic non-protein coding RNA 1531 \\
\hline CD40LG & 1.196777 & $8.21 \mathrm{E}-16$ & $7.01 \mathrm{E}-15$ & 8.42641 & $\mathrm{Up}$ & CD40 ligand \\
\hline CAMK4 & 1.196139 & $1.86 \mathrm{E}-19$ & $2.23 \mathrm{E}-18$ & 9.552711 & $\mathrm{Up}$ & calcium/calmodulin dependent protein kinase IV \\
\hline
\end{tabular}




\begin{tabular}{|c|c|c|c|c|c|c|}
\hline TM6SF2 & 1.194983 & $2.63 \mathrm{E}-30$ & $7.66 \mathrm{E}-29$ & 12.55083 & Up & transmembrane 6 superfamily member 2 \\
\hline TRAF3IP3 & 1.193405 & 4.01E-36 & $1.79 \mathrm{E}-34$ & 14.03636 & Up & TRAF3 interacting protein 3 \\
\hline SIGLEC8 & 1.192 & $1.1 \mathrm{E}-18$ & $1.23 \mathrm{E}-17$ & 9.321523 & Up & sialic acid binding Ig like lectin 8 \\
\hline WDR66 & 1.191782 & $5.11 \mathrm{E}-49$ & $6.63 \mathrm{E}-47$ & 17.19495 & Up & WD repeat domain 66 \\
\hline ALOX15 & 1.189497 & $2.11 \mathrm{E}-14$ & $1.59 \mathrm{E}-13$ & 7.96447 & Up & arachidonate 15-lipoxygenase \\
\hline KLHL35 & 1.186728 & 4.84E-19 & $5.59 \mathrm{E}-18$ & 9.428585 & Up & kelch like family member 35 \\
\hline ITGB7 & 1.184564 & $1.14 \mathrm{E}-39$ & $6.55 \mathrm{E}-38$ & 14.91886 & Up & integrin subunit beta 7 \\
\hline SEC14L6 & 1.18353 & $2.24 \mathrm{E}-18$ & $2.45 \mathrm{E}-17$ & 9.227693 & Up & SEC14 like lipid binding 6 \\
\hline PDIA2 & 1.181381 & $8.1 \mathrm{E}-21$ & $1.1 \mathrm{E}-19$ & 9.953216 & Up & protein disulfideisomerase family A member 2 \\
\hline LGI1 & 1.180437 & $1.29 \mathrm{E}-19$ & $1.57 \mathrm{E}-18$ & 9.600238 & Up & $\begin{array}{l}\text { leucine rich glioma inactivated } 1 \\
\text { pancreatic progenitor cell differentiation and proliferation }\end{array}$ \\
\hline PPDPF & 1.180084 & $2.23 \mathrm{E}-16$ & $2.03 \mathrm{E}-15$ & 8.60702 & Up & factor \\
\hline SYTL2 & 1.179465 & $1.01 \mathrm{E}-34$ & $4.07 \mathrm{E}-33$ & 13.68374 & Up & synaptotagmin like 2 \\
\hline ADAMTSL2 & 1.179365 & $2.6 \mathrm{E}-22$ & $4 \mathrm{E}-21$ & 10.38261 & Up & ADAMTS like 2 \\
\hline FZD2 & 1.178996 & $1.82 \mathrm{E}-18$ & $2 \mathrm{E}-17$ & 9.255263 & Up & frizzled class receptor 2 \\
\hline LAMB4 & 1.17768 & $7.69 \mathrm{E}-18$ & $8.02 \mathrm{E}-17$ & 9.063817 & Up & laminin subunit beta 4 \\
\hline NRIP2 & 1.176935 & $9.58 \mathrm{E}-49$ & $1.2 \mathrm{E}-46$ & 17.12912 & $\mathrm{Up}$ & nuclear receptor interacting protein 2 \\
\hline SULF1 & 1.175739 & $2.88 \mathrm{E}-38$ & $1.49 \mathrm{E}-36$ & 14.57145 & Up & sulfatase 1 \\
\hline ETV7 & 1.175707 & $8.16 \mathrm{E}-17$ & $7.74 \mathrm{E}-16$ & 8.745045 & Up & ETS variant transcription factor 7 \\
\hline ANKRD36BP2 & 1.171138 & $3.75 \mathrm{E}-18$ & $4.02 \mathrm{E}-17$ & 9.159248 & $\mathrm{Up}$ & $\begin{array}{l}\text { ankyrin repeat domain } 36 \mathrm{~B} \text { pseudogene } 2 \\
\text { collagen like tail subunit of asymmetric }\end{array}$ \\
\hline COLQ & 1.170037 & $5.17 \mathrm{E}-28$ & $1.27 \mathrm{E}-26$ & 11.94726 & Up & acetylcholinesterase \\
\hline PODXL2 & 1.169919 & $8.66 \mathrm{E}-47$ & $9.23 \mathrm{E}-45$ & 16.65665 & $\mathrm{Up}$ & podocalyxin like 2 \\
\hline LINC00501 & 1.169906 & $9.77 \mathrm{E}-31$ & $2.97 \mathrm{E}-29$ & 12.6627 & Up & long intergenic non-protein coding RNA 501 \\
\hline CARD11 & 1.169111 & $1.27 \mathrm{E}-22$ & $2.01 \mathrm{E}-21$ & 10.47111 & Up & caspase recruitment domain family member 11 \\
\hline ANO9 & 1.168436 & $6.51 \mathrm{E}-16$ & $5.62 \mathrm{E}-15$ & 8.458675 & Up & anoctamin 9 \\
\hline SERTAD4 & 1.167618 & $5.18 \mathrm{E}-28$ & $1.28 \mathrm{E}-26$ & 11.94687 & $\mathrm{Up}$ & SERTA domain containing 4 \\
\hline PYHIN1 & 1.16663 & $1.63 \mathrm{E}-21$ & $2.34 \mathrm{E}-20$ & 10.15473 & Up & pyrin and HIN domain family member 1 \\
\hline CD48 & 1.165664 & $5.88 \mathrm{E}-26$ & $1.21 \mathrm{E}-24$ & 11.39481 & Up & CD48 molecule \\
\hline C12orf75 & 1.164765 & $1.52 \mathrm{E}-28$ & $3.92 \mathrm{E}-27$ & 12.08817 & Up & chromosome 12 open reading frame 75 \\
\hline HTR2B & 1.161887 & $2.28 \mathrm{E}-18$ & $2.49 \mathrm{E}-17$ & 9.225086 & Up & 5-hydroxytryptamine receptor 2B \\
\hline ECM2 & 1.161863 & $9.81 \mathrm{E}-31$ & $2.97 \mathrm{E}-29$ & 12.66225 & Up & extracellular matrix protein 2 \\
\hline PDE5A & 1.160025 & $1.39 \mathrm{E}-39$ & 7.94E-38 & 14.89735 & Up & phosphodiesterase $5 \mathrm{~A}$ \\
\hline GZMK & 1.159035 & $4.82 \mathrm{E}-19$ & $5.58 \mathrm{E}-18$ & 9.429051 & Up & granzyme K \\
\hline TEX41 & 1.15826 & $7.5 \mathrm{E}-23$ & $1.22 \mathrm{E}-21$ & 10.53572 & Up & testis expressed 41 \\
\hline IL1RL1 & -4.16665 & $1.16 \mathrm{E}-92$ & $8.03 \mathrm{E}-89$ & -27.8886 & Down & interleukin 1 receptor like 1 \\
\hline RNASE2 & -3.13727 & $1.02 \mathrm{E}-71$ & $8.46 \mathrm{E}-69$ & -22.6604 & Down & ribonuclease A family member 2 \\
\hline ALOX15B & -3.04933 & $8.54 \mathrm{E}-42$ & $5.82 \mathrm{E}-40$ & -15.4414 & Down & arachidonate 15 -lipoxygenase type $\mathrm{B}$ \\
\hline LCN10 & -3.01762 & $7.59 \mathrm{E}-61$ & $2.5 \mathrm{E}-58$ & -20.0349 & Down & lipocalin 10 \\
\hline TUBA3E & -2.99401 & $5.3 \mathrm{E}-73$ & $5.25 \mathrm{E}-70$ & -22.973 & Down & tubulin alpha $3 \mathrm{e}$ \\
\hline TUBA3D & -2.93212 & $1.14 \mathrm{E}-70$ & $8.14 \mathrm{E}-68$ & -22.4056 & Down & tubulin alpha $3 \mathrm{~d}$ \\
\hline MYH6 & -2.7545 & $1.4 \mathrm{E}-76$ & $2.23 \mathrm{E}-73$ & -23.8495 & Down & myosin heavy chain 6 \\
\hline PI15 & -2.74552 & 3.93E-40 & $2.34 \mathrm{E}-38$ & -15.0328 & Down & peptidase inhibitor 15 \\
\hline TUBA3C & -2.74348 & $1.64 \mathrm{E}-56$ & $4 \mathrm{E}-54$ & -18.9952 & Down & tubulin alpha $3 c$ \\
\hline
\end{tabular}




\begin{tabular}{|c|c|c|c|c|c|c|}
\hline CYP4B 1 & -2.71576 & $9.65 \mathrm{E}-56$ & $2.23 \mathrm{E}-53$ & -18.8104 & Down & cytochrome P450 family 4 subfamily B member 1 \\
\hline NPTX2 & -2.59581 & $1.15 \mathrm{E}-68$ & $6.46 \mathrm{E}-66$ & -21.9193 & Down & neuronal pentraxin 2 \\
\hline AOX1 & -2.57613 & $8.34 \mathrm{E}-69$ & 4.81E-66 & -21.953 & Down & aldehyde oxidase 1 \\
\hline PLA2G2A & -2.55621 & $2.06 \mathrm{E}-43$ & $1.6 \mathrm{E}-41$ & -15.8368 & Down & phospholipase A2 group IIA \\
\hline LCN6 & -2.54437 & $7.91 \mathrm{E}-59$ & $2.16 \mathrm{E}-56$ & -19.5506 & Down & lipocalin 6 \\
\hline CD163 & -2.50965 & $1.12 \mathrm{E}-85$ & $2.6 \mathrm{E}-82$ & -26.1108 & Down & CD163 molecule \\
\hline GNMT & -2.50909 & $2.21 \mathrm{E}-57$ & $5.61 \mathrm{E}-55$ & -19.2036 & Down & glycine $\mathrm{N}$-methyltransferase \\
\hline AQP4 & -2.50556 & $1.63 \mathrm{E}-36$ & $7.51 \mathrm{E}-35$ & -14.1345 & Down & aquaporin 4 \\
\hline SCGN & -2.48857 & 7.7E-44 & $6.13 \mathrm{E}-42$ & -15.9409 & Down & secretagogin, EF-hand calcium binding protein \\
\hline FCN3 & -2.48214 & $5.69 \mathrm{E}-69$ & $3.48 \mathrm{E}-66$ & -21.9932 & Down & $\begin{array}{c}\text { ficolin } 3 \\
\text { solute carrier organic anion transporter family member }\end{array}$ \\
\hline SLCO4A1 & -2.41668 & 4.74E-68 & $2.46 \mathrm{E}-65$ & -21.7703 & Down & $4 \mathrm{~A} 1$ \\
\hline PPEF1 & -2.40843 & $4.16 \mathrm{E}-51$ & $6.54 \mathrm{E}-49$ & -17.6979 & Down & protein phosphatase with EF-hand domain 1 \\
\hline SGPP2 & -2.38709 & $1.41 \mathrm{E}-45$ & $1.31 \mathrm{E}-43$ & -16.3629 & Down & sphingosine-1-phosphate phosphatase 2 \\
\hline SAA1 & -2.36387 & $6.15 \mathrm{E}-14$ & $4.41 \mathrm{E}-13$ & -7.80794 & Down & serum amyloid A1 \\
\hline IL1R2 & -2.33348 & $8.84 \mathrm{E}-47$ & $9.38 \mathrm{E}-45$ & -16.6544 & Down & interleukin 1 receptor type 2 \\
\hline OLAH & -2.32381 & $1.23 \mathrm{E}-49$ & $1.65 \mathrm{E}-47$ & -17.3439 & Down & oleoyl-ACP hydrolase \\
\hline LCN15 & -2.30949 & $1.71 \mathrm{E}-34$ & $6.83 \mathrm{E}-33$ & -13.6252 & Down & lipocalin 15 \\
\hline CYP4Z1 & -2.2978 & 4.89E-54 & $1.03 \mathrm{E}-51$ & -18.4015 & Down & cytochrome P450 family 4 subfamily $\mathrm{Z}$ member 1 \\
\hline Ovos 2 & -2.29611 & $2.76 \mathrm{E}-28$ & $6.99 \mathrm{E}-27$ & -12.0196 & Down & alpha-2-macroglobulin like 1 pseudogene \\
\hline IL10 & -2.26244 & $1.07 \mathrm{E}-46$ & $1.11 \mathrm{E}-44$ & -16.6348 & Down & interleukin 10 \\
\hline CD177 & -2.24129 & $1.27 \mathrm{E}-25$ & $2.55 \mathrm{E}-24$ & -11.3037 & Down & CD177 molecule \\
\hline GALNT15 & -2.23547 & $2.82 \mathrm{E}-69$ & $1.83 \mathrm{E}-66$ & -22.067 & Down & polypeptide $\mathrm{N}$-acetylgalactosaminyltransferase 15 \\
\hline FKBP5 & -2.20125 & $1.02 \mathrm{E}-64$ & 4.52E-62 & -20.9657 & Down & FKBP prolylisomerase 5 \\
\hline HOPX & -2.19678 & $2.33 \mathrm{E}-39$ & $1.3 \mathrm{E}-37$ & -14.842 & Down & HOP homeobox \\
\hline MCEMP1 & -2.16877 & 7.4E-33 & $2.6 \mathrm{E}-31$ & -13.2092 & Down & mast cell expressed membrane protein 1 \\
\hline SYN2 & -2.13215 & $4.46 \mathrm{E}-44$ & $3.61 \mathrm{E}-42$ & -15.9986 & Down & synapsin II \\
\hline SERPINA3 & -2.12094 & $2.93 \mathrm{E}-28$ & 7.39E-27 & -12.0128 & Down & serpin family A member 3 \\
\hline TCF24 & -2.09501 & $6.7 \mathrm{E}-26$ & $1.37 \mathrm{E}-24$ & -11.3795 & Down & transcription factor 24 \\
\hline CFTR & -2.08432 & $2.72 \mathrm{E}-36$ & $1.23 \mathrm{E}-34$ & -14.0784 & Down & $\mathrm{CF}$ transmembrane conductance regulator \\
\hline RARRES1 & -2.08128 & $1.7 \mathrm{E}-44$ & $1.43 \mathrm{E}-42$ & -16.1007 & Down & retinoic acid receptor responder 1 \\
\hline EREG & -2.0761 & $5.3 \mathrm{E}-22$ & $7.89 \mathrm{E}-21$ & -10.2947 & Down & epiregulin \\
\hline LBP & -2.0676 & $1.07 \mathrm{E}-20$ & $1.43 \mathrm{E}-19$ & -9.91761 & Down & lipopolysaccharide binding protein \\
\hline C4orf54 & -2.05065 & $8.08 \mathrm{E}-20$ & $9.99 \mathrm{E}-19$ & -9.66017 & Down & chromosome 4 open reading frame 54 \\
\hline LGI3 & -2.04234 & $5.28 \mathrm{E}-32$ & $1.77 \mathrm{E}-30$ & -12.9903 & Down & leucine rich repeat LGI family member 3 \\
\hline BLM & -2.03762 & $5.04 \mathrm{E}-74$ & $5.51 \mathrm{E}-71$ & -23.2226 & Down & BLM RecQ like helicase \\
\hline SULT1B1 & -2.03126 & $2.66 \mathrm{E}-49$ & $3.5 \mathrm{E}-47$ & -17.263 & Down & sulfotransferase family 1B member 1 \\
\hline C1orf105 & -2.02075 & $2.12 \mathrm{E}-41$ & $1.4 \mathrm{E}-39$ & -15.3444 & Down & $\begin{array}{l}\text { chromosome } 1 \text { open reading frame } 105 \\
\text { ADAM metallopeptidase with thrombospondin type } 1\end{array}$ \\
\hline ADAMTS4 & -2.01588 & $5.48 \mathrm{E}-45$ & $4.87 \mathrm{E}-43$ & -16.2199 & Down & motif 4 \\
\hline HMGCS2 & -2.00935 & $9.11 \mathrm{E}-18$ & $9.44 \mathrm{E}-17$ & -9.04123 & Down & 3-hydroxy-3-methylglutaryl-CoA synthase 2 \\
\hline VSIG4 & -1.98626 & $3.18 \mathrm{E}-76$ & 4.71E-73 & -23.7619 & Down & V-set and immunoglobulin domain containing 4 \\
\hline STAC2 & -1.96935 & $2.46 \mathrm{E}-34$ & $9.76 \mathrm{E}-33$ & -13.5853 & Down & SH3 and cysteine rich domain 2 \\
\hline FGF10 & -1.92961 & $4.3 \mathrm{E}-26$ & $9.02 \mathrm{E}-25$ & -11.4317 & Down & fibroblast growth factor 10 \\
\hline
\end{tabular}




\begin{tabular}{|c|c|c|c|c|c|c|}
\hline LYVE1 & -1.92131 & $1.57 \mathrm{E}-62$ & $5.8 \mathrm{E}-60$ & -20.4397 & Down & lymphatic vessel endothelial hyaluronan receptor 1 \\
\hline LAD1 & -1.91982 & $9.62 \mathrm{E}-41$ & $6.02 \mathrm{E}-39$ & -15.1832 & Down & ladinin 1 \\
\hline WNK3 & -1.9035 & $3.09 \mathrm{E}-61$ & $1.09 \mathrm{E}-58$ & -20.1286 & Down & WNK lysine deficient protein kinase 3 \\
\hline DHRS7C & -1.88942 & $1.04 \mathrm{E}-19$ & $1.28 \mathrm{E}-18$ & -9.62709 & Down & dehydrogenase/reductase 7C \\
\hline NMRAL2P & -1.86141 & $1.01 \mathrm{E}-41$ & $6.86 \mathrm{E}-40$ & -15.4235 & Down & NmrA like redox sensor 2, pseudogene \\
\hline GMNC & -1.83731 & $6.65 \mathrm{E}-29$ & $1.76 \mathrm{E}-27$ & -12.1831 & Down & geminin coiled-coil domain containing \\
\hline METTL7B & -1.83099 & $2.07 \mathrm{E}-40$ & $1.25 \mathrm{E}-38$ & -15.1014 & Down & methyltransferase like 7B \\
\hline PLA2G4F & -1.81396 & $4.24 \mathrm{E}-24$ & $7.58 \mathrm{E}-23$ & -10.8848 & Down & phospholipase A2 group IVF \\
\hline SLC11A1 & -1.8014 & $5.26 \mathrm{E}-44$ & $4.24 \mathrm{E}-42$ & -15.9811 & Down & solute carrier family 11 member 1 \\
\hline LINC00964 & -1.77887 & $1.45 \mathrm{E}-36$ & $6.73 \mathrm{E}-35$ & -14.1472 & Down & long intergenic non-protein coding RNA 964 \\
\hline LINC02207 & -1.76058 & $3.51 \mathrm{E}-29$ & $9.52 \mathrm{E}-28$ & -12.2562 & Down & long intergenic non-protein coding RNA 2207 \\
\hline OVCH1 & -1.75228 & $1.32 \mathrm{E}-37$ & $6.59 \mathrm{E}-36$ & -14.4065 & Down & ovochymase 1 \\
\hline RHBDL3 & -1.74833 & $8.3 \mathrm{E}-31$ & $2.54 \mathrm{E}-29$ & -12.681 & Down & rhomboid like 3 \\
\hline MGST1 & -1.73713 & $2.06 \mathrm{E}-39$ & $1.16 \mathrm{E}-37$ & -14.8552 & Down & microsomal glutathione S-transferase 1 \\
\hline MARCO & -1.7321 & $5.53 \mathrm{E}-16$ & $4.82 \mathrm{E}-15$ & -8.48151 & Down & macrophage receptor with collagenous structure \\
\hline SLC25A18 & -1.69891 & $5.06 \mathrm{E}-39$ & $2.77 \mathrm{E}-37$ & -14.7586 & Down & solute carrier family 25 member 18 \\
\hline MANCR & -1.6978 & $1.89 \mathrm{E}-40$ & $1.15 \mathrm{E}-38$ & -15.1112 & Down & mitotically associated long non coding RNA \\
\hline TBC1D29P & -1.6943 & $1.92 \mathrm{E}-27$ & 4.46E-26 & -11.7954 & Down & TBC1 domain family member 29 , pseudogene \\
\hline IL17RB & -1.68748 & $5.8 \mathrm{E}-43$ & $4.39 \mathrm{E}-41$ & -15.727 & Down & interleukin 17 receptor B \\
\hline C5orf64 & -1.66664 & $9.16 \mathrm{E}-29$ & $2.4 \mathrm{E}-27$ & -12.1463 & Down & chromosome 5 open reading frame 64 \\
\hline TDRD9 & -1.65083 & $3.47 \mathrm{E}-52$ & $5.96 \mathrm{E}-50$ & -17.9571 & Down & tudor domain containing 9 \\
\hline CNTN3 & -1.65075 & $1.17 \mathrm{E}-29$ & $3.28 \mathrm{E}-28$ & -12.3817 & Down & contactin 3 \\
\hline SSTR5 & -1.64589 & $1.42 \mathrm{E}-10$ & $7.2 \mathrm{E}-10$ & -6.60229 & Down & somatostatin receptor 5 \\
\hline FAM155B & -1.64483 & $3.91 \mathrm{E}-31$ & $1.22 \mathrm{E}-29$ & -12.7659 & Down & $\begin{array}{l}\text { family with sequence similarity } 155 \text { member B } \\
\text { transmembrane protein with EGF like and two follistatin }\end{array}$ \\
\hline TMEFF2 & -1.63641 & $9.72 \mathrm{E}-21$ & $1.3 \mathrm{E}-19$ & -9.9302 & Down & like domains 2 \\
\hline SIGLEC9 & -1.61765 & 9.97E-57 & $2.47 \mathrm{E}-54$ & -19.0468 & Down & sialic acid binding Ig like lectin 9 \\
\hline IL18R1 & -1.61068 & $2.84 \mathrm{E}-55$ & $6.41 \mathrm{E}-53$ & -18.698 & Down & interleukin 18 receptor 1 \\
\hline AQP3 & -1.59794 & $1.16 \mathrm{E}-48$ & $1.44 \mathrm{E}-46$ & -17.1093 & Down & aquaporin 3 (Gill blood group) \\
\hline SLC38A8 & -1.59297 & $8.76 \mathrm{E}-15$ & $6.82 \mathrm{E}-14$ & -8.09114 & Down & solute carrier family 38 member 8 \\
\hline TMIGD3 & -1.59103 & $1.26 \mathrm{E}-42$ & $9.18 \mathrm{E}-41$ & -15.6445 & Down & transmembrane and immunoglobulin domain containing 3 \\
\hline MT1A & -1.58793 & $1.47 \mathrm{E}-13$ & $1.02 \mathrm{E}-12$ & -7.67924 & Down & metallothionein $1 \mathrm{~A}$ \\
\hline CA14 & -1.58283 & 5.77E-28 & $1.41 \mathrm{E}-26$ & -11.9346 & Down & carbonic anhydrase 14 \\
\hline $\mathrm{CPM}$ & -1.5817 & $1.23 \mathrm{E}-50$ & $1.8 \mathrm{E}-48$ & -17.5848 & Down & carboxypeptidase $\mathrm{M}$ \\
\hline ETNPPL & -1.55969 & $1.83 \mathrm{E}-29$ & $5.09 \mathrm{E}-28$ & -12.3302 & Down & ethanolamine-phosphate phospho-lyase \\
\hline SLC66A1L & -1.54109 & $1.16 \mathrm{E}-43$ & $9.14 \mathrm{E}-42$ & -15.8978 & Down & solute carrier family 66 member 1 like \\
\hline GPR84 & -1.5373 & $1.18 \mathrm{E}-21$ & $1.71 \mathrm{E}-20$ & -10.1951 & Down & G protein-coupled receptor 84 \\
\hline HOOK1 & -1.53589 & $2.71 \mathrm{E}-43$ & $2.09 \mathrm{E}-41$ & -15.8079 & Down & hook microtubule tethering protein 1 \\
\hline $\mathrm{CHDH}$ & -1.52384 & $2.82 \mathrm{E}-55$ & $6.41 \mathrm{E}-53$ & -18.6987 & Down & choline dehydrogenase \\
\hline SERTM1 & -1.52131 & $7.14 \mathrm{E}-21$ & $9.74 \mathrm{E}-20$ & -9.96917 & Down & serine rich and transmembrane domain containing 1 \\
\hline SHISA3 & -1.51927 & $2.09 \mathrm{E}-36$ & $9.56 \mathrm{E}-35$ & -14.107 & Down & shisa family member 3 \\
\hline PCSK1 & -1.50962 & $2.47 \mathrm{E}-21$ & $3.49 \mathrm{E}-20$ & -10.1028 & Down & proproteinconvertasesubtilisin/kexin type 1 \\
\hline $\mathrm{ADH} 1 \mathrm{~B}$ & -1.49531 & $3.76 \mathrm{E}-35$ & $1.57 \mathrm{E}-33$ & -13.7917 & Down & alcohol dehydrogenase 1B (class I), beta polypeptide \\
\hline
\end{tabular}




\begin{tabular}{|c|c|c|c|c|c|c|}
\hline CATSPERB & -1.48402 & $3.22 \mathrm{E}-35$ & $1.35 \mathrm{E}-33$ & -13.8089 & Down & cation channel sperm associated auxiliary subunit beta \\
\hline $\mathrm{CD} 38$ & -1.48372 & $1.86 \mathrm{E}-52$ & $3.3 \mathrm{E}-50$ & -18.0222 & Down & CD38 molecule \\
\hline POM121L9P & -1.47176 & $1.12 \mathrm{E}-54$ & $2.41 \mathrm{E}-52$ & -18.5546 & Down & POM121 transmembranenucleoporin like 9 , pseudogene \\
\hline LINC01166 & -1.47139 & 3.94E-20 & $5 \mathrm{E}-19$ & -9.75233 & Down & long intergenic non-protein coding RNA 1166 \\
\hline RDH10-AS1 & -1.47137 & $1.52 \mathrm{E}-36$ & 7.04E-35 & -14.142 & Down & RDH10 antisense RNA 1 \\
\hline CACNA1E & -1.46899 & $4.75 \mathrm{E}-19$ & $5.5 \mathrm{E}-18$ & -9.43103 & Down & calcium voltage-gated channel subunit alpha1 $\mathrm{E}$ \\
\hline PAQR5 & -1.45849 & $2.86 \mathrm{E}-37$ & $1.4 \mathrm{E}-35$ & -14.323 & Down & progestin and adipoQ receptor family member 5 \\
\hline LINC02388 & -1.45595 & $2.84 \mathrm{E}-15$ & $2.32 \mathrm{E}-14$ & -8.25187 & Down & long intergenic non-protein coding RNA 2388 \\
\hline LINC01134 & -1.44716 & $4.56 \mathrm{E}-31$ & $1.42 \mathrm{E}-29$ & -12.7486 & Down & long intergenic non-protein coding RNA 1134 \\
\hline HPCAL4 & -1.44324 & $1.12 \mathrm{E}-20$ & $1.49 \mathrm{E}-19$ & -9.91235 & Down & hippocalcin like 4 \\
\hline BMP7 & -1.43955 & $1.41 \mathrm{E}-20$ & $1.85 \mathrm{E}-19$ & -9.88326 & Down & bone morphogenetic protein 7 \\
\hline SERPINE1 & -1.43704 & $5.19 \mathrm{E}-17$ & $5.01 \mathrm{E}-16$ & -8.80674 & Down & serpin family E member 1 \\
\hline KNG1 & -1.43341 & $1.09 \mathrm{E}-20$ & $1.45 \mathrm{E}-19$ & -9.916 & Down & $\begin{array}{l}\text { kininogen } 1 \\
\text { minichromosome maintenance } 10 \text { replication initiation }\end{array}$ \\
\hline MCM10 & -1.42685 & $7.91 \mathrm{E}-27$ & $1.76 \mathrm{E}-25$ & -11.6304 & Down & factor \\
\hline SLC22A16 & -1.41592 & $1.05 \mathrm{E}-21$ & $1.52 \mathrm{E}-20$ & -10.2097 & Down & solute carrier family 22 member 16 \\
\hline LOC105378909 & -1.41396 & $3.53 \mathrm{E}-27$ & $8.05 \mathrm{E}-26$ & -11.7245 & Down & uncharacterized LOC105378909 \\
\hline TMEM151B & -1.41097 & $3.2 \mathrm{E}-11$ & $1.74 \mathrm{E}-10$ & -6.84623 & Down & transmembrane protein $151 \mathrm{~B}$ \\
\hline WNT9B & -1.40828 & $2.89 \mathrm{E}-27$ & $6.65 \mathrm{E}-26$ & -11.7476 & Down & Wnt family member 9B \\
\hline ST6GALNAC3 & -1.4044 & $8.83 \mathrm{E}-77$ & $1.53 \mathrm{E}-73$ & -23.8986 & Down & ST6 N-acetylgalactosaminide alpha-2,6-sialyltransferase 3 \\
\hline ZBTB16 & -1.40189 & $1.08 \mathrm{E}-26$ & $2.37 \mathrm{E}-25$ & -11.594 & Down & zinc finger and BTB domain containing 16 \\
\hline LINC01088 & -1.39856 & $2.94 \mathrm{E}-29$ & $8.01 \mathrm{E}-28$ & -12.2765 & Down & long intergenic non-protein coding RNA 1088 \\
\hline ANPEP & -1.39173 & $1.79 \mathrm{E}-35$ & $7.6 \mathrm{E}-34$ & -13.8727 & Down & alanylaminopeptidase, membrane \\
\hline CHST9 & -1.39105 & $2.86 \mathrm{E}-17$ & $2.83 \mathrm{E}-16$ & -8.88726 & Down & carbohydrate sulfotransferase 9 \\
\hline CHAC2 & -1.39049 & $4.46 \mathrm{E}-51$ & $6.91 \mathrm{E}-49$ & -17.6907 & Down & ChaCcation transport regulator homolog 2 \\
\hline ANKRD2 & -1.38594 & $1.02 \mathrm{E}-21$ & $1.49 \mathrm{E}-20$ & -10.2128 & Down & ankyrin repeat domain 2 \\
\hline EDNRB & -1.37805 & $1.43 \mathrm{E}-45$ & $1.32 \mathrm{E}-43$ & -16.3619 & Down & endothelin receptor type B \\
\hline TMEM132B & -1.37526 & $5.39 \mathrm{E}-29$ & $1.44 \mathrm{E}-27$ & -12.207 & Down & transmembrane protein $132 \mathrm{~B}$ \\
\hline SSTR2 & -1.36986 & $6.6 \mathrm{E}-38$ & $3.34 \mathrm{E}-36$ & -14.4818 & Down & somatostatin receptor 2 \\
\hline TFCP2L1 & -1.36492 & $1.52 \mathrm{E}-30$ & 4.54E-29 & -12.6127 & Down & transcription factor $\mathrm{CP} 2$ like 1 \\
\hline LMAN1L & -1.35734 & $9.77 \mathrm{E}-15$ & $7.57 \mathrm{E}-14$ & -8.07551 & Down & lectin, mannose binding 1 like \\
\hline NSG1 & -1.35624 & $1.61 \mathrm{E}-34$ & $6.43 \mathrm{E}-33$ & -13.6323 & Down & neuronal vesicle trafficking associated 1 \\
\hline SCGB1D2 & -1.34714 & $1.13 \mathrm{E}-14$ & $8.67 \mathrm{E}-14$ & -8.05497 & Down & secretoglobin family $1 \mathrm{D}$ member 2 \\
\hline S1PR3 & -1.33974 & $6.86 \mathrm{E}-68$ & $3.48 \mathrm{E}-65$ & -21.7316 & Down & sphingosine-1-phosphate receptor 3 \\
\hline $\mathrm{HP}$ & -1.33891 & $2.46 \mathrm{E}-11$ & $1.36 \mathrm{E}-10$ & -6.88868 & Down & $\begin{array}{l}\text { haptoglobin } \\
\text { transmembrane O-mannosyltransferase targeting cadherins }\end{array}$ \\
\hline TMTC1 & -1.33154 & $7.96 \mathrm{E}-61$ & $2.58 \mathrm{E}-58$ & -20.0299 & Down & 1 \\
\hline TOGARAM2 & -1.33092 & $1.63 \mathrm{E}-16$ & $1.49 \mathrm{E}-15$ & -8.65076 & Down & TOG array regulator of axonemal microtubules 2 \\
\hline SDR16C5 & -1.32851 & $1.79 \mathrm{E}-22$ & $2.78 \mathrm{E}-21$ & -10.4291 & Down & short chain dehydrogenase/reductase family $16 \mathrm{C}$ member 5 \\
\hline RGR & -1.3272 & 3.63E-16 & $3.22 \mathrm{E}-15$ & -8.54004 & Down & retinal $\mathrm{G}$ protein coupled receptor \\
\hline S100A9 & -1.32587 & $2.6 \mathrm{E}-19$ & $3.08 \mathrm{E}-18$ & -9.50952 & Down & S100 calcium binding protein A9 \\
\hline FCGR3A & -1.32476 & $1.14 \mathrm{E}-35$ & $4.89 \mathrm{E}-34$ & -13.9225 & Down & Fc fragment of IgG receptor IIIa \\
\hline KRT7 & -1.3219 & $3.25 \mathrm{E}-11$ & $1.77 \mathrm{E}-10$ & -6.84385 & Down & keratin 7 \\
\hline HS6ST2 & -1.31832 & $5.38 \mathrm{E}-20$ & $6.76 \mathrm{E}-19$ & -9.71245 & Down & heparansulfate 6-O-sulfotransferase 2 \\
\hline
\end{tabular}




\begin{tabular}{|c|c|c|c|c|c|c|}
\hline SERPINA5 & -1.3169 & $3.35 \mathrm{E}-31$ & $1.06 \mathrm{E}-29$ & -12.7831 & Down & serpin family A member 5 \\
\hline SRARP & -1.31534 & $3.97 \mathrm{E}-17$ & $3.86 \mathrm{E}-16$ & -8.84306 & Down & steroid receptor associated and regulated protein \\
\hline CEP55 & -1.3114 & $5.49 \mathrm{E}-18$ & $5.79 \mathrm{E}-17$ & -9.10864 & Down & centrosomal protein 55 \\
\hline SLC7A11 & -1.30737 & $3.72 \mathrm{E}-21$ & $5.19 \mathrm{E}-20$ & -10.0514 & Down & solute carrier family 7 member 11 \\
\hline ELANE & -1.30624 & $1.4 \mathrm{E}-12$ & $8.75 \mathrm{E}-12$ & -7.33899 & Down & elastase, neutrophil expressed \\
\hline LOC100419170 & -1.30099 & $6.81 \mathrm{E}-16$ & $5.87 \mathrm{E}-15$ & -8.4525 & Down & toll like receptor 2 pseudogene \\
\hline TENT5B & -1.29835 & 4.23E-30 & $1.22 \mathrm{E}-28$ & -12.4969 & Down & terminal nucleotidyltransferase 5B \\
\hline KCNB 1 & -1.29075 & $8.19 \mathrm{E}-36$ & $3.55 \mathrm{E}-34$ & -13.9585 & Down & potassium voltage-gated channel subfamily B member 1 \\
\hline GPRC5A & -1.29031 & $7.12 \mathrm{E}-23$ & $1.16 \mathrm{E}-21$ & -10.5421 & Down & $\mathrm{G}$ protein-coupled receptor class $\mathrm{C}$ group 5 member $\mathrm{A}$ \\
\hline FGF5 & -1.28935 & $1.24 \mathrm{E}-16$ & $1.16 \mathrm{E}-15$ & -8.68752 & Down & fibroblast growth factor 5 \\
\hline CFAP77 & -1.28763 & $5.19 \mathrm{E}-34$ & $1.99 \mathrm{E}-32$ & -13.5033 & Down & cilia and flagella associated protein 77 \\
\hline PDE11A & -1.28742 & $1.21 \mathrm{E}-22$ & $1.92 \mathrm{E}-21$ & -10.4774 & Down & phosphodiesterase $11 \mathrm{~A}$ \\
\hline TMEM178B & -1.28381 & $1.72 \mathrm{E}-36$ & 7.93E-35 & -14.1282 & Down & transmembrane protein $178 \mathrm{~B}$ \\
\hline MATN3 & -1.28258 & $9.51 \mathrm{E}-31$ & $2.89 \mathrm{E}-29$ & -12.6658 & Down & matrilin 3 \\
\hline SBK3 & -1.28125 & $1.17 \mathrm{E}-16$ & $1.09 \mathrm{E}-15$ & -8.69549 & Down & SH3 domain binding kinase family member 3 \\
\hline GRIP1 & -1.27293 & $3.11 \mathrm{E}-18$ & $3.36 \mathrm{E}-17$ & -9.18402 & Down & glutamate receptor interacting protein 1 \\
\hline PART1 & -1.27148 & $6.39 \mathrm{E}-23$ & $1.05 \mathrm{E}-21$ & -10.5554 & Down & prostate androgen-regulated transcript 1 \\
\hline TIMP4 & -1.26931 & $2.11 \mathrm{E}-35$ & $8.86 \mathrm{E}-34$ & -13.8552 & Down & TIMP metallopeptidase inhibitor 4 \\
\hline EHD4-AS1 & -1.26754 & $9.1 \mathrm{E}-30$ & $2.58 \mathrm{E}-28$ & -12.4099 & Down & EHD4 antisense RNA 1 \\
\hline VSTM2L & -1.26748 & $8.09 \mathrm{E}-16$ & $6.92 \mathrm{E}-15$ & -8.4284 & Down & V-set and transmembrane domain containing 2 like \\
\hline RHAG & -1.26165 & $7.36 \mathrm{E}-20$ & $9.13 \mathrm{E}-19$ & -9.67218 & Down & $\mathrm{Rh}$ associated glycoprotein \\
\hline PLIN2 & -1.25946 & $1.41 \mathrm{E}-53$ & $2.89 \mathrm{E}-51$ & -18.2914 & Down & perilipin 2 \\
\hline MYOT & -1.25393 & $2.67 \mathrm{E}-30$ & $7.78 \mathrm{E}-29$ & -12.549 & Down & myotilin \\
\hline LOC100287036 & -1.24828 & $4.78 \mathrm{E}-16$ & $4.2 \mathrm{E}-15$ & -8.50169 & Down & uncharacterized LOC100287036 \\
\hline MEI4 & -1.24458 & $8.2 \mathrm{E}-20$ & $1.01 \mathrm{E}-18$ & -9.65827 & Down & meiotic double-stranded break formation protein 4 \\
\hline NPPC & -1.24339 & $4.79 \mathrm{E}-13$ & $3.16 \mathrm{E}-12$ & -7.50207 & Down & natriuretic peptide $\mathrm{C}$ \\
\hline FMO5 & -1.24005 & 7.97E-24 & $1.4 \mathrm{E}-22$ & -10.8086 & Down & $\begin{array}{l}\text { flavin containing dimethylanilinemonoxygenase } 5 \\
\text { potassium two pore domain channel subfamily K member }\end{array}$ \\
\hline KCNK1 & -1.23892 & $1.6 \mathrm{E}-40$ & $9.84 \mathrm{E}-39$ & -15.1288 & Down & 1 \\
\hline SYT13 & -1.23357 & $1.52 \mathrm{E}-22$ & $2.38 \mathrm{E}-21$ & -10.4493 & Down & synaptotagmin 13 \\
\hline PRODH & -1.22635 & $1.2 \mathrm{E}-21$ & $1.74 \mathrm{E}-20$ & -10.1925 & Down & proline dehydrogenase 1 \\
\hline FMN1 & -1.22607 & $2.26 \mathrm{E}-31$ & $7.21 \mathrm{E}-30$ & -12.8276 & Down & formin 1 \\
\hline LINC02248 & -1.22281 & $5.24 \mathrm{E}-10$ & $2.49 \mathrm{E}-09$ & -6.38341 & Down & long intergenic non-protein coding RNA 2248 \\
\hline DEPDC1B & -1.22028 & $5.87 \mathrm{E}-20$ & $7.36 \mathrm{E}-19$ & -9.70121 & Down & DEP domain containing $1 \mathrm{~B}$ \\
\hline DCXR-DT & -1.21729 & 4.05E-22 & $6.09 \mathrm{E}-21$ & -10.3281 & Down & $\begin{array}{l}\text { DCXR divergent transcript } \\
\text { C3 and PZP like alpha-2-macroglobulin domain containing }\end{array}$ \\
\hline CPAMD8 & -1.21453 & 4.03E-42 & $2.79 \mathrm{E}-40$ & -15.5212 & Down & 8 \\
\hline FPR1 & -1.21425 & $9.03 \mathrm{E}-25$ & $1.71 \mathrm{E}-23$ & -11.0706 & Down & formyl peptide receptor 1 \\
\hline NQO1 & -1.21175 & $9.69 \mathrm{E}-37$ & $4.54 \mathrm{E}-35$ & -14.1908 & Down & $\mathrm{NAD}(\mathrm{P}) \mathrm{H}$ quinone dehydrogenase 1 \\
\hline MT1X & -1.21115 & $1.52 \mathrm{E}-17$ & $1.54 \mathrm{E}-16$ & -8.97267 & Down & metallothionein $1 \mathrm{X}$ \\
\hline GCOM1 & -1.20921 & $2.46 \mathrm{E}-17$ & $2.45 \mathrm{E}-16$ & -8.90776 & Down & GRINL1A complex locus 1 \\
\hline SIGLEC10 & -1.20658 & $4.38 \mathrm{E}-23$ & $7.28 \mathrm{E}-22$ & -10.6014 & Down & sialic acid binding Ig like lectin 10 \\
\hline REELD1 & -1.20551 & $4.1 \mathrm{E}-20$ & $5.2 \mathrm{E}-19$ & -9.74706 & Down & reeler domain containing 1 \\
\hline TMEM63C & -1.20356 & $1.46 \mathrm{E}-12$ & $9.14 \mathrm{E}-12$ & -7.33185 & Down & transmembrane protein $63 \mathrm{C}$ \\
\hline
\end{tabular}




\begin{tabular}{|c|c|c|c|c|c|c|}
\hline CHL1 & -1.19884 & 8.63E-22 & $1.26 \mathrm{E}-20$ & -10.2341 & Down & cell adhesion molecule L1 like \\
\hline FOSL1 & -1.19066 & $2.83 \mathrm{E}-11$ & $1.55 \mathrm{E}-10$ & -6.86606 & Down & FOS like $1, \mathrm{AP}-1$ transcription factor subunit \\
\hline KIAA1549 & -1.18909 & $1.17 \mathrm{E}-44$ & $9.94 \mathrm{E}-43$ & -16.1398 & Down & KIAA1549 \\
\hline ADAMTS9 & -1.18748 & $1.39 \mathrm{E}-47$ & $1.55 \mathrm{E}-45$ & -16.8488 & Down & $\begin{array}{l}\text { ADAM metallopeptidase with thrombospondin type } 1 \\
\text { motif } 9\end{array}$ \\
\hline F13A1 & -1.17752 & $1.45 \mathrm{E}-30$ & 4.33E-29 & -12.6184 & Down & coagulation factor XIII A chain \\
\hline AASS & -1.177 & 7.57E-23 & $1.23 \mathrm{E}-21$ & -10.5345 & Down & aminoadipate-semialdehyde synthase \\
\hline LUCAT1 & -1.17537 & $2.09 \mathrm{E}-19$ & $2.5 \mathrm{E}-18$ & -9.5374 & Down & lung cancer associated transcript 1 \\
\hline CDH16 & -1.17513 & $1.51 \mathrm{E}-15$ & $1.26 \mathrm{E}-14$ & -8.34112 & Down & cadherin 16 \\
\hline ADAMTS5 & -1.17106 & $2.15 \mathrm{E}-29$ & $5.93 \mathrm{E}-28$ & -12.3122 & Down & $\begin{array}{l}\text { ADAM metallopeptidase with thrombospondin type } 1 \\
\text { motif } 5\end{array}$ \\
\hline KCNIP2 & -1.17026 & $9.89 \mathrm{E}-23$ & $1.59 \mathrm{E}-21$ & -10.5018 & Down & potassium voltage-gated channel interacting protein 2 \\
\hline WWC1 & -1.1615 & $2.31 \mathrm{E}-15$ & $1.9 \mathrm{E}-14$ & -8.28103 & Down & WW and $\mathrm{C} 2$ domain containing 1 \\
\hline S100A3 & -1.15808 & $2.16 \mathrm{E}-13$ & $1.48 \mathrm{E}-12$ & -7.62156 & Down & S100 calcium binding protein A3 \\
\hline AGTR1 & -1.15766 & $3.66 \mathrm{E}-28$ & $9.17 \mathrm{E}-27$ & -11.987 & Down & angiotensin II receptor type 1 \\
\hline SERPINF2 & -1.15346 & $1.27 \mathrm{E}-22$ & $2.01 \mathrm{E}-21$ & -10.4714 & Down & serpin family $\mathrm{F}$ member 2 \\
\hline PRRG4 & -1.14332 & $5.89 \mathrm{E}-24$ & $1.04 \mathrm{E}-22$ & -10.8453 & Down & proline rich and Gla domain 4 \\
\hline $\mathrm{TC} 2 \mathrm{~N}$ & -1.14268 & $2.27 \mathrm{E}-26$ & $4.85 \mathrm{E}-25$ & -11.5069 & Down & tandem $\mathrm{C} 2$ domains, nuclear \\
\hline TPO & -1.13971 & $1.9 \mathrm{E}-43$ & $1.48 \mathrm{E}-41$ & -15.8455 & Down & thyroid peroxidase \\
\hline GCKR & -1.13956 & $2.58 \mathrm{E}-13$ & $1.75 \mathrm{E}-12$ & -7.59508 & Down & glucokinase regulator \\
\hline GPR82 & -1.13898 & $3.09 \mathrm{E}-16$ & $2.77 \mathrm{E}-15$ & -8.56224 & Down & G protein-coupled receptor 82 \\
\hline CDC45 & -1.13722 & $7.61 \mathrm{E}-19$ & $8.64 \mathrm{E}-18$ & -9.36946 & Down & cell division cycle 45 \\
\hline HERC2P3 & -1.13576 & $2.68 \mathrm{E}-10$ & $1.32 \mathrm{E}-09$ & -6.49664 & Down & hect domain and RLD 2 pseudogene 3 \\
\hline ANGPTL4 & -1.13308 & 3.75E-09 & $1.63 \mathrm{E}-08$ & -6.04163 & Down & angiopoietin like 4 \\
\hline $\mathrm{KCNA7}$ & -1.13228 & $3.56 \mathrm{E}-12$ & $2.15 \mathrm{E}-11$ & -7.1944 & Down & potassium voltage-gated channel subfamily A member 7 \\
\hline ESRP2 & -1.12695 & $3.32 \mathrm{E}-22$ & $5.04 \mathrm{E}-21$ & -10.3527 & Down & epithelial splicing regulatory protein 2 \\
\hline ART3 & -1.12533 & $1.64 \mathrm{E}-43$ & $1.28 \mathrm{E}-41$ & -15.861 & Down & ADP-ribosyltransferase 3 \\
\hline IL20RA & -1.12045 & $3.43 \mathrm{E}-18$ & $3.69 \mathrm{E}-17$ & -9.17123 & Down & $\begin{array}{l}\text { interleukin } 20 \text { receptor subunit alpha } \\
\text { potassium voltage-gated channel modifier subfamily } S\end{array}$ \\
\hline KCNS2 & -1.12023 & $9.08 \mathrm{E}-15$ & $7.05 \mathrm{E}-14$ & -8.08602 & Down & member 2 \\
\hline MBNL3 & -1.11831 & $3.63 \mathrm{E}-17$ & $3.54 \mathrm{E}-16$ & -8.85536 & Down & muscleblind like splicing regulator 3 \\
\hline GRB 14 & -1.11785 & $4.49 \mathrm{E}-48$ & $5.3 \mathrm{E}-46$ & -16.9673 & Down & growth factor receptor bound protein 14 \\
\hline MELK & -1.11646 & $6.76 \mathrm{E}-13$ & $4.38 \mathrm{E}-12$ & -7.44996 & Down & maternal embryonic leucine zipper kinase \\
\hline NAMPT & -1.11563 & 4.32E-36 & $1.92 \mathrm{E}-34$ & -14.0282 & Down & nicotinamidephosphoribosyltransferase \\
\hline TLR2 & -1.11382 & $1.37 \mathrm{E}-33$ & $5.06 \mathrm{E}-32$ & -13.3964 & Down & toll like receptor 2 \\
\hline ADGRF4 & -1.1107 & 7.39E-09 & $3.09 \mathrm{E}-08$ & -5.92035 & Down & adhesion $\mathrm{G}$ protein-coupled receptor $\mathrm{F} 4$ \\
\hline TTLL6 & -1.10862 & $3.1 \mathrm{E}-17$ & $3.06 \mathrm{E}-16$ & -8.87646 & Down & tubulin tyrosine ligase like 6 \\
\hline KCND3 & -1.10777 & $6.54 \mathrm{E}-58$ & $1.74 \mathrm{E}-55$ & -19.3306 & Down & potassium voltage-gated channel subfamily D member 3 \\
\hline GPSM2 & -1.09924 & $5.94 \mathrm{E}-32$ & $1.98 \mathrm{E}-30$ & -12.9771 & Down & $\begin{array}{l}\text { G protein signaling modulator } 2 \\
\text { calmodulin regulated spectrin associated protein family }\end{array}$ \\
\hline CAMSAP3 & -1.0914 & $2.63 \mathrm{E}-11$ & $1.44 \mathrm{E}-10$ & -6.87822 & Down & member 3 \\
\hline NID1 & -1.08953 & $2 \mathrm{E}-53$ & $3.99 \mathrm{E}-51$ & -18.2549 & Down & nidogen 1 \\
\hline MOG & -1.08574 & $8.19 \mathrm{E}-13$ & $5.26 \mathrm{E}-12$ & -7.42074 & Down & myelin oligodendrocyte glycoprotein \\
\hline PALLD & -1.08474 & $2.46 \mathrm{E}-46$ & $2.47 \mathrm{E}-44$ & -16.5468 & Down & palladin, cytoskeletal associated protein \\
\hline MPP3 & -1.08422 & $7.46 \mathrm{E}-37$ & $3.52 \mathrm{E}-35$ & -14.2192 & Down & membrane palmitoylated protein 3 \\
\hline THBS1 & -1.08344 & 2.37E-19 & $2.82 \mathrm{E}-18$ & -9.52148 & Down & thrombospondin 1 \\
\hline
\end{tabular}




\begin{tabular}{|c|c|c|c|c|c|c|}
\hline SLCO2A1 & -1.0825 & $3.32 \mathrm{E}-35$ & $1.39 \mathrm{E}-33$ & -13.8055 & Down & $\begin{array}{l}\text { solute carrier organic anion transporter family member } \\
2 \mathrm{~A} 1 \\
\text { SPARC (osteonectin), cwcv and kazal like domains }\end{array}$ \\
\hline SPOCK3 & -1.07804 & $2.78 \mathrm{E}-08$ & $1.09 \mathrm{E}-07$ & -5.67797 & Down & proteoglycan 3 \\
\hline CR1 & -1.07745 & $6.04 \mathrm{E}-16$ & $5.23 \mathrm{E}-15$ & -8.46919 & Down & complement $\mathrm{C} 3 \mathrm{~b} / \mathrm{C} 4 \mathrm{~b}$ receptor 1 (Knops blood group) \\
\hline TUBB4A & -1.07702 & 7.72E-19 & $8.77 \mathrm{E}-18$ & -9.36749 & Down & tubulin beta $4 \mathrm{~A}$ class IVa \\
\hline F8 & -1.07543 & $1.03 \mathrm{E}-33$ & $3.85 \mathrm{E}-32$ & -13.4275 & Down & coagulation factor VIII \\
\hline ZNF366 & -1.07245 & $1.55 \mathrm{E}-09$ & $6.99 \mathrm{E}-09$ & -6.19713 & Down & zinc finger protein 366 \\
\hline ADGRD1 & -1.07197 & $3.68 \mathrm{E}-56$ & $8.89 \mathrm{E}-54$ & -18.9109 & Down & adhesion G protein-coupled receptor D1 \\
\hline LINC01844 & -1.06936 & $1.81 \mathrm{E}-20$ & $2.35 \mathrm{E}-19$ & -9.85152 & Down & long intergenic non-protein coding RNA 1844 \\
\hline SLA & -1.06836 & $1.06 \mathrm{E}-25$ & $2.14 \mathrm{E}-24$ & -11.3249 & Down & Src like adaptor \\
\hline DNER & -1.06766 & $5.57 \mathrm{E}-16$ & $4.85 \mathrm{E}-15$ & -8.48051 & Down & delta/notch like EGF repeat containing \\
\hline C20orf197 & -1.06693 & $7.83 \mathrm{E}-15$ & $6.13 \mathrm{E}-14$ & -8.1072 & Down & chromosome 20 open reading frame 197 \\
\hline FAM83F & -1.06644 & $1.85 \mathrm{E}-29$ & $5.14 \mathrm{E}-28$ & -12.3289 & Down & family with sequence similarity 83 member $F$ \\
\hline SSTR5-AS1 & -1.06089 & $8.95 \mathrm{E}-06$ & $2.52 \mathrm{E}-05$ & -4.50452 & Down & SSTR5 antisense RNA 1 \\
\hline VIT & -1.0607 & $1.39 \mathrm{E}-32$ & $4.82 \mathrm{E}-31$ & -13.139 & Down & vitrin \\
\hline LRRC8E & -1.06061 & $2.76 \mathrm{E}-19$ & $3.26 \mathrm{E}-18$ & -9.50137 & Down & leucine rich repeat containing $8 \mathrm{VRAC}$ subunit $\mathrm{E}$ \\
\hline STOX1 & -1.05648 & $1.79 \mathrm{E}-20$ & $2.33 \mathrm{E}-19$ & -9.85271 & Down & storkhead box 1 \\
\hline PKHD1L1 & -1.05526 & $2.52 \mathrm{E}-10$ & $1.24 \mathrm{E}-09$ & -6.50688 & Down & PKHD1 like 1 \\
\hline ALOX5 & -1.05509 & $5.75 \mathrm{E}-39$ & $3.14 \mathrm{E}-37$ & -14.7448 & Down & arachidonate 5-lipoxygenase \\
\hline SMTNL2 & -1.05192 & 4.46E-31 & $1.39 \mathrm{E}-29$ & -12.7511 & Down & smoothelin like 2 \\
\hline SPC24 & -1.05123 & $1.24 \mathrm{E}-28$ & $3.22 \mathrm{E}-27$ & -12.1119 & Down & SPC24 component of NDC80 kinetochore complex \\
\hline OSMR & -1.04998 & $3.8 \mathrm{E}-35$ & $1.58 \mathrm{E}-33$ & -13.7905 & Down & oncostatin $\mathrm{M}$ receptor \\
\hline PPM1E & -1.04982 & $1.48 \mathrm{E}-07$ & $5.31 \mathrm{E}-07$ & -5.35894 & Down & $\begin{array}{l}\text { protein phosphatase, } \mathrm{Mg} 2+/ \mathrm{Mn} 2+\text { dependent } 1 \mathrm{E} \\
\text { SAM domain, SH3 domain and nuclear localization signals }\end{array}$ \\
\hline SAMSN1 & -1.04852 & $2.33 \mathrm{E}-19$ & $2.78 \mathrm{E}-18$ & -9.52335 & Down & 1 \\
\hline CD109 & -1.04808 & $1.53 \mathrm{E}-42$ & $1.1 \mathrm{E}-40$ & -15.6243 & Down & CD109 molecule \\
\hline CBS & -1.04794 & $1.09 \mathrm{E}-28$ & $2.84 \mathrm{E}-27$ & -12.1267 & Down & cystathionine beta-synthase \\
\hline GPR12 & -1.04772 & $2 \mathrm{E}-14$ & $1.51 \mathrm{E}-13$ & -7.97205 & Down & G protein-coupled receptor 12 \\
\hline SYN3 & -1.04745 & $2.11 \mathrm{E}-24$ & $3.86 \mathrm{E}-23$ & -10.969 & Down & synapsin III \\
\hline CCR1 & -1.04606 & $5.34 \mathrm{E}-27$ & $1.2 \mathrm{E}-25$ & -11.6762 & Down & C-C motif chemokine receptor 1 \\
\hline GRB7 & -1.04361 & $2.79 \mathrm{E}-19$ & $3.29 \mathrm{E}-18$ & -9.50014 & Down & growth factor receptor bound protein 7 \\
\hline PPL & -1.04306 & $6.42 \mathrm{E}-43$ & $4.83 \mathrm{E}-41$ & -15.7162 & Down & periplakin \\
\hline LOC100507516 & -1.04141 & $1.94 \mathrm{E}-20$ & $2.52 \mathrm{E}-19$ & -9.84253 & Down & uncharacterized LOC100507516 \\
\hline GPR183 & -1.04045 & 2.19E-20 & $2.83 \mathrm{E}-19$ & -9.827 & Down & G protein-coupled receptor 183 \\
\hline TLCD2 & -1.04031 & $3.05 \mathrm{E}-23$ & $5.12 \mathrm{E}-22$ & -10.6458 & Down & TLC domain containing 2 \\
\hline PTX3 & -1.0381 & $9.31 \mathrm{E}-10$ & 4.3E-09 & -6.28492 & Down & pentraxin 3 \\
\hline KLHL32 & -1.03311 & $1.69 \mathrm{E}-18$ & $1.87 \mathrm{E}-17$ & -9.26454 & Down & kelch like family member 32 \\
\hline ZDHHC20 & -1.03268 & $6.12 \mathrm{E}-07$ & 2.03E-06 & -5.07664 & Down & zinc finger DHHC-type containing 20 \\
\hline CNR1 & -1.03125 & $3.36 \mathrm{E}-14$ & $2.48 \mathrm{E}-13$ & -7.89646 & Down & cannabinoid receptor 1 \\
\hline RPGR & -1.03109 & 2.64E-38 & $1.38 \mathrm{E}-36$ & -14.5809 & Down & retinitis pigmentosaGTPase regulator \\
\hline TFEC & -1.02784 & $2.48 \mathrm{E}-18$ & $2.7 \mathrm{E}-17$ & -9.21407 & Down & transcription factor EC \\
\hline MSR1 & -1.02631 & $2.77 \mathrm{E}-23$ & $4.69 \mathrm{E}-22$ & -10.6573 & Down & macrophage scavenger receptor 1 \\
\hline CDRT1 & -1.02519 & $1.15 \mathrm{E}-19$ & $1.4 \mathrm{E}-18$ & -9.6148 & Down & CMT1A duplicated region transcript 1 \\
\hline FREM2 & -1.02482 & $1.96 \mathrm{E}-09$ & 8.73E-09 & -6.15591 & Down & FRAS1 related extracellular matrix 2 \\
\hline
\end{tabular}




\begin{tabular}{|c|c|c|c|c|c|c|}
\hline F5 & -1.02393 & $6.87 \mathrm{E}-10$ & $3.22 \mathrm{E}-09$ & -6.3371 & Down & coagulation factor $\mathrm{V}$ \\
\hline SMIM9 & -1.01786 & $2.38 \mathrm{E}-19$ & $2.83 \mathrm{E}-18$ & -9.52073 & Down & small integral membrane protein 9 \\
\hline NECTIN1 & -1.01749 & $6.29 \mathrm{E}-46$ & $5.97 \mathrm{E}-44$ & -16.4481 & Down & nectin cell adhesion molecule 1 \\
\hline ZFP57 & -1.01535 & 0.0101 & 0.017165 & -2.5858 & Down & ZFP57 zinc finger protein \\
\hline LINC02289 & -1.01329 & $1.62 \mathrm{E}-28$ & $4.16 \mathrm{E}-27$ & -12.0808 & Down & long intergenic non-protein coding RNA 2289 \\
\hline CDKL5 & -1.01252 & $9.24 \mathrm{E}-06$ & $2.6 \mathrm{E}-05$ & -4.49752 & Down & cyclin dependent kinase like 5 \\
\hline EIF4EBP1 & -1.01195 & $8.78 \mathrm{E}-18$ & $9.12 \mathrm{E}-17$ & -9.04606 & Down & eukaryotic translation initiation factor $4 \mathrm{E}$ binding protein 1 \\
\hline LOC100129434 & -1.0107 & $1.39 \mathrm{E}-21$ & 2.01E-20 & -10.1743 & Down & uncharacterized LOC100129434 \\
\hline ITPKA & -1.01004 & $8.87 \mathrm{E}-11$ & 4.6E-10 & -6.68031 & Down & inositol-trisphosphate 3-kinase A \\
\hline HAS2 & -1.00952 & $1.03 \mathrm{E}-17$ & $1.07 \mathrm{E}-16$ & -9.02455 & Down & hyaluronan synthase 2 \\
\hline PCNT & -1.00784 & 4.48E-52 & 7.63E-50 & -17.9305 & Down & pericentrin \\
\hline NUDT4 & -1.00756 & 4.52E-36 & $2 \mathrm{E}-34$ & -14.0233 & Down & nudix hydrolase 4 \\
\hline ELF3 & -1.00732 & $1.12 \mathrm{E}-10$ & $5.76 \mathrm{E}-10$ & -6.6416 & Down & E74 like ETS transcription factor 3 \\
\hline B3GALT1 & -1.00415 & $1.6 \mathrm{E}-17$ & $1.62 \mathrm{E}-16$ & -8.96561 & Down & beta-1,3-galactosyltransferase 1 \\
\hline SIGLEC14 & -1.0039 & $5.59 \mathrm{E}-10$ & $2.65 \mathrm{E}-09$ & -6.37216 & Down & sialic acid binding Ig like lectin 14 \\
\hline NUDT4B & -0.99985 & $5.54 \mathrm{E}-10$ & 2.63E-09 & -6.37373 & Down & nudix hydrolase 4B \\
\hline CLEC7A & -0.99973 & $9.85 \mathrm{E}-23$ & $1.58 \mathrm{E}-21$ & -10.5023 & Down & C-type lectin domain containing 7A \\
\hline RNF157 & -0.99959 & $1.36 \mathrm{E}-31$ & 4.4E-30 & -12.8846 & Down & ring finger protein 157 \\
\hline STEAP4 & -0.99897 & $2.2 \mathrm{E}-31$ & 7.03E-30 & -12.8307 & Down & $\begin{array}{l}\text { STEAP4 metalloreductase } \\
\text { potassium two pore domain channel subfamily K member }\end{array}$ \\
\hline KCNK3 & -0.99891 & $2.34 \mathrm{E}-20$ & 3.03E-19 & -9.8184 & Down & $\begin{array}{c}3 \\
\text { SAM and HD domain containing deoxynucleoside }\end{array}$ \\
\hline SAMHD1 & -0.99873 & $6.11 \mathrm{E}-53$ & $1.15 \mathrm{E}-50$ & -18.1382 & Down & triphosphate triphosphohydrolase 1 \\
\hline INSYN1 & -0.99843 & $1.37 \mathrm{E}-27$ & $3.22 \mathrm{E}-26$ & -11.8347 & Down & inhibitory synaptic factor 1 \\
\hline INKA2 & -0.99831 & $6.14 \mathrm{E}-61$ & 2.06E-58 & -20.057 & Down & inka box actin regulator 2 \\
\hline BCAT1 & -0.99623 & $1.02 \mathrm{E}-28$ & $2.68 \mathrm{E}-27$ & -12.1336 & Down & branched chain amino acid transaminase 1 \\
\hline SLC5A1 & -0.99614 & $1.53 \mathrm{E}-30$ & $4.56 \mathrm{E}-29$ & -12.6121 & Down & solute carrier family 5 member 1 \\
\hline SLC38A4 & -0.99485 & $9.56 \mathrm{E}-11$ & $4.94 \mathrm{E}-10$ & -6.6679 & Down & solute carrier family 38 member 4 \\
\hline $\mathrm{CSDC} 2$ & -0.99426 & 2.67E-21 & 3.77E-20 & -10.0929 & Down & cold shock domain containing $\mathrm{C} 2$ \\
\hline ETNK2 & -0.99114 & $1.11 \mathrm{E}-30$ & 3.37E-29 & -12.6479 & Down & ethanolamine kinase 2 \\
\hline PHACTR3 & -0.98446 & $3.47 \mathrm{E}-12$ & $2.1 \mathrm{E}-11$ & -7.19855 & Down & phosphatase and actin regulator 3 \\
\hline INKA2-AS1 & -0.98382 & $1.85 \mathrm{E}-30$ & $5.48 \mathrm{E}-29$ & -12.5904 & Down & INKA2 antisense RNA 1 \\
\hline LGR5 & -0.98318 & $2.63 \mathrm{E}-11$ & $1.45 \mathrm{E}-10$ & -6.8778 & Down & leucine rich repeat containing $\mathrm{G}$ protein-coupled receptor 5 \\
\hline LGR6 & -0.98193 & $2.9 \mathrm{E}-23$ & $4.89 \mathrm{E}-22$ & -10.6518 & Down & leucine rich repeat containing $\mathrm{G}$ protein-coupled receptor 6 \\
\hline ADGRF5 & -0.98027 & 7.74E-38 & $3.89 \mathrm{E}-36$ & -14.4646 & Down & adhesion G protein-coupled receptor F5 \\
\hline LOC105370401 & -0.9795 & 2.07E-07 & 7.27E-07 & -5.29359 & Down & $\begin{array}{l}\text { uncharacterized LOC } 105370401 \\
\text { ADAM metallopeptidase with thrombospondin type } 1\end{array}$ \\
\hline ADAMTS15 & -0.97867 & $3.08 \mathrm{E}-41$ & $1.99 \mathrm{E}-39$ & -15.3047 & Down & motif 15 \\
\hline C1QTNF1 & -0.97823 & $6.59 \mathrm{E}-19$ & $7.53 \mathrm{E}-18$ & -9.38821 & Down & $\mathrm{C} 1 \mathrm{q}$ and $\mathrm{TNF}$ related 1 \\
\hline SIGLEC7 & -0.97434 & $1.41 \mathrm{E}-21$ & 2.03E-20 & -10.1729 & Down & sialic acid binding Ig like lectin 7 \\
\hline TRHDE & -0.97406 & 2.27E-09 & $1 \mathrm{E}-08$ & -6.13046 & Down & thyrotropin releasing hormone degrading enzyme \\
\hline LILRA6 & -0.97359 & $2.41 \mathrm{E}-21$ & $3.41 \mathrm{E}-20$ & -10.106 & Down & leukocyte immunoglobulin like receptor A6 \\
\hline SERPINB8 & -0.97086 & 2.03E-34 & $8.05 \mathrm{E}-33$ & -13.6069 & Down & serpin family B member 8 \\
\hline LRRN3 & -0.97031 & $2.16 \mathrm{E}-14$ & $1.62 \mathrm{E}-13$ & -7.96079 & Down & leucine rich repeat neuronal 3 \\
\hline MT1M & -0.96838 & $6.61 \mathrm{E}-09$ & $2.79 \mathrm{E}-08$ & -5.94048 & Down & metallothionein $1 \mathrm{M}$ \\
\hline
\end{tabular}




\begin{tabular}{|c|c|c|c|c|c|c|}
\hline WDR86-AS1 & -0.9683 & $3.6 \mathrm{E}-10$ & 1.74E-09 & -6.44704 & Down & WDR86 antisense RNA 1 \\
\hline PCK1 & -0.96425 & 0.00069 & 0.001457 & -3.42273 & Down & phosphoenolpyruvatecarboxykinase 1 \\
\hline EDN1 & -0.96378 & $1.44 \mathrm{E}-25$ & $2.87 \mathrm{E}-24$ & -11.289 & Down & endothelin 1 \\
\hline KLF10 & -0.96307 & $1.82 \mathrm{E}-29$ & $5.05 \mathrm{E}-28$ & -12.3313 & Down & Kruppel like factor 10 \\
\hline MANEA & -0.96278 & $5.36 \mathrm{E}-17$ & $5.16 \mathrm{E}-16$ & -8.80226 & Down & mannosidaseendo-alpha \\
\hline TUBAL3 & -0.96258 & $6.11 \mathrm{E}-13$ & $3.98 \mathrm{E}-12$ & -7.46512 & Down & tubulin alpha like 3 \\
\hline PMFBP1 & -0.96247 & $6.09 \mathrm{E}-12$ & $3.59 \mathrm{E}-11$ & -7.11034 & Down & polyamine modulated factor 1 binding protein 1 \\
\hline DAAM2-AS1 & -0.96155 & $1.13 \mathrm{E}-30$ & $3.41 \mathrm{E}-29$ & -12.6465 & Down & DAAM2 antisense RNA 1 \\
\hline ABCB1 & -0.96049 & $1.45 \mathrm{E}-23$ & $2.49 \mathrm{E}-22$ & -10.7363 & Down & ATP binding cassette subfamily B member 1 \\
\hline ELL2 & -0.95986 & $1.16 \mathrm{E}-29$ & $3.25 \mathrm{E}-28$ & -12.3828 & Down & elongation factor for RNA polymerase II 2 \\
\hline HIF3A & -0.95866 & $2.09 \mathrm{E}-33$ & 7.63E-32 & -13.3492 & Down & hypoxia inducible factor 3 subunit alpha \\
\hline ZBED6 & -0.95784 & 0.000413 & 0.000904 & -3.56438 & Down & zinc finger BED-type containing 6 \\
\hline GFI1B & -0.95657 & $2.87 \mathrm{E}-12$ & $1.75 \mathrm{E}-11$ & -7.22798 & Down & growth factor independent 1B transcriptional repressor \\
\hline HMOX2 & -0.95588 & $9.44 \mathrm{E}-45$ & $8.14 \mathrm{E}-43$ & -16.1626 & Down & hemeoxygenase 2 \\
\hline TK1 & -0.95442 & $7.38 \mathrm{E}-13$ & 4.77E-12 & -7.43647 & Down & thymidine kinase 1 \\
\hline SLC36A4 & -0.95143 & $6.25 \mathrm{E}-49$ & $8.02 \mathrm{E}-47$ & -17.1738 & Down & solute carrier family 36 member 4 \\
\hline TMEM132C & -0.95116 & $3.19 \mathrm{E}-18$ & $3.45 \mathrm{E}-17$ & -9.18058 & Down & transmembrane protein $132 \mathrm{C}$ \\
\hline STEAP3 & -0.95098 & 3.34E-49 & 4.37E-47 & -17.2393 & Down & STEAP3 metalloreductase \\
\hline PCLAF & -0.9505 & $3.17 \mathrm{E}-10$ & $1.54 \mathrm{E}-09$ & -6.46829 & Down & PCNA clamp associated factor \\
\hline ALOX5AP & -0.94867 & $2.9 \mathrm{E}-25$ & $5.66 \mathrm{E}-24$ & -11.2059 & Down & arachidonate 5-lipoxygenase activating protein \\
\hline SLC1A1 & -0.94735 & $1.64 \mathrm{E}-32$ & $5.67 \mathrm{E}-31$ & -13.1204 & Down & solute carrier family 1 member 1 \\
\hline EHF & -0.94691 & $3.32 \mathrm{E}-10$ & $1.62 \mathrm{E}-09$ & -6.4604 & Down & ETS homologous factor \\
\hline CCDC68 & -0.94642 & $4.3 \mathrm{E}-18$ & $4.58 \mathrm{E}-17$ & -9.14123 & Down & coiled-coil domain containing 68 \\
\hline BCL6 & -0.94633 & $5.81 \mathrm{E}-61$ & $2.01 \mathrm{E}-58$ & -20.0628 & Down & BCL6 transcription repressor \\
\hline SLC31A2 & -0.94625 & $2.68 \mathrm{E}-53$ & $5.31 \mathrm{E}-51$ & -18.224 & Down & solute carrier family 31 member 2 \\
\hline TXNRD1 & -0.94184 & $6.66 \mathrm{E}-33$ & $2.35 \mathrm{E}-31$ & -13.2209 & Down & thioredoxinreductase 1 \\
\hline GGT5 & -0.93863 & $5.73 \mathrm{E}-17$ & $5.5 \mathrm{E}-16$ & -8.79326 & Down & gamma-glutamyltransferase 5 \\
\hline GRAP2 & -0.93849 & $7.28 \mathrm{E}-23$ & $1.19 \mathrm{E}-21$ & -10.5394 & Down & GRB2 related adaptor protein 2 \\
\hline IGSF22 & -0.9363 & $5.2 \mathrm{E}-23$ & $8.57 \mathrm{E}-22$ & -10.5805 & Down & immunoglobulin superfamily member 22 \\
\hline MARVELD2 & -0.93616 & $4.75 \mathrm{E}-29$ & $1.28 \mathrm{E}-27$ & -12.2216 & Down & MARVEL domain containing 2 \\
\hline SLC19A2 & -0.93586 & $3.58 \mathrm{E}-19$ & 4.2E-18 & -9.46764 & Down & solute carrier family 19 member 2 \\
\hline SELE & -0.93559 & $3.88 \mathrm{E}-06$ & $1.15 \mathrm{E}-05$ & -4.68889 & Down & selectin $\mathrm{E}$ \\
\hline LINC01235 & -0.93519 & $2.15 \mathrm{E}-08$ & $8.55 \mathrm{E}-08$ & -5.7253 & Down & long intergenic non-protein coding RNA 1235 \\
\hline RAB39A & -0.93499 & $3 \mathrm{E}-11$ & $1.64 \mathrm{E}-10$ & -6.85672 & Down & RAB39A, member RAS oncogene family \\
\hline ANLN & -0.93394 & $6.42 \mathrm{E}-10$ & $3.02 \mathrm{E}-09$ & -6.3487 & Down & anillin actin binding protein \\
\hline CLSPN & -0.93196 & $9.75 \mathrm{E}-13$ & $6.21 \mathrm{E}-12$ & -7.39409 & Down & claspin \\
\hline ACPP & -0.93112 & $4.27 \mathrm{E}-15$ & $3.43 \mathrm{E}-14$ & -8.19383 & Down & $\begin{array}{l}\text { acid phosphatase, prostate } \\
\text { leucine rich repeats and guanylate kinase domain }\end{array}$ \\
\hline LRGUK & -0.92812 & $1.91 \mathrm{E}-12$ & $1.18 \mathrm{E}-11$ & -7.29067 & Down & containing \\
\hline ARG1 & -0.9274 & $1.06 \mathrm{E}-06$ & $3.42 \mathrm{E}-06$ & -4.96388 & Down & arginase 1 \\
\hline P2RY12 & -0.92637 & $1.78 \mathrm{E}-10$ & $8.9 \mathrm{E}-10$ & -6.56544 & Down & purinergic receptor $\mathrm{P} 2 \mathrm{Y} 12$ \\
\hline ARNTL & -0.92612 & 7.2E-18 & $7.53 \mathrm{E}-17$ & -9.07262 & Down & aryl hydrocarbon receptor nuclear translocator like \\
\hline LINC01684 & -0.92272 & $1.34 \mathrm{E}-13$ & $9.32 \mathrm{E}-13$ & -7.69327 & Down & long intergenic non-protein coding RNA 1684 \\
\hline
\end{tabular}




\begin{tabular}{|c|c|c|c|c|c|c|}
\hline C1orf162 & -0.92206 & $1.85 \mathrm{E}-35$ & $7.8 \mathrm{E}-34$ & -13.8696 & Down & $\begin{array}{l}\text { chromosome } 1 \text { open reading frame } 162 \\
\text { transient receptor potential cation channel subfamily C }\end{array}$ \\
\hline TRPC4 & -0.92014 & $2.7 \mathrm{E}-18$ & $2.94 \mathrm{E}-17$ & -9.20265 & Down & member 4 \\
\hline AIF1L & -0.91594 & $1.75 \mathrm{E}-52$ & 3.13E-50 & -18.0287 & Down & allograft inflammatory factor 1 like \\
\hline KIF18B & -0.91286 & 4.17E-10 & 2.01E-09 & -6.42185 & Down & kinesin family member $18 \mathrm{~B}$ \\
\hline CRISPLD2 & -0.9128 & $1.26 \mathrm{E}-38$ & $6.7 \mathrm{E}-37$ & -14.66 & Down & cysteine rich secretory protein LCCL domain containing 2 \\
\hline AMD1 & -0.91169 & $1.46 \mathrm{E}-48$ & $1.79 \mathrm{E}-46$ & -17.0851 & Down & adenosylmethionine decarboxylase 1 \\
\hline FLT3 & -0.91165 & 2.93E-14 & $2.17 \mathrm{E}-13$ & -7.91632 & Down & fms related tyrosine kinase 3 \\
\hline ARRDC4 & -0.91072 & $3.74 \mathrm{E}-26$ & $7.89 \mathrm{E}-25$ & -11.4482 & Down & arrestin domain containing 4 \\
\hline SLC4A7 & -0.91068 & $3.18 \mathrm{E}-13$ & $2.13 \mathrm{E}-12$ & -7.56366 & Down & solute carrier family 4 member 7 \\
\hline TOP2A & -0.9091 & 2.87E-09 & $1.26 \mathrm{E}-08$ & -6.08903 & Down & DNA topoisomerase II alpha \\
\hline CENPM & -0.90902 & 4.38E-08 & $1.68 \mathrm{E}-07$ & -5.59272 & Down & centromere protein $\mathrm{M}$ \\
\hline S100A8 & -0.90893 & $7.54 \mathrm{E}-10$ & $3.51 \mathrm{E}-09$ & -6.32114 & Down & S100 calcium binding protein A8 \\
\hline SIRPB2 & -0.90766 & $3.38 \mathrm{E}-19$ & $3.98 \mathrm{E}-18$ & -9.47503 & Down & signal regulatory protein beta 2 \\
\hline MEDAG & -0.90694 & 8.83E-23 & $1.43 \mathrm{E}-21$ & -10.5157 & Down & mesenteric estrogen dependent adipogenesis \\
\hline SLC2A1 & -0.90689 & $9.89 \mathrm{E}-45$ & $8.49 \mathrm{E}-43$ & -16.1578 & Down & solute carrier family 2 member 1 \\
\hline SLC52A3 & -0.90653 & $5.43 \mathrm{E}-32$ & $1.82 \mathrm{E}-30$ & -12.9872 & Down & solute carrier family 52 member 3 \\
\hline SOCS3 & -0.90502 & $2.05 \mathrm{E}-10$ & $1.02 \mathrm{E}-09$ & -6.54144 & Down & suppressor of cytokine signaling 3 \\
\hline PDK4 & -0.90267 & $1.31 \mathrm{E}-10$ & $6.69 \mathrm{E}-10$ & -6.61548 & Down & pyruvate dehydrogenase kinase 4 \\
\hline GLUL & -0.90223 & $8.16 \mathrm{E}-46$ & 7.67E-44 & -16.4208 & Down & glutamate-ammonia ligase \\
\hline HPSE & -0.90161 & $2.07 \mathrm{E}-23$ & $3.53 \mathrm{E}-22$ & -10.6928 & Down & heparanase \\
\hline GABRR2 & -0.90116 & $2.86 \mathrm{E}-06$ & 8.66E-06 & -4.75471 & Down & gamma-aminobutyric acid type A receptor rho2 subunit \\
\hline FAM111B & -0.90086 & $1.25 \mathrm{E}-08$ & $5.12 \mathrm{E}-08$ & -5.82455 & Down & family with sequence similarity 111 member B \\
\hline SNORD101 & -0.90003 & $2.16 \mathrm{E}-11$ & 1.19E-10 & -6.90987 & Down & small nucleolar RNA, C/D box 101 \\
\hline WASF1 & -0.89554 & $6.06 \mathrm{E}-27$ & $1.36 \mathrm{E}-25$ & -11.6614 & Down & WASP family member 1 \\
\hline KIF5C & -0.89536 & 4.84E-25 & $9.31 \mathrm{E}-24$ & -11.145 & Down & kinesin family member $5 \mathrm{C}$ \\
\hline MARK3 & -0.89489 & $6.12 \mathrm{E}-82$ & $1.27 \mathrm{E}-78$ & -25.1753 & Down & microtubule affinity regulating kinase 3 \\
\hline SLC30A10 & -0.89439 & $1.02 \mathrm{E}-12$ & $6.49 \mathrm{E}-12$ & -7.38702 & Down & solute carrier family 30 member 10 \\
\hline TGFBR3 & -0.89378 & $5.11 \mathrm{E}-39$ & $2.79 \mathrm{E}-37$ & -14.7576 & Down & transforming growth factor beta receptor 3 \\
\hline FCER1G & -0.89232 & $1.4 \mathrm{E}-26$ & $3.05 \mathrm{E}-25$ & -11.5633 & Down & $\mathrm{Fc}$ fragment of $\mathrm{IgE}$ receptor $\mathrm{Ig}$ \\
\hline KLHL41 & -0.89223 & $5.91 \mathrm{E}-33$ & $2.09 \mathrm{E}-31$ & -13.2341 & Down & kelch like family member 41 \\
\hline EDN2 & -0.89167 & $6.37 \mathrm{E}-09$ & $2.69 \mathrm{E}-08$ & -5.94703 & Down & endothelin 2 \\
\hline CHI3L1 & -0.89162 & 3.32E-05 & $8.66 \mathrm{E}-05$ & -4.20254 & Down & chitinase 3 like 1 \\
\hline SFRP5 & -0.89029 & $1.32 \mathrm{E}-07$ & 4.77E-07 & -5.38124 & Down & secreted frizzled related protein 5 \\
\hline LAPTM5 & -0.88976 & $1.02 \mathrm{E}-22$ & $1.64 \mathrm{E}-21$ & -10.4975 & Down & lysosomal protein transmembrane 5 \\
\hline SLC9A7 & -0.88906 & $6.45 \mathrm{E}-22$ & $9.53 \mathrm{E}-21$ & -10.2702 & Down & solute carrier family 9 member A7 \\
\hline C8orf88 & -0.88787 & $7.65 \mathrm{E}-51$ & $1.14 \mathrm{E}-48$ & -17.6342 & Down & chromosome 8 open reading frame 88 \\
\hline CLEC4G & -0.88685 & $7.21 \mathrm{E}-07$ & 2.37E-06 & -5.04324 & Down & C-type lectin domain family 4 member G \\
\hline GPAT2 & -0.88402 & $1.9 \mathrm{E}-17$ & $1.91 \mathrm{E}-16$ & -8.94253 & Down & glycerol-3-phosphate acyltransferase 2, mitochondrial \\
\hline $\mathrm{SCN} 3 \mathrm{~A}$ & -0.88292 & $8.31 \mathrm{E}-14$ & $5.91 \mathrm{E}-13$ & -7.76375 & Down & sodium voltage-gated channel alpha subunit 3 \\
\hline BANK1 & -0.88095 & $1 \mathrm{E}-10$ & $5.18 \mathrm{E}-10$ & -6.66001 & Down & B cell scaffold protein with ankyrin repeats 1 \\
\hline SEC14L2 & -0.88054 & $1.42 \mathrm{E}-15$ & $1.19 \mathrm{E}-14$ & -8.34963 & Down & SEC14 like lipid binding 2 \\
\hline LANCL3 & -0.87923 & $1.15 \mathrm{E}-10$ & 5.92E-10 & -6.63674 & Down & LanC like 3 \\
\hline
\end{tabular}




\begin{tabular}{|c|c|c|c|c|c|c|}
\hline $\mathrm{E} 2 \mathrm{~F} 2$ & -0.87786 & $2.5 \mathrm{E}-09$ & $1.1 \mathrm{E}-08$ & -6.11349 & Down & E2F transcription factor 2 \\
\hline IL15RA & -0.87627 & $2.9 \mathrm{E}-47$ & $3.17 \mathrm{E}-45$ & -16.7715 & Down & interleukin 15 receptor subunit alpha \\
\hline ACR & -0.87563 & $6.53 \mathrm{E}-15$ & $5.15 \mathrm{E}-14$ & -8.13328 & Down & acrosin \\
\hline ATP2A2 & -0.8755 & $1.39 \mathrm{E}-30$ & 4.18E-29 & -12.6227 & Down & $\begin{array}{c}\text { ATPase sarcoplasmic/endoplasmic reticulum Ca2+ } \\
\text { transporting } 2\end{array}$ \\
\hline MAMDC2 & -0.87509 & $9.15 \mathrm{E}-18$ & $9.49 \mathrm{E}-17$ & -9.04054 & Down & MAM domain containing 2 \\
\hline MYZAP & -0.87372 & $3.64 \mathrm{E}-05$ & $9.46 \mathrm{E}-05$ & -4.18075 & Down & myocardial zonulaadherens protein \\
\hline EBLN2 & -0.87327 & 3.93E-06 & $1.17 \mathrm{E}-05$ & -4.68593 & Down & endogenous Bornavirus like nucleoprotein 2 \\
\hline USP31 & -0.87252 & $1.22 \mathrm{E}-40$ & $7.61 \mathrm{E}-39$ & -15.1575 & Down & ubiquitin specific peptidase 31 \\
\hline LRMDA & -0.87106 & $1.27 \mathrm{E}-21$ & $1.83 \mathrm{E}-20$ & -10.1859 & Down & leucine rich melanocyte differentiation associated \\
\hline GPR4 & -0.87078 & $8.84 \mathrm{E}-33$ & $3.09 \mathrm{E}-31$ & -13.1895 & Down & G protein-coupled receptor 4 \\
\hline OPN4 & -0.87003 & $1.81 \mathrm{E}-11$ & $1.01 \mathrm{E}-10$ & -6.9378 & Down & opsin 4 \\
\hline PPIP5K2 & -0.86979 & $1.84 \mathrm{E}-24$ & $3.38 \mathrm{E}-23$ & -10.9854 & Down & diphosphoinositolpentakisphosphate kinase 2 \\
\hline SNAI3 & -0.86358 & 4.07E-11 & $2.19 \mathrm{E}-10$ & -6.8073 & Down & snail family transcriptional repressor 3 \\
\hline CDCP1 & -0.86318 & $2.13 \mathrm{E}-16$ & $1.94 \mathrm{E}-15$ & -8.6134 & Down & CUB domain containing protein 1 \\
\hline PAPSS2 & -0.86311 & $1.62 \mathrm{E}-26$ & $3.51 \mathrm{E}-25$ & -11.5461 & Down & 3'-phosphoadenosine 5'-phosphosulfate synthase 2 \\
\hline KIF14 & -0.86236 & $6.12 \mathrm{E}-09$ & $2.59 \mathrm{E}-08$ & -5.95432 & Down & kinesin family member 14 \\
\hline LNCOG & -0.86037 & 2.38E-07 & $8.3 \mathrm{E}-07$ & -5.2659 & Down & lncRNAosteogenesis associated \\
\hline FAM107A & -0.85818 & $2.59 \mathrm{E}-40$ & $1.57 \mathrm{E}-38$ & -15.0771 & Down & family with sequence similarity 107 member A \\
\hline ANKRD7 & -0.85782 & $2.72 \mathrm{E}-14$ & $2.02 \mathrm{E}-13$ & -7.92723 & Down & ankyrin repeat domain 7 \\
\hline AKR1C1 & -0.85714 & $6.87 \mathrm{E}-23$ & $1.12 \mathrm{E}-21$ & -10.5464 & Down & aldo-ketoreductase family 1 member $\mathrm{C} 1$ \\
\hline LINC02177 & -0.85669 & 7.6E-08 & $2.83 \mathrm{E}-07$ & -5.48796 & Down & long intergenic non-protein coding RNA 2177 \\
\hline LSAMP & -0.85556 & $9.78 \mathrm{E}-14$ & $6.9 \mathrm{E}-13$ & -7.73966 & Down & limbic system associated membrane protein \\
\hline DOCK9 & -0.8547 & $6.23 \mathrm{E}-22$ & $9.22 \mathrm{E}-21$ & -10.2746 & Down & dedicator of cytokinesis 9 \\
\hline MS4A4A & -0.85425 & $1.02 \mathrm{E}-21$ & $1.48 \mathrm{E}-20$ & -10.2137 & Down & membrane spanning 4-domains $\mathrm{A} 4 \mathrm{~A}$ \\
\hline LINC01128 & -0.85327 & $5.03 \mathrm{E}-32$ & $1.69 \mathrm{E}-30$ & -12.9958 & Down & long intergenic non-protein coding RNA 1128 \\
\hline HK3 & -0.85159 & $2.75 \mathrm{E}-16$ & $2.48 \mathrm{E}-15$ & -8.57828 & Down & hexokinase 3 \\
\hline SNTG2 & -0.84977 & $2.78 \mathrm{E}-16$ & $2.5 \mathrm{E}-15$ & -8.57682 & Down & syntrophin gamma 2 \\
\hline EPB41L4B & -0.84874 & $8.53 \mathrm{E}-24$ & $1.49 \mathrm{E}-22$ & -10.8005 & Down & erythrocyte membrane protein band 4.1 like $4 \mathrm{~B}$ \\
\hline LOC105378721 & -0.84723 & $1.25 \mathrm{E}-26$ & $2.73 \mathrm{E}-25$ & -11.577 & Down & uncharacterized LOC105378721 \\
\hline CALCRL & -0.84699 & $2.1 \mathrm{E}-13$ & $1.43 \mathrm{E}-12$ & -7.62605 & Down & calcitonin receptor like receptor \\
\hline $\mathrm{CTH}$ & -0.84525 & $2.34 \mathrm{E}-27$ & $5.43 \mathrm{E}-26$ & -11.7723 & Down & cystathionine gamma-lyase \\
\hline ANXA3 & -0.84508 & 2.77E-39 & $1.55 \mathrm{E}-37$ & -14.8233 & Down & annexin $\mathrm{A} 3$ \\
\hline NCEH1 & -0.84422 & $1.43 \mathrm{E}-27$ & $3.35 \mathrm{E}-26$ & -11.8296 & Down & neutral cholesterol ester hydrolase 1 \\
\hline RASD1 & -0.84259 & $3.42 \mathrm{E}-06$ & $1.03 \mathrm{E}-05$ & -4.71643 & Down & ras related dexamethasone induced 1 \\
\hline MERTK & -0.84249 & $1.24 \mathrm{E}-28$ & $3.23 \mathrm{E}-27$ & -12.1114 & Down & MER proto-oncogene, tyrosine kinase \\
\hline TCHH & -0.84214 & $3.38 \mathrm{E}-11$ & $1.83 \mathrm{E}-10$ & -6.83748 & Down & trichohyalin \\
\hline APOB & -0.84165 & $1.21 \mathrm{E}-17$ & $1.24 \mathrm{E}-16$ & -9.00323 & Down & apolipoprotein B \\
\hline EPN3 & -0.84144 & $2.21 \mathrm{E}-12$ & $1.36 \mathrm{E}-11$ & -7.26849 & Down & epsin 3 \\
\hline LOC101927858 & -0.84129 & $3.29 \mathrm{E}-13$ & $2.2 \mathrm{E}-12$ & -7.55892 & Down & uncharacterized LOC101927858 \\
\hline ECT2 & -0.83943 & $2.39 \mathrm{E}-17$ & $2.39 \mathrm{E}-16$ & -8.91154 & Down & epithelial cell transforming 2 \\
\hline TMEM100 & -0.83941 & $2.92 \mathrm{E}-15$ & $2.38 \mathrm{E}-14$ & -8.24789 & Down & transmembrane protein 100 \\
\hline MYBL2 & -0.83919 & $1.2 \mathrm{E}-07$ & 4.34E-07 & -5.40031 & Down & MYB proto-oncogene like 2 \\
\hline
\end{tabular}


bioRxiv preprint doi: https://doi.org/10.1101/2021.01.24.428028; this version posted January $26,2021$. The copyright holder for this preprint (which was not certified by peer review) is the author/funder. All rights reserved. No reuse allowed without permission.

\begin{tabular}{ccccccc}
\hline AFF2 & -0.83824 & $1.98 \mathrm{E}-10$ & $9.87 \mathrm{E}-10$ & -6.54735 & Down & $\begin{array}{c}\text { AF4/FMR2 family member 2 } \\
\text { VEPH1 }\end{array}$ \\
RAET1E & -0.83738 & $2.57 \mathrm{E}-11$ & $1.41 \mathrm{E}-10$ & -6.8819 & Down & ventricular zone expressed PH domain containing 1 \\
IRAK3 & -0.83675 & $8.68 \mathrm{E}-17$ & $8.2 \mathrm{E}-16$ & -8.73659 & Down & retinoic acid early transcript 1E \\
ARMC12 & -0.83589 & $1.24 \mathrm{E}-19$ & $1.51 \mathrm{E}-18$ & -9.60519 & Down & interleukin 1 receptor associated kinase 3 \\
HPR & -0.83392 & $6.8 \mathrm{E}-11$ & $3.58 \mathrm{E}-10$ & -6.72376 & Down & armadillo repeat containing 12 \\
MT1JP & -0.83257 & $1.41 \mathrm{E}-06$ & $4.47 \mathrm{E}-06$ & -4.9042 & Down & haptoglobin-related protein \\
PIK3C2A & -0.83111 & $7.57 \mathrm{E}-15$ & $5.93 \mathrm{E}-14$ & -8.11208 & Down & phosphatidylinositol-4-phosphate 3-kinase catalytic \\
subunit type 2 alpha
\end{tabular}

Table 3 The enriched GO terms of the up and down regulated differentially expressed genes

\begin{tabular}{|c|c|c|c|c|c|c|c|c|}
\hline GO ID & CATEGORY & $\begin{array}{c}\text { GO } \\
\text { Name }\end{array}$ & P Value & $\begin{array}{c}\text { FDR } \\
\text { B\&H } \\
\end{array}$ & $\begin{array}{l}\text { FDR } \\
\text { B\&Y }\end{array}$ & Bonferroni & $\begin{array}{c}\text { Gene } \\
\text { Count }\end{array}$ & Gene \\
\hline \multicolumn{9}{|c|}{ Up regulated genes } \\
\hline \multirow[t]{29}{*}{ GO:0022610 } & $\mathrm{BP}$ & biological & $1.32 \mathrm{E}-13$ & $3.37 \mathrm{E}-10$ & $3.08 \mathrm{E}-09$ & $6.75 \mathrm{E}-10$ & 72 & HLA- \\
\hline & & adhesion & & & & & & DQA1,DACT2,CD83 \\
\hline & & & & & & & & ,MDK,UBASH3A,IT \\
\hline & & & & & & & & GBL1,FAP,MFAP4,S \\
\hline & & & & & & & & ERPINE2,NRXN2,C \\
\hline & & & & & & & & OL14A1,CCR7,ALO \\
\hline & & & & & & & & X15,COL1A1,LAMB \\
\hline & & & & & & & & 4,COL8A2,STAB2,C \\
\hline & & & & & & & & OL16A1,COMP,TB \\
\hline & & & & & & & & $\mathrm{X} 21, \mathrm{FERMT} 1, \mathrm{XG}, \mathrm{C}$ \\
\hline & & & & & & & & CDC80,APOA1,POD \\
\hline & & & & & & & & XL2,ZAP70,HAPLN \\
\hline & & & & & & & & 1,TENM4,SKAP1,C \\
\hline & & & & & & & & NTNAP2,PDE5A,CA \\
\hline & & & & & & & & RD11,CTNNA2,SLA \\
\hline & & & & & & & & MF7,АТР1B2,СX3С \\
\hline & & & & & & & & R1,LRRC15,IDO1,M \\
\hline & & & & & & & & YOC,SIGLEC8,ISLR \\
\hline & & & & & & & & „SMOC2,ITGAL,ITG \\
\hline & & & & & & & & B7,FREM1,PTN,KIR \\
\hline & & & & & & & & REL3,NTM,GLI2,FB \\
\hline & & & & & & & & LN7,DPT,NT5E,EC \\
\hline & & & & & & & & M2,LCK,OMG,OPC \\
\hline & & & & & & & & ML,TGFB2,RASGR \\
\hline & & & & & & & & P1,CD2,CD3E,THBS \\
\hline & & & & & & & & 4,CD5,CD6,THY1,TI \\
\hline & & & & & & & & GIT,CD27,CD40LG, \\
\hline & & & & & & & & ROBO2,GREM1,LY \\
\hline & & & & & & & & 9,HBB,LEF1 \\
\hline \multirow[t]{16}{*}{ GO:0002682 } & $\mathrm{BP}$ & regulation & $2.20 \mathrm{E}-10$ & $2.25 \mathrm{E}-07$ & $2.05 \mathrm{E}-06$ & $1.12 \mathrm{E}-06$ & 72 & IL34,HLA- \\
\hline & & of & & & & & & DQA1,ESR1,TLR7,C \\
\hline & & immune & & & & & & D83,IL17D,MDK,UB \\
\hline & & system & & & & & & ASH3A,TNFRSF4,P \\
\hline & & process & & & & & & YHIN1,ZBP1,FCER1 \\
\hline & & & & & & & & A,MS4A2,FCER2,FC \\
\hline & & & & & & & & N1,CCR7,SMPD3,C \\
\hline & & & & & & & & CL24,SCARA3,ALO \\
\hline & & & & & & & & X15,COL1A1,IL31R \\
\hline & & & & & & & & $\mathrm{A}, \mathrm{TBX} 21, \mathrm{XG}, \mathrm{CXCL}$ \\
\hline & & & & & & & & 14,APOA1,ZAP70,S \\
\hline & & & & & & & & H2D1B,SKAP1,PDE \\
\hline & & & & & & & & 5A,CARD11,SLAMF \\
\hline & & & & & & & & 7,CTSG,CX3CR1,ID \\
\hline & & & & & & & & O1,CXCL10,ITGAL, \\
\hline & & & & & & & & ACE,SIT1,ITGB7,PT \\
\hline
\end{tabular}


bioRxiv preprint doi: https://doi.org/10.1101/2021.01.24.428028; this version posted January 26, 2021. The copyright holder for this preprint (which was not certified by peer review) is the author/funder. All rights reserved. No reuse allowed without permission.

GO:0031012

GO:0009986

GO:0005102
$\mathrm{CC}$

extracellul

$1.09 \mathrm{E}-20$

$2.77 \mathrm{E}-18$

$1.89 \mathrm{E}-17 \quad 5.54 \mathrm{E}-18$

ar matrix

cell

surface

$5.07 \mathrm{E}-17 \quad 8.61 \mathrm{E}-15 \quad 5.86 \mathrm{E}-14 \quad 2.58 \mathrm{E}-14$

63

\begin{tabular}{|c|c|c|c|}
\hline $\begin{array}{l}\text { signaling } \\
\text { receptor } \\
\text { binding }\end{array}$ & $1.36 \mathrm{E}-09$ & $5.99 \mathrm{E}-07$ & 4.41E-06 \\
\hline
\end{tabular}

N,TBC1D10C,FCRL 3,BPI,GLI2,KLRB1, NPPA,CAMK4,LCK, TGFB2,RASGRP1,C D1C,CD1E,CD2,CD 3D,CD3E,THBS4,C D3G,CD247,CD5,CD 6,THY1,TIGIT,MS4 A1,CD27,GPR68,CD 40LG,CD48,GREM1, SH2D1A,LEF1,LRR C17

MATN2,COL22A1, MDK,COLQ,MFAP4 ,SERPINE2,HMCN2, AEBP1,FCN1,CMA1 ,CTHRC1,COL14A1, SCARA3,COL1A1,L AMB4,COL8A2,CO L9A1,COL9A2,COL 10A1,MXRA5,FMO D,COL16A1,COMP, CCDC80,APOA1,H APLN1,CTSG,ADA MTSL2,LRRC15,AS PN,MYOC,NDP,SM OC2,FREM1,PTN,SS C5D,SULF1,DPT,NP PA,ADAMTSL1,EC M2,OGN,ITIH5,TGF B2,LEFTY2,EYS,TH BS4,P3H2,LTBP2,G REM1,LUM,LRRC1 7

HYAL4,NRG1,HLADQA1,CD83,TNFRS F4,ITGBL1,FAP,SE RPINE2,FCER1A,M S4A2,FCER2,FCN1, CXCL9,CCR7,IL31R A,SFRP4,STAB2,DU OX2,APOA1,ACKR 4,FCRL6,SCUBE2,C NTNAP2,SLAMF7,C TSG,IL2RB,CX3CR 1,LRRC15,CXCL10, NDP,ITGAL,ACE,IT GB7,GFRA3,PTN,P ROM1,SSC5D,FCRL 3,SULF1,MRC2,NT M,CLEC9A,NT5E,T GFB2,LHCGR,CD1 C,HHIP,CD1E,CD2, CD3D,CD3E,CD3G, CD5,CD6,THY1,TIG IT,MS4A1,CD27,CD 40LG,CD48,ROBO2, GREM1,LY9

IL34,NRG1,HLADQA1,ESR1,GDF6,P ENK,TAC4,KDM5D, IL17D,MDK,ITGBL 1,FAP,SERPINE2,FC ER2,NRXN2,FCN1, CLEC11A,UCHL1,A GTR2,CXCL9,NGEF ,CTHRC1,C1QTNF2, CCL22,CCL24,CXC L11,COL16A1,COM P,WNT10B,WNT9A, 
bioRxiv preprint doi: https://doi.org/10.1101/2021.01.24.428028; this version posted January 26, 2021. The copyright holder for this preprint (which was not certified by peer review) is the author/funder. All rights reserved. No reuse allowed without permission.

$\begin{array}{cllllll}\text { GO:0098772 MF } & \begin{array}{l}\text { molecular } \\ \text { function } \\ \text { regulator }\end{array} & 3.79 \mathrm{E}-04 & 1.59 \mathrm{E}-02 & 1.17 \mathrm{E}-01 & 3.34 \mathrm{E}-01 & 58\end{array}$

CXCL14,APOA1,FC RL6,GNA14,OASL, RASL11B,LRRC15, CXCL10,ADAM18, MYOC,SYTL2,NDP, ACE,GDNF,ITGB7, GFRA3,PTN,LYPD1 ,SCG2,NPPA,NPPB, MCHR1,ECM2,CMT M2,ESM1,LCK,OGN ,TGFB2,LEFTY2,CD 2,CD3E,THBS4,CD3 G,THY1,TIGIT,MS4 A1,C1QTNF9,CD40 LG,LTB,GREM1,SY TL1,LEF1,LGI1 IL34,NRG1,ESR1,G DF6,PENK,TAC4,IL 17D,MDK,KCNIP1,S ERPINE2,MYOZ1,N RXN2,CLEC11A,SC N2B,AGTR2,CXCL9 ,NGEF,CCL22,CCL2 4,CXCL11,HTR2B,P I16,SCG5,WNT10B, WNT9A,CXCL14,A POA1,LRRC55,PPP2 R2B,ATP1B2,CXCL 10,NDP,BIRC7,GDN F,PTN,TBC1D10C,L YPD1,SCG2,NPPA, NPPB,AZIN2,CMT M2,OGN,RGS4,ITIH 5,TGFB2,LEFTY2,R ASGRP1,THBS4,TH Y1,CD27,C1QTNF9, CD40LG,RGS17,LT B,GREM1,LEF1,INK A1 
bioRxiv preprint doi: https://doi.org/10.1101/2021.01.24.428028; this version posted January 26, 2021. The copyright holder for this preprint (which was not certified by peer review) is the author/funder. All rights reserved. No reuse allowed without permission.

\begin{tabular}{|c|c|c|c|c|c|c|c|c|}
\hline GO:0006952 & $\mathrm{BP}$ & $\begin{array}{l}\text { defense } \\
\text { response }\end{array}$ & $1.04 \mathrm{E}-06$ & $1.63 \mathrm{E}-04$ & $1.49 \mathrm{E}-03$ & $5.50 \mathrm{E}-03$ & 65 & $\begin{array}{l}\text { L1,MCEMP1 } \\
\text { SERPINA3,EREG,V } \\
\text { SIG4,TMIGD3,CLE } \\
\text { C7A,RAET1E,CHI3 } \\
\text { L1,F8,CD163,S100A } \\
\text { 8,S100A9,SAA1,FCE } \\
\text { R1G,HP,HPR,AGTR } \\
\text { 1,PLA2G2A,CCR1,F } \\
\text { GR,SERPINF2,ALO } \\
\text { X5,ALOX5AP,IL17 } \\
\text { RB,CNR1,SELE,AD } \\
\text { AMTS4,ANXA3,FP } \\
\text { R1,APOB,SAMHD1, } \\
\text { CR1,FCN3,AQP4,A } \\
\text { RG1,SLC11A1,MAR } \\
\text { CO,IL10,BCL6,IL18 } \\
\text { R1,GGT5,IL1R2,PT } \\
\text { X3,SIGLEC10,KNG } \\
\text { 1,CACNA1E,CD177, } \\
\text { SOCS3,SIGLEC14,A } \\
\text { DAMTS5,LBP,S1PR } \\
\text { 3,EDN1,EDNRB,FO } \\
\text { SL1,THBS1,RNASE } \\
\text { 2,NAMPT,TLR2,SE } \\
\text { RPINE1,ELANE,IR } \\
\text { AK3,ELF3,IL1RL1,C } \\
\text { ALCRL,OSMR }\end{array}$ \\
\hline GO:0031226 & $\mathrm{CC}$ & $\begin{array}{l}\text { intrinsic } \\
\text { componen } \\
\mathrm{t} \text { of } \\
\text { plasma } \\
\text { membrane }\end{array}$ & $1.74 \mathrm{E}-10$ & $4.55 \mathrm{E}-08$ & $3.11 \mathrm{E}-07$ & $9.10 \mathrm{E}-08$ & 74 & $\begin{array}{l}\text { TPO,EREG,OPN4,T } \\
\text { RPC4,CFTR,TMIGD } \\
\text { 3,KCNIP2,CD163,FC } \\
\text { ER1G,SCN3A,AGT } \\
\text { R1,CCR1,C1QTNF1, } \\
\text { MERTK,SYT13,IL17 } \\
\text { RB,CNR1,TRHDE,S } \\
\text { ELE,LRRC8E,FLT3, } \\
\text { SLC4A7,P2RY12,SL } \\
\text { C31A2,CR1,LGR5,A } \\
\text { QP3,AQP4,SLC1A1, } \\
\text { SLC2A1,SLC5A1,M } \\
\text { SR1,SLC11A1,SIGL } \\
\text { EC7,ART3,SLCO2A } \\
\text { 1,ATP2A2,MARCO, } \\
\text { GABR2,SIGLEC9, } \\
\text { SLCO4A1,GPR84,SS } \\
\text { TR2,SSTR5,IL18R1, } \\
\text { LAPTM5,GGT5,SLC } \\
\text { 52A3,LYVE1,KCNA } \\
\text { 7,KCNB1,KCND3,N } \\
\text { ECTIN1,KCNK1,KC } \\
\text { NK3,KCNS2,ADGR } \\
\text { D1,CACNA1E,GPR4 } \\
\text {,GPR12,SLC38A4,G } \\
\text { PR183,GPRC5A,RG } \\
\text { R,S1PR3,RHAG,ED } \\
\text { NRB,TGFBR3,TLR2 } \\
\text {,LGR6,CALCRL,OS } \\
\text { MR,HAS2,CDH16 }\end{array}$ \\
\hline GO:0098805 & $\mathrm{CC}$ & $\begin{array}{l}\text { whole } \\
\text { membrane }\end{array}$ & $1.91 \mathrm{E}-03$ & 4.99E-02 & $3.41 \mathrm{E}-01$ & $9.97 \mathrm{E}-01$ & 51 & $\begin{array}{l}\text { EREG,SYN3,ACP3, } \\
\text { TRPC4,CFTR,CD10 } \\
\text { 9,HMOX2,CD163,F } \\
\text { CER1G,MGST1,PLA } \\
\text { 2G4F,GPAT2,MOG, } \\
\text { CNR1,SELE,ANPEP, } \\
\text { P2RY12,ANXA3,FP } \\
\text { R1,APOB,SCGN,CR } \\
\text { 1,AQP4,SLC1A1,SL } \\
\text { C2A1,ARG1,MSR1, } \\
\text { SLC11A1,NSG1,RA } \\
\text { B39A,MARCO,SIGL } \\
\text { EC9,GPR84,HPSE,L }\end{array}$ \\
\hline
\end{tabular}


bioRxiv preprint doi: https://doi.org/10.1101/2021.01.24.428028; this version posted January 26, 2021. The copyright holder for this preprint (which was not certified by peer review) is the author/funder. All rights reserved. No reuse allowed without permission.

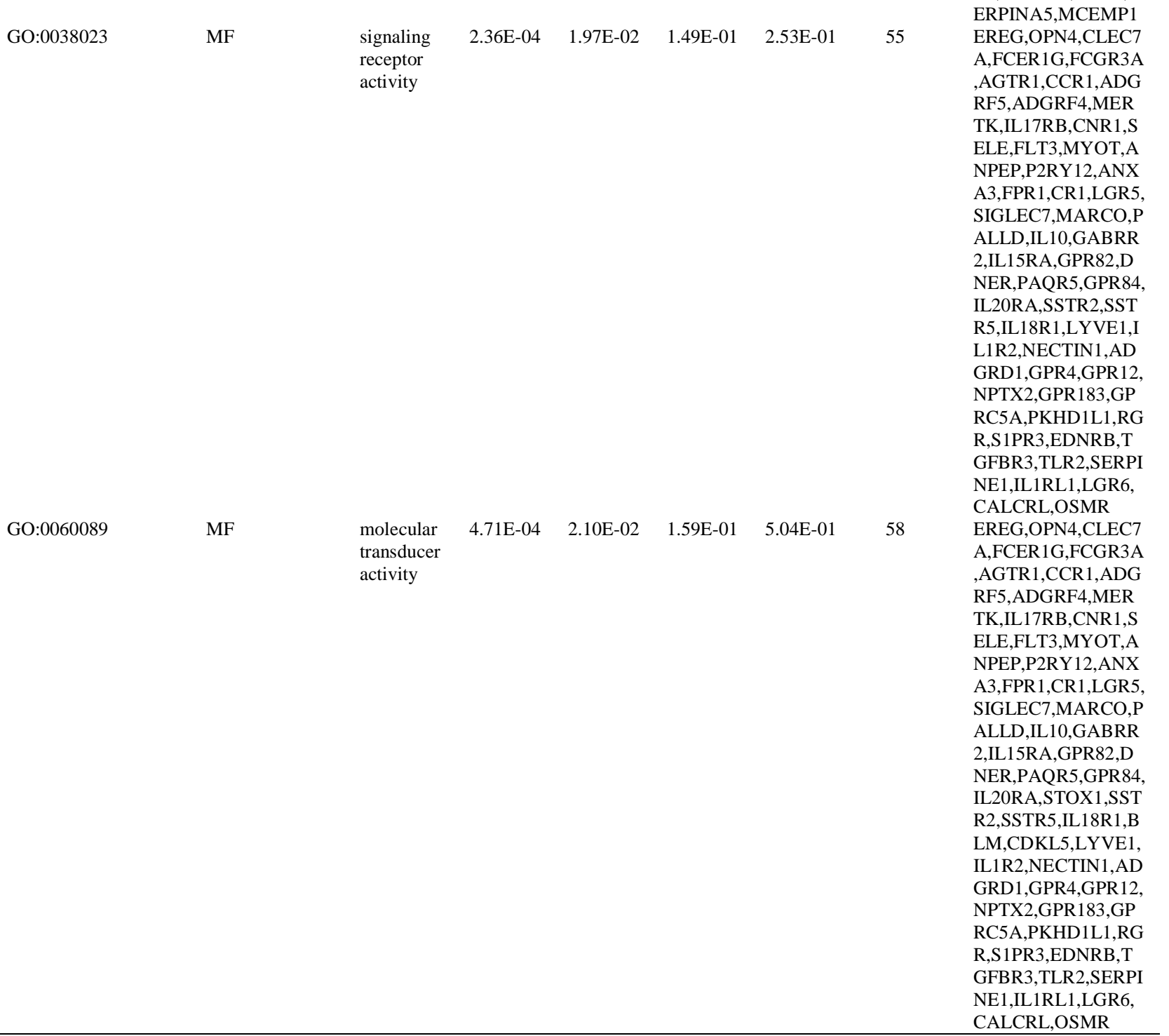

APTM5,KCND3,SY

N2,SLC9A7,WASF1, CD177,SIGLEC14,G RB14,STEAP4,EDN RB,GRIP1,CD38,TL R2,STEAP3,HAS2,S A,FCER1G,FCGR3A TK,IL17RB,CNR1,S NPEP P2RY12,ANX A3,FPR1,CR1,LGR5, IL15RA,GPR82,D NER,PAQR5,GPR84,

L1R2,NECTIN1,AD GPR12, RC5A,PKHD1L1,RG EREG,OPN4,CLEC7 1G,FCGR3A RF5,ADGRF4,MER TK,IL17RB,CNR1,S ,FLT3,MYOT,A A3,FPR1,CR1,LGR5, ALLD,IL10,GABRR 2,IL15RA,GPR82,D R2,SSTR5,IL18R1,B LM,CDKL5,LYVE1, NPTX2,GPR183,GP RC5A,PKHD1L1,RG S CALCRL,OSMR 
bioRxiv preprint doi: https://doi.org/10.1101/2021.01.24.428028; this version posted January $26,2021$. The copyright holder for this preprint (which was not certified by peer review) is the author/funder. All rights reserved. No reuse allowed without permission.

Table 4 The enriched pathway terms of the up and down regulated differentially expressed genes

\begin{tabular}{|c|c|c|c|c|c|c|c|}
\hline Pathway ID & $\begin{array}{c}\text { Pathway } \\
\text { Name }\end{array}$ & P-value & $\begin{array}{l}\text { FDR } \\
\text { B\&H }\end{array}$ & $\begin{array}{l}\text { FDR } \\
\text { B\&Y } \\
\end{array}$ & Bonferroni & $\begin{array}{c}\text { Gene } \\
\text { Count }\end{array}$ & Gene \\
\hline \multicolumn{8}{|c|}{ Up regulated genes } \\
\hline 1270244 & $\begin{array}{l}\text { Extracellular } \\
\text { matrix } \\
\text { organization }\end{array}$ & $3.33 \mathrm{E}-08$ & $1.80 \mathrm{E}-05$ & $1.23 \mathrm{E}-04$ & $1.80 \mathrm{E}-05$ & 24 & $\begin{array}{c}\text { COL22A1,MFAP4,CMA1, } \\
\text { COL14A1,COL1A1,COL8 } \\
\text { A2,COL9A1,COL9A2,CO } \\
\text { L10A1,FMOD,COL16A1, } \\
\text { COMP,HAPLN1,ADAMT } \\
\text { S14,CTSG,ASPN,ITGAL,I } \\
\text { TGB7,CAPN6,TGFB2,P3 } \\
\text { H2,TLL2,LTBP2,LUM }\end{array}$ \\
\hline 1269201 & $\begin{array}{l}\text { Immunoregulat } \\
\text { ory interactions } \\
\text { between a } \\
\text { Lymphoid and } \\
\text { a non- } \\
\text { Lymphoid cell }\end{array}$ & 8.13E-06 & 7.31E-04 & $5.03 \mathrm{E}-03$ & 4.39E-03 & 13 & $\begin{array}{c}\text { SH2D1B,SLAMF7,SIGLE } \\
\text { C8,ITGAL,ITGB7,KLRB1 } \\
\text {,CD1C,CD3D,CD3E,CD3 } \\
\text { G,CD247,CD40LG,SH2D1 } \\
\text { A }\end{array}$ \\
\hline 1269544 & $\begin{array}{l}\text { GPCR ligand } \\
\text { binding }\end{array}$ & $3.92 \mathrm{E}-04$ & $1.51 \mathrm{E}-02$ & $1.04 \mathrm{E}-01$ & $2.12 \mathrm{E}-01$ & 22 & $\begin{array}{c}\text { GNG8,PENK,F2RL2,AGT } \\
\text { R2,APLNR,CXCL9,CCR7, } \\
\text { CXCL11,OXER1,HTR2A, } \\
\text { HTR2B,WNT10B,WNT9A } \\
\text {,ACKR4,CRHBP,S1PR5,F } \\
\text { ZD2,CX3CR1,CXCL10,M } \\
\text { CHR1,LHCGR,GPR68 }\end{array}$ \\
\hline 1268749 & $\begin{array}{c}\text { Metabolism of } \\
\text { Angiotensinoge } \\
n \text { to } \\
\text { Angiotensins }\end{array}$ & $5.26 \mathrm{E}-04$ & $1.85 \mathrm{E}-02$ & $1.27 \mathrm{E}-01$ & 2.84E-01 & 4 & CMA1,CTSG,ACE,GZMH \\
\hline 1269868 & $\begin{array}{l}\text { Muscle } \\
\text { contraction }\end{array}$ & $3.44 \mathrm{E}-02$ & 4.03E-01 & $1.00 \mathrm{E}+00$ & $1.00 \mathrm{E}+00$ & 9 & $\begin{array}{c}\text { KCNIP1,RYR3,SCN2B,A } \\
\text { TP1A4,ATP1B2,MYL1,K } \\
\text { CNK17,NPPA,TNNI1 }\end{array}$ \\
\hline 1269340 & Hemostasis & $6.57 \mathrm{E}-02$ & $5.21 \mathrm{E}-01$ & $1.00 \mathrm{E}+00$ & $1.00 \mathrm{E}+00$ & 20 & $\begin{array}{l}\text { GNG8,CEACAM3,F2RL2, } \\
\text { SERPINE2,APOA1,GNA1 } \\
\text { 4,PDE5A,ATP1B2,IL2RB, } \\
\text { CTSW,ISLR,ITGAL,LCK, } \\
\text { TGFB2,LEFTY2,RASGRP } \\
\text { 1,CD2,P2RX6,CD48,HBB }\end{array}$ \\
\hline 1269171 & $\begin{array}{l}\text { Adaptive } \\
\text { Immune } \\
\text { System }\end{array}$ & $1.32 \mathrm{E}-01$ & $6.87 \mathrm{E}-01$ & $1.00 \mathrm{E}+00$ & $1.00 \mathrm{E}+00$ & 23 & $\begin{array}{c}\text { NRG1,HLA- } \\
\text { DQA1,ZAP70,SH2D1B,C } \\
\text { ARD11,SLAMF7,SIGLEC } \\
\text { 8,ITGAL,ITGB7,ASB18,I } \\
\text { ER3,MRC2,KLRB1,LCK, } \\
\text { RASGRP1,CD1C,CD3D,C } \\
\text { D3E,CD3G,CD247,FBXL } \\
\text { 16,CD40LG,SH2D1A }\end{array}$ \\
\hline \multicolumn{8}{|c|}{ Down regulated genes } \\
\hline 1457780 & $\begin{array}{c}\text { Neutrophil } \\
\text { degranulation }\end{array}$ & $4.82 \mathrm{E}-06$ & $3.14 \mathrm{E}-03$ & $2.22 \mathrm{E}-02$ & $3.14 \mathrm{E}-03$ & 28 & $\begin{array}{c}\text { SERPINA3,HK3,ACP3,H } \\
\text { MOX2,CHI3L1,S100A8,S } \\
\text { 100A9,FCER1G,MGST1, } \\
\text { HP,FGR,ALOX5,ANPEP, } \\
\text { FPR1,CR1,ARG1,SLC11A } \\
\text { 1,SIGLEC9,GPR84,HPSE, } \\
\text { PTX3,CRISPLD2,CD177, } \\
\text { SIGLEC14,RNASE2,TLR } \\
\text { 2,ELANE,MCEMP1 }\end{array}$ \\
\hline 1269907 & $\begin{array}{l}\text { SLC-mediated } \\
\text { transmembrane } \\
\text { transport }\end{array}$ & $6.91 \mathrm{E}-04$ & $4.74 \mathrm{E}-02$ & $3.35 \mathrm{E}-01$ & $4.51 \mathrm{E}-01$ & 16 & $\begin{array}{c}\text { HK3,SLC7A11,SLC4A7,S } \\
\text { LC1A1,SLC2A1,SLC5A1, } \\
\text { SLC11A1,SLC22A16,SLC } \\
\text { O2A1,SLCO4A1,GCKR,L } \\
\text { CN15,SLC9A7,SLC25A18 } \\
\text {,SLC38A4,RHAG }\end{array}$ \\
\hline 1269545 & $\begin{array}{c}\text { Class A/1 } \\
\text { (Rhodopsin-like } \\
\text { receptors) }\end{array}$ & $8.72 \mathrm{E}-04$ & $4.74 \mathrm{E}-02$ & $3.35 \mathrm{E}-01$ & $5.69 \mathrm{E}-01$ & 17 & $\begin{array}{c}\text { OPN4,SAA1,AGTR1,CCR } \\
\text { 1,CNR1,P2RY12,FPR1,SS } \\
\text { TR2,SSTR5,KNG1,GPR4, } \\
\text { GPR183,RGR,S1PR3,EDN } \\
\text { 1,EDN2,EDNRB }\end{array}$ \\
\hline 1269340 & Hemostasis & $2.18 \mathrm{E}-03$ & 7.11E-02 & $5.02 \mathrm{E}-01$ & $1.00 \mathrm{E}+00$ & 26 & SERPINA3,CD109,SLC7A \\
\hline
\end{tabular}


bioRxiv preprint doi: https://doi.org/10.1101/2021.01.24.428028; this version posted January 26, 2021. The copyright holder for this preprint (which was not certified by peer review) is the author/funder. All rights reserved. No reuse allowed without permission.

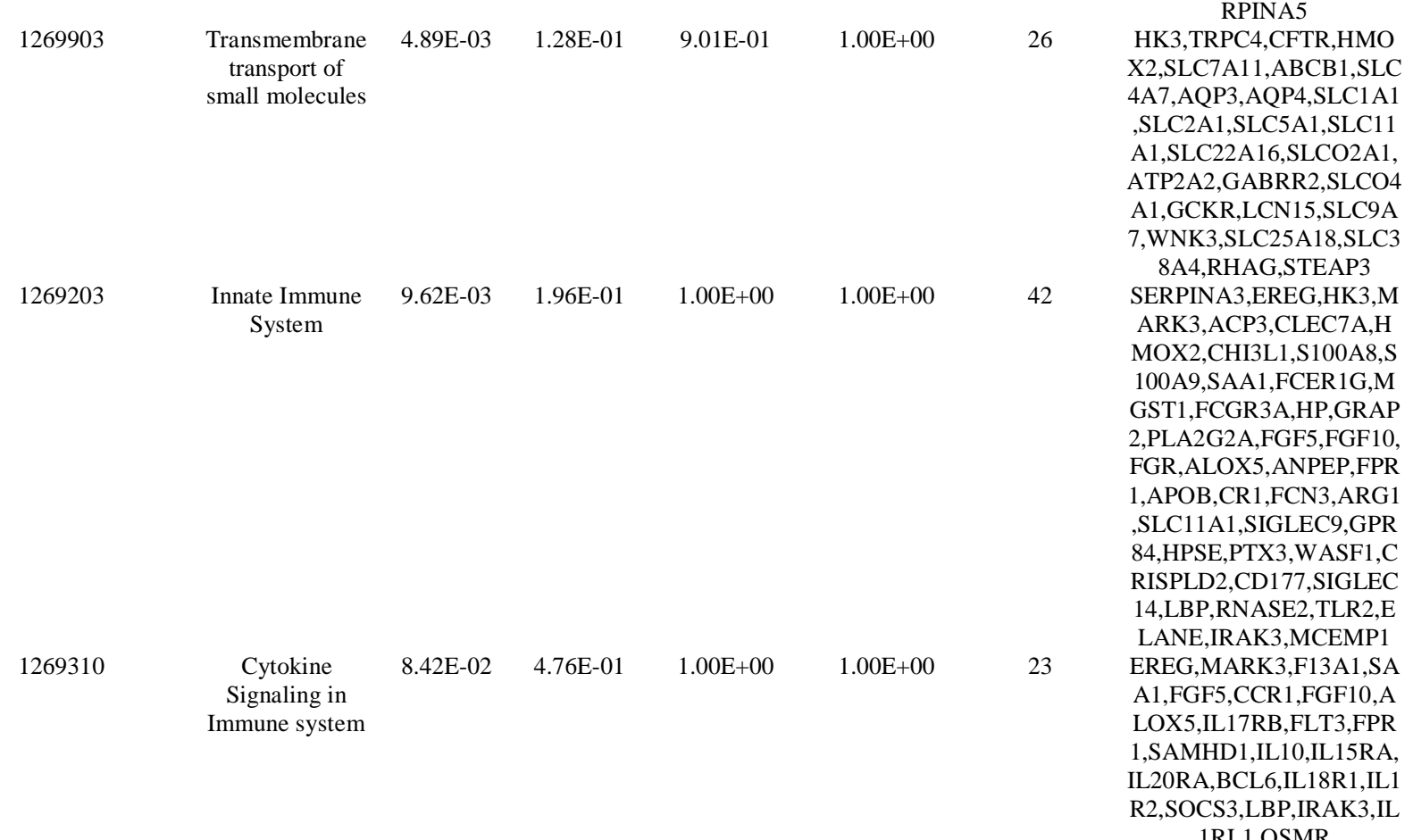

Table 5 Topology table for up and down regulated genes.

\begin{tabular}{cccccc}
\hline Regulation & Node & Degree & Betweenness & Stress & Closeness \\
\hline$U p$ & ESR1 & 1094 & 0.250896 & $7.4 \mathrm{E}+08$ & 0.392769 \\
$\mathrm{Up}$ & PYHIN1 & 342 & 0.054258 & $1.1 \mathrm{E}+08$ & 0.339882 \\
$\mathrm{Up}$ & PPP2R2B & 199 & 0.023115 & 35268762 & 0.346839 \\
$\mathrm{Up}$ & LCK & 162 & 0.033618 & 18589354 & 0.353915 \\
$\mathrm{Up}$ & $\mathrm{TP63}$ & 142 & 0.018577 & 39426608 & 0.319664 \\
$\mathrm{Up}$ & $\mathrm{CD} 247$ & 129 & 0.013832 & 18625274 & 0.317784 \\
$\mathrm{Up}$ & PTN & 105 & 0.016638 & 36892166 & 0.300662 \\
$\mathrm{Up}$ & APLNR & 103 & 0.016611 & 40715208 & 0.288093 \\
$\mathrm{Up}$ & APOA1 & 100 & 0.018834 & 13935332 & 0.315866 \\
$\mathrm{Up}$ & CENPA & 98 & 0.009846 & 31131318 & 0.301786 \\
$\mathrm{Up}$ & SKAP1 & 97 & 0.01599 & 10109482 & 0.313338 \\
$\mathrm{Up}$ & FSCN1 & 88 & 0.010226 & 9387016 & 0.335367 \\
$\mathrm{Up}$ & SCN2B & 86 & 0.01089 & 24233242 & 0.284756 \\
$\mathrm{Up}$ & TMEM30B & 79 & 0.016411 & 10490230 & 0.270807 \\
$\mathrm{Up}$ & FOXS1 & 79 & 0.009408 & 26398078 & 0.293247 \\
$\mathrm{Up}$ & COL1A1 & 76 & 0.010472 & 9315670 & 0.308098 \\
$\mathrm{Up}$ & ZAP70 & 75 & 0.007096 & 5315196 & 0.317614 \\
$\mathrm{Up}$ & UCHL1 & 74 & 0.009753 & 9381024 & 0.331525 \\
$\mathrm{Up}$ & HBB & 72 & 0.009984 & 14209592 & 0.304767 \\
$\mathrm{Up}$ & NRG1 & 70 & 0.01151 & 13449066 & 0.29526 \\
$\mathrm{Up}$ & LEF1 & 61 & 0.007998 & 18260094 & 0.290744 \\
$\mathrm{Up}$ & NT5E & 60 & 0.009599 & 11470634 & 0.301563 \\
$\mathrm{Up}$ & MDK & 59 & 0.006889 & 7533352 & 0.305822 \\
$\mathrm{Up}$ & ISLR & 58 & 0.010139 & 9992806 & 0.294012 \\
$\mathrm{Up}$ & FATE1 & 57 & 0.011609 & 9248788 & 0.281581 \\
$\mathrm{Up}$ & LRRC15 & 56 & 0.010069 & 4772792 & 0.299094 \\
$\mathrm{Up}$ & MATN2 & 54 & 0.004491 & 9580600 & 0.286792 \\
& & & &
\end{tabular}


bioRxiv preprint doi: https://doi.org/10.1101/2021.01.24.428028; this version posted January 26, 2021. The copyright holder for this preprint (which was not certified by peer review) is the author/funder. All rights reserved. No reuse allowed without permission.

\begin{tabular}{|c|c|c|c|c|c|}
\hline Up & LIPH & 54 & 0.008197 & 6873658 & 0.282347 \\
\hline Up & MYOC & 49 & 0.005138 & 12313276 & 0.291029 \\
\hline Up & SCARA3 & 49 & 0.006492 & 11494220 & 0.290151 \\
\hline Up & NPPA & 46 & 0.009502 & 4868574 & 0.307143 \\
\hline Up & CD83 & 43 & 0.005149 & 5484906 & 0.272841 \\
\hline Up & COL14A1 & 41 & 0.006129 & 5699128 & 0.292893 \\
\hline Up & CTSG & 40 & 0.003821 & 1913996 & 0.296155 \\
\hline Up & SFRP4 & 40 & 0.004006 & 7876966 & 0.282518 \\
\hline Up & TRAF3IP3 & 38 & 0.006447 & 4263002 & 0.290602 \\
\hline Up & CLEC11A & 38 & 0.005085 & 3520012 & 0.283596 \\
\hline Up & ATP1B4 & 38 & 0.005722 & 2476482 & 0.245939 \\
\hline Up & CD3E & 37 & 0.003892 & 1537326 & 0.297624 \\
\hline Up & SH2D1A & 37 & 0.003969 & 2117220 & 0.308113 \\
\hline Up & DDX3Y & 37 & 0.003754 & 1632916 & 0.32095 \\
\hline Up & PRPH & 37 & 0.001871 & 1994266 & 0.301494 \\
\hline Up & BIRC7 & 35 & 0.004835 & 2567254 & 0.28549 \\
\hline Up & CARD11 & 35 & 0.002249 & 2510852 & 0.292173 \\
\hline Up & RXRG & 35 & 0.002394 & 7134478 & 0.26225 \\
\hline Up & CCL22 & 34 & 0.005706 & 3916024 & 0.281423 \\
\hline Up & CD27 & 33 & 0.003915 & 2076446 & 0.294263 \\
\hline Up & GZMB & 32 & 0.003277 & 6141522 & 0.285602 \\
\hline Up & THY1 & 32 & 0.003561 & 1793684 & 0.291509 \\
\hline Up & CHRNA3 & 32 & 0.004247 & 3415720 & 0.236631 \\
\hline Up & LSP1 & 32 & 0.003371 & 5734010 & 0.281836 \\
\hline Up & IL2RB & 31 & 0.002351 & 1938172 & 0.305808 \\
\hline Up & HTR2B & 30 & 0.004018 & 2165998 & 0.27434 \\
\hline Up & DLGAP1 & 29 & 0.003816 & 6072882 & 0.277754 \\
\hline Up & TRIM17 & 29 & 0.002943 & 5543810 & 0.275137 \\
\hline Up & CTNNA2 & 29 & 0.003554 & 3511510 & 0.30254 \\
\hline Up & SERPINE2 & 28 & 0.002577 & 3031536 & 0.27426 \\
\hline Up & $\mathrm{CD} 1 \mathrm{E}$ & 28 & 0.003282 & 3419392 & 0.255229 \\
\hline Up & MRC2 & 28 & 0.003395 & 2950548 & 0.296276 \\
\hline Up & C1QTNF2 & 28 & 0.003203 & 2505388 & 0.270147 \\
\hline Up & SH2D1B & 27 & 0.001864 & 1043570 & 0.29028 \\
\hline Up & BRINP1 & 27 & 0.001516 & 4402948 & 0.27726 \\
\hline Up & PDIA2 & 27 & 0.001967 & 2895182 & 0.286453 \\
\hline Up & CHD5 & 27 & 0.001918 & 5223636 & 0.286503 \\
\hline Up & FAP & 27 & 0.003531 & 5820086 & 0.268583 \\
\hline Up & IL31RA & 26 & 0.002073 & 1606954 & 0.263603 \\
\hline Up & GAP43 & 25 & 0.002745 & 2793268 & 0.279858 \\
\hline Up & CD5 & 25 & 0.001695 & 655904 & 0.295861 \\
\hline Up & UBASH3A & 25 & 0.001652 & 1347264 & 0.290951 \\
\hline Up & ROBO2 & 25 & 0.002959 & 3726616 & 0.267048 \\
\hline $\mathrm{Up}$ & ITGB7 & 24 & 0.002686 & 3351660 & 0.276124 \\
\hline Up & HTR2A & 24 & 0.002571 & 2472010 & 0.275833 \\
\hline Up & MOXD1 & 24 & 0.002391 & 2492756 & 0.259926 \\
\hline Up & ASB18 & 24 & $9.77 \mathrm{E}-04$ & 3202162 & 0.273001 \\
\hline Up & CD2 & 23 & 0.002221 & 926408 & 0.287954 \\
\hline Up & BCL11B & 23 & $8.18 \mathrm{E}-04$ & 1888298 & 0.28836 \\
\hline Up & STAT4 & 23 & 0.001786 & 2435506 & 0.277166 \\
\hline $\mathrm{Up}$ & NGEF & 23 & 0.001809 & 1548206 & 0.277636 \\
\hline Up & SMPD3 & 23 & 0.002518 & 2175774 & 0.281 \\
\hline Up & FZD2 & 22 & 0.003673 & 3239390 & 0.250335 \\
\hline Up & DUSP15 & 22 & 0.001253 & 2474532 & 0.284472 \\
\hline Up & CD3D & 21 & 0.001725 & 1111132 & 0.288589 \\
\hline Up & SYT17 & 21 & 0.002549 & 2482574 & 0.285802 \\
\hline Up & FCGR3B & 21 & 0.002748 & 1492022 & 0.282286 \\
\hline Up & EGR2 & 21 & 0.002934 & 3438856 & 0.266406 \\
\hline Up & ZBP1 & 21 & 0.001876 & 2664938 & 0.26006 \\
\hline Up & CAMK4 & 21 & 0.001773 & 3472134 & 0.272716 \\
\hline Up & DMC1 & 20 & 0.002511 & 4659098 & 0.254277 \\
\hline Up & GDNF & 20 & 0.002515 & 3274958 & 0.244751 \\
\hline Up & FCN1 & 20 & 0.002571 & 1243380 & 0.236742 \\
\hline $\mathrm{Up}$ & LUM & 20 & 0.002276 & 1515870 & 0.283903 \\
\hline Up & GZMA & 20 & 0.001051 & 3258230 & 0.276498 \\
\hline Up & TGFB2 & 20 & 0.002259 & 1632566 & 0.277119 \\
\hline Up & SLAMF7 & 20 & 0.00211 & 1035482 & 0.271708 \\
\hline Up & MS4A1 & 20 & 0.002857 & 1169078 & 0.288398 \\
\hline Up & ETV4 & 20 & 0.001747 & 1674080 & 0.301883 \\
\hline $\mathrm{Up}$ & GLI2 & 20 & 0.001398 & 2977194 & 0.285902 \\
\hline
\end{tabular}


bioRxiv preprint doi: https://doi.org/10.1101/2021.01.24.428028; this version posted January $26,2021$. The copyright holder for this preprint (which was not certified by peer review) is the author/funder. All rights reserved. No reuse allowed without permission.

\begin{tabular}{|c|c|c|c|c|c|}
\hline Up & PHLDA1 & 19 & 4.37E-04 & 818256 & 0.298194 \\
\hline Up & COL8A2 & 19 & 0.00147 & 1089762 & 0.273835 \\
\hline Up & GABRD & 19 & 0.002826 & 2629544 & 0.25748 \\
\hline Up & LMF1 & 19 & 0.004342 & 2024228 & 0.265132 \\
\hline Up & F2RL2 & 19 & 0.001554 & 790338 & 0.282933 \\
\hline Up & LYPD1 & 19 & 0.003123 & 3995458 & 0.266276 \\
\hline Up & CAPN6 & 19 & 0.001415 & 3046736 & 0.267802 \\
\hline Up & SOX8 & 19 & 0.003361 & 2763024 & 0.251306 \\
\hline Up & IER3 & 18 & 0.001921 & 3613164 & 0.282982 \\
\hline Up & BEX1 & 18 & 0.001034 & 1286206 & 0.273606 \\
\hline Up & COLQ & 18 & 0.001173 & 1414826 & 0.261234 \\
\hline Up & NTM & 18 & 0.00284 & 2486684 & 0.275102 \\
\hline Up & RPS4Y1 & 18 & 0.001013 & 1200768 & 0.287713 \\
\hline Up & FERMT1 & 18 & 0.001713 & 4279868 & 0.270315 \\
\hline Up & RGS17 & 18 & 0.002928 & 3868106 & 0.249895 \\
\hline Up & TNNI1 & 17 & 0.001349 & 1550004 & 0.266765 \\
\hline Up & MYOZ1 & 17 & 0.00128 & 2111156 & 0.283203 \\
\hline Up & KLHDC8A & 17 & 0.001147 & 7007508 & 0.251036 \\
\hline Up & MYL1 & 17 & $7.90 \mathrm{E}-04$ & 1213666 & 0.289945 \\
\hline Up & $\mathrm{DIO} 2$ & 16 & 0.001161 & 1959228 & 0.279416 \\
\hline Up & ITGAL & 16 & 0.001182 & 1521116 & 0.271527 \\
\hline Up & CRABP2 & 16 & 4.13E-04 & 675182 & 0.272171 \\
\hline Up & HSH2D & 16 & 0.001425 & 889856 & 0.26034 \\
\hline Up & CD48 & 3 & 0 & 0 & 0.265422 \\
\hline Up & CD3G & 2 & 0 & 0 & 0.23833 \\
\hline Up & LY9 & 2 & 0 & 0 & 0.240141 \\
\hline Up & SIT1 & 2 & 0 & 0 & 0.264221 \\
\hline Up & ATP1A4 & 2 & $1.16 \mathrm{E}-04$ & 79140 & 0.235049 \\
\hline Up & FMOD & 2 & $3.96 \mathrm{E}-05$ & 20526 & 0.240707 \\
\hline Up & CCDC80 & 2 & $3.58 \mathrm{E}-05$ & 499704 & 0.288908 \\
\hline Up & CCR7 & 2 & 0 & 0 & 0.244312 \\
\hline Up & KCNIP1 & 1 & 0 & 0 & 0.219995 \\
\hline Up & CD6 & 1 & 0 & 0 & 0.22832 \\
\hline Up & FCRL3 & 1 & 0 & 0 & 0.241062 \\
\hline Up & SERTAD4 & 1 & 0 & 0 & 0.257531 \\
\hline Up & PRF1 & 1 & 0 & 0 & 0.222162 \\
\hline Up & C1QTNF9 & 1 & 0 & 0 & 0.226548 \\
\hline Up & OPCML & 1 & 0 & 0 & 0.215756 \\
\hline Up & ESM1 & 1 & 0 & 0 & 0.213551 \\
\hline Up & CD40LG & 1 & 0 & 0 & 0.240053 \\
\hline Up & S1PR5 & 1 & 0 & 0 & 0.24224 \\
\hline Up & AGTR2 & 1 & 0 & 0 & 0.259256 \\
\hline Up & NPPB & 1 & 0 & 0 & 0.211726 \\
\hline Up & SCG5 & 1 & 0 & 0 & 0.238721 \\
\hline Up & PDE5A & 1 & 0 & 0 & 0.243548 \\
\hline Up & RYR3 & 1 & 0 & 0 & 0.274755 \\
\hline Up & RASEF & 1 & 0 & 0 & 0.274755 \\
\hline Up & PODXL2 & 1 & 0 & 0 & 0.213106 \\
\hline Up & OGN & 1 & 0 & 0 & 0.226548 \\
\hline Up & PLCH2 & 1 & 0 & 0 & 0.238721 \\
\hline Up & SCG2 & 1 & 0 & 0 & 0.267704 \\
\hline Up & P3H2 & 1 & 0 & 0 & 0.207132 \\
\hline Up & C12orf75 & 1 & 0 & 0 & 0.217608 \\
\hline Up & ACE & 1 & 0 & 0 & 0.241159 \\
\hline Up & GNA14 & 1 & 0 & 0 & 0.217608 \\
\hline Up & HDC & 1 & 0 & 0 & 0.216614 \\
\hline Up & CMA1 & 1 & 0 & 0 & 0.226713 \\
\hline Up & CEACAM3 & 1 & 0 & 0 & 0.265519 \\
\hline Down & PCLAF & 817 & 0.135529 & $4.95 \mathrm{E}+08$ & 0.365547 \\
\hline Down & CFTR & 800 & 0.168404 & $4.5 \mathrm{E}+08$ & 0.378823 \\
\hline Down & TK1 & 188 & 0.034997 & 43663230 & 0.331089 \\
\hline Down & ECT2 & 164 & 0.020509 & 39431940 & 0.325989 \\
\hline Down & FKBP5 & 157 & 0.028064 & 15963868 & 0.346288 \\
\hline Down & ANLN & 153 & 0.021564 & 38168832 & 0.325066 \\
\hline Down & ATP2A2 & 148 & 0.027131 & 19656040 & 0.363859 \\
\hline Down & BCL6 & 142 & 0.022279 & 29419916 & 0.314181 \\
\hline Down & TOP2A & 132 & 0.018571 & 16838266 & 0.361426 \\
\hline Down & ZBTB16 & 132 & 0.025165 & 14500206 & 0.349976 \\
\hline Down & S100A9 & 124 & 0.01355 & 11186464 & 0.352219 \\
\hline Down & CEP55 & 123 & 0.019583 & 21505878 & 0.316891 \\
\hline
\end{tabular}


bioRxiv preprint doi: https://doi.org/10.1101/2021.01.24.428028; this version posted January 26, 2021. The copyright holder for this preprint (which was not certified by peer review) is the author/funder. All rights reserved. No reuse allowed without permission.

\begin{tabular}{|c|c|c|c|c|c|}
\hline Down & BLM & 108 & 0.014259 & 18458556 & 0.321945 \\
\hline Down & AGTR1 & 100 & 0.019518 & 14083216 & 0.313564 \\
\hline Down & SAMHD1 & 94 & 0.011463 & 12340270 & 0.337357 \\
\hline Down & S100A8 & 88 & 0.011637 & 8662548 & 0.361486 \\
\hline Down & GRAP2 & 86 & 0.011721 & 16819438 & 0.305936 \\
\hline Down & CBS & 83 & 0.011248 & 20466334 & 0.301591 \\
\hline Down & SOCS3 & 83 & 0.011071 & 9067820 & 0.324888 \\
\hline Down & GFI1B & 80 & 0.011791 & 21469034 & 0.299012 \\
\hline Down & APOB & 78 & 0.014102 & 9290092 & 0.319133 \\
\hline Down & PCK1 & 77 & 0.004102 & 12732476 & 0.305408 \\
\hline Down & MARK3 & 76 & 0.008497 & 19265788 & 0.304512 \\
\hline Down & HMOX2 & 75 & 0.011098 & 15258770 & 0.312053 \\
\hline Down & PCNT & 74 & 0.011297 & 9190430 & 0.312261 \\
\hline Down & PIK3C2A & 69 & 0.005568 & 8768122 & 0.313053 \\
\hline Down & KIF14 & 69 & 0.01035 & 12506564 & 0.304668 \\
\hline Down & WASF1 & 67 & 0.009478 & 18219554 & 0.29633 \\
\hline Down & ARNTL & 65 & 0.00974 & 19494854 & 0.295526 \\
\hline Down & ALOX5 & 65 & 0.010921 & 7343824 & 0.306424 \\
\hline Down & MCM10 & 64 & 0.006773 & 8807396 & 0.306438 \\
\hline Down & THBS1 & 64 & 0.008915 & 6203038 & 0.312694 \\
\hline Down & VSIG4 & 64 & 0.010353 & 10534518 & 0.302037 \\
\hline Down & WWC1 & 64 & 0.007241 & 14604594 & 0.301647 \\
\hline Down & MELK & 63 & 0.008554 & 18629232 & 0.283953 \\
\hline Down & P2RY12 & 63 & 0.008962 & 9063088 & 0.286641 \\
\hline Down & PPL & 62 & 0.007851 & 16137388 & 0.297313 \\
\hline Down & MYBL2 & 59 & 0.006189 & 16766208 & 0.291964 \\
\hline Down & FAM107A & 59 & 0.006172 & 12510302 & 0.289688 \\
\hline Down & GRIP1 & 58 & 0.008069 & 3384760 & 0.320055 \\
\hline Down & ELF3 & 56 & 0.004945 & 7205142 & 0.309118 \\
\hline Down & PALLD & 55 & 0.00509 & 15467012 & 0.293274 \\
\hline Down & CTH & 54 & 0.007754 & 5179060 & 0.296908 \\
\hline Down & EIF4EBP1 & 53 & 0.005367 & 9748852 & 0.303946 \\
\hline Down & KNG1 & 53 & 0.007017 & 4204766 & 0.304243 \\
\hline Down & GLUL & 51 & 0.00728 & 10616752 & 0.30116 \\
\hline Down & SLC2A1 & 51 & 0.004557 & 8307646 & 0.303974 \\
\hline Down & HP & 51 & 0.006741 & 3398298 & 0.314741 \\
\hline Down & RPGR & 50 & 0.004441 & 10097488 & 0.29384 \\
\hline Down & TLR2 & 50 & 0.00754 & 8322330 & 0.294595 \\
\hline Down & GRB7 & 49 & 0.004147 & 4832846 & 0.308113 \\
\hline Down & PPEF1 & 49 & 0.001983 & 3327232 & 0.298276 \\
\hline Down & TXNRD1 & 49 & 0.00627 & 2860122 & 0.328561 \\
\hline Down & NAMPT & 48 & 0.005035 & 10420710 & 0.290538 \\
\hline Down & BMP7 & 47 & 0.007622 & 4442306 & 0.286981 \\
\hline Down & CA14 & 47 & 0.005218 & 4884858 & 0.279189 \\
\hline Down & CCR1 & 46 & 0.008305 & 11217842 & 0.27812 \\
\hline Down & CDC45 & 45 & 0.004479 & 3231162 & 0.30618 \\
\hline Down & ARG1 & 45 & 0.004931 & 2347856 & 0.32381 \\
\hline Down & SPC24 & 43 & 0.005356 & 6589710 & 0.294834 \\
\hline Down & FGR & 43 & 0.003434 & 3020950 & 0.303452 \\
\hline Down & KIF5C & 42 & 0.004876 & 2365086 & 0.319586 \\
\hline Down & IL1R2 & 42 & 0.006825 & 9489620 & 0.289265 \\
\hline Down & SERPINA3 & 42 & 0.005518 & 4047110 & 0.293168 \\
\hline Down & DEPDC1B & 42 & 0.002978 & 9632346 & 0.260838 \\
\hline Down & SLC4A7 & 41 & 0.006314 & 2752106 & 0.316232 \\
\hline Down & SERPINA5 & 41 & 0.003604 & 13750404 & 0.273206 \\
\hline Down & MPP3 & 40 & 0.008262 & 9328402 & 0.297003 \\
\hline Down & NCEH1 & 40 & 0.009405 & 3554728 & 0.304214 \\
\hline Down & SLC1A1 & 38 & 0.008678 & 2278154 & 0.320573 \\
\hline Down & CLSPN & 38 & 0.003668 & 3801300 & 0.294343 \\
\hline Down & BCAT1 & 38 & 0.0052 & 9066238 & 0.269657 \\
\hline Down & MYH6 & 38 & 0.005049 & 1731786 & 0.308578 \\
\hline Down & IL20RA & 37 & 0.005252 & 8769348 & 0.267901 \\
\hline Down & HOOK1 & 37 & 0.005558 & 7195380 & 0.279177 \\
\hline Down & FLT3 & 37 & 0.002948 & 1938440 & 0.292408 \\
\hline Down & ADAMTS4 & 37 & 0.005524 & 2338476 & 0.307519 \\
\hline Down & CAMSAP3 & 36 & 0.003339 & 4795892 & 0.29578 \\
\hline Down & PLA2G2A & 35 & 0.003637 & 1686594 & 0.300565 \\
\hline Down & FOSL1 & 34 & 0.004151 & 10955318 & 0.269402 \\
\hline Down & NQO1 & 34 & 0.001945 & 5351260 & 0.289201 \\
\hline Down & ELANE & 34 & 0.005024 & 2289646 & 0.302834 \\
\hline
\end{tabular}


bioRxiv preprint doi: https://doi.org/10.1101/2021.01.24.428028; this version posted January 26, 2021. The copyright holder for this preprint (which was not certified by peer review) is the author/funder. All rights reserved. No reuse allowed without permission.

\begin{tabular}{|c|c|c|c|c|c|}
\hline Down & KCND3 & 34 & 0.002555 & 9153178 & 0.28203 \\
\hline Down & EPN3 & 34 & 0.005073 & 7423282 & 0.280302 \\
\hline Down & GPR183 & 34 & 0.003642 & 4243792 & 0.256783 \\
\hline Down & CD109 & 34 & 0.006381 & 3655940 & 0.303565 \\
\hline Down & TUBA3E & 34 & 0.003459 & 6711886 & 0.289048 \\
\hline Down & TGFBR3 & 33 & 0.005143 & 1983082 & 0.267386 \\
\hline Down & NID1 & 33 & 0.004536 & 1702236 & 0.311503 \\
\hline Down & STEAP3 & 33 & 0.004665 & 2788716 & 0.285365 \\
\hline Down & AMD1 & 32 & 0.005714 & 3154782 & 0.29099 \\
\hline Down & EDNRB & 31 & 0.003092 & 7273156 & 0.265368 \\
\hline Down & IL17RB & 31 & 0.004227 & 6381040 & 0.261527 \\
\hline Down & SLC19A2 & 30 & 0.004653 & 2505974 & 0.281302 \\
\hline Down & SLC22A16 & 30 & 0.004545 & 3831872 & 0.240618 \\
\hline Down & PHACTR3 & 29 & 0.002193 & 6417862 & 0.280976 \\
\hline Down & LAPTM5 & 29 & 0.003298 & 2735158 & 0.274317 \\
\hline Down & ANGPTL4 & 29 & 0.003467 & 1447446 & 0.325163 \\
\hline Down & PPM1E & 29 & 0.002894 & 5733032 & 0.270427 \\
\hline Down & E2F2 & 28 & 0.002816 & 5508320 & 0.28041 \\
\hline Down & SERPINE1 & 28 & 0.001474 & 2497574 & 0.271302 \\
\hline Down & ACPP & 28 & 0.003084 & 2749550 & 0.291223 \\
\hline Down & KRT7 & 28 & 0.002861 & 1288592 & 0.315774 \\
\hline Down & SERPINB8 & 28 & 0.002944 & 3167812 & 0.28186 \\
\hline Down & FREM2 & 28 & 0.003954 & 3395758 & 0.276661 \\
\hline Down & RNF157 & 28 & 0.002172 & 6196626 & 0.265551 \\
\hline Down & PPIP5K2 & 28 & 0.003886 & 8572108 & 0.270014 \\
\hline Down & F8 & 27 & 0.002839 & 4879016 & 0.274836 \\
\hline Down & TUBAL3 & 27 & 0.002055 & 1052840 & 0.318915 \\
\hline Down & ELL2 & 26 & 0.003971 & 6281508 & 0.255859 \\
\hline Down & GRB14 & 25 & 0.002326 & 3092024 & 0.28378 \\
\hline Down & IRAK3 & 25 & 0.00257 & 6900170 & 0.265897 \\
\hline Down & MANEA & 25 & 0.004508 & 5075608 & 0.263869 \\
\hline Down & CLEC7A & 25 & 0.004246 & 4293212 & 0.277095 \\
\hline Down & KLF10 & 24 & 0.001607 & 3013994 & 0.281339 \\
\hline Down & GNMT & 24 & 0.00165 & 3015768 & 0.269136 \\
\hline Down & ART3 & 24 & 0.002904 & 2401360 & 0.255748 \\
\hline Down & LRRC8E & 24 & 0.003739 & 4188308 & 0.288665 \\
\hline Down & SLA & 23 & 0.001714 & 1003510 & 0.289329 \\
\hline Down & CLEC4G & 23 & 0.002667 & 2376260 & 0.277495 \\
\hline Down & TUBB4A & 5 & $1.28 \mathrm{E}-04$ & 181440 & 0.250652 \\
\hline Down & CD38 & 4 & 0 & 0 & 0.268176 \\
\hline Down & FCGR3A & 4 & $1.01 \mathrm{E}-04$ & 73756 & 0.268385 \\
\hline Down & F5 & 3 & $8.10 \mathrm{E}-07$ & 708 & 0.248641 \\
\hline Down & EHF & 2 & 7.11E-06 & 4180 & 0.254842 \\
\hline Down & KIAA1549 & 2 & $4.16 \mathrm{E}-04$ & 193604 & 0.261391 \\
\hline Down & S100A3 & 2 & $1.84 \mathrm{E}-05$ & 45822 & 0.254376 \\
\hline Down & ADH1B & 2 & $3.40 \mathrm{E}-05$ & 28184 & 0.233546 \\
\hline Down & PAPSS2 & 2 & $1.05 \mathrm{E}-05$ & 8726 & 0.251868 \\
\hline Down & РTX3 & 1 & 0 & 0 & 0.19143 \\
\hline Down & IL15RA & 1 & 0 & 0 & 0.234199 \\
\hline Down & EDN1 & 1 & 0 & 0 & 0.209723 \\
\hline Down & SERPINF2 & 1 & 0 & 0 & 0.232451 \\
\hline Down & ZNF366 & 1 & 0 & 0 & 0.282018 \\
\hline Down & ACR & 1 & 0 & 0 & 0.214588 \\
\hline Down & MATN3 & 1 & 0 & 0 & 0.222881 \\
\hline Down & CNR1 & 1 & 0 & 0 & 0.216205 \\
\hline Down & LBP & 1 & 0 & 0 & 0.240053 \\
\hline Down & ALOX5AP & 1 & 0 & 0 & 0.23456 \\
\hline Down & SCGN & 1 & 0 & 0 & 0.23353 \\
\hline Down & MAMDC2 & 1 & 0 & 0 & 0.248745 \\
\hline Down & CDKL5 & 1 & 0 & 0 & 0.219891 \\
\hline Down & CENPM & 1 & 0 & 0 & 0.231833 \\
\hline Down & KCNIP2 & 1 & 0 & 0 & 0.219995 \\
\hline Down & CPM & 1 & 0 & 0 & 0.24533 \\
\hline Down & GPSM2 & 1 & 0 & 0 & 0.245855 \\
\hline Down & LSAMP & 1 & 0 & 0 & 0.215756 \\
\hline Down & KCNK3 & 1 & 0 & 0 & 0.219353 \\
\hline Down & ALOX15B & 1 & 0 & 0 & 0.234981 \\
\hline Down & ST6GALNAC3 & 1 & 0 & 0 & 0.233263 \\
\hline Down & GPRC5A & 1 & 0 & 0 & 0.274755 \\
\hline Down & SLC31A2 & 1 & 0 & 0 & 0.215287 \\
\hline
\end{tabular}




\begin{tabular}{|c|c|c|c|c|c|}
\hline Down & MARVELD2 & 1 & 0 & 0 & 0.218671 \\
\hline Down & SNTG2 & 1 & 0 & 0 & 0.229 \\
\hline Down & TRHDE & 1 & 0 & 0 & 0.208786 \\
\hline Down & SIGLEC7 & 1 & 0 & 0 & 0.245229 \\
\hline Down & SMTNL2 & 1 & 0 & 0 & 0.265519 \\
\hline Down & ANXA3 & 1 & 0 & 0 & 0.274755 \\
\hline Down & F13A1 & 1 & 0 & 0 & 0.248745 \\
\hline Down & ANKRD7 & 1 & 0 & 0 & 0.233438 \\
\hline Down & KCNS2 & 1 & 0 & 0 & 0.219721 \\
\hline Down & SIGLEC9 & 1 & 0 & 0 & 0.227565 \\
\hline Down & SIGLEC10 & 1 & 0 & 0 & 0.282018 \\
\hline Down & C20orf197 & 1 & 0 & 0 & 0.282018 \\
\hline Down & SCGB1D2 & 1 & 0 & 0 & 0.226548 \\
\hline Down & IL1RL1 & 1 & 0 & 0 & 0.21698 \\
\hline Down & PLIN2 & 1 & 0 & 0 & 0.241935 \\
\hline Down & CD163 & 1 & 0 & 0 & 0.239403 \\
\hline Down & HPR & 1 & 0 & 0 & 0.240053 \\
\hline
\end{tabular}

Table 6 miRNA - target gene and TF - target gene interaction

\begin{tabular}{|c|c|c|c|c|c|c|c|}
\hline Regulation & Target Genes & Degree & MicroRNA & Regulation & Target Genes & Degree & TF \\
\hline Up & FSCN1 & 99 & hsa-mir-4533 & Up & FSCN1 & 62 & ESRRA \\
\hline Up & ESR1 & 72 & hsa-mir-548ac & Up & APOA1 & 48 & RERE \\
\hline Up & TMEM30B & 64 & hsa-mir-548i & Up & COL1A1 & 21 & HMG2OB \\
\hline Up & SCN2B & 46 & hsa-mir-5585-3p & Up & HBB & 16 & THRAP3 \\
\hline Up & CENPA & 35 & hsa-mir-6750-3p & Up & LCK & 15 & ATF1 \\
\hline Up & APOA1 & 22 & hsa-mir-6722-5p & Up & FOXS1 & 14 & YBX1 \\
\hline Up & PPP2R2B & 14 & hsa-mir-149-3p & Up & CENPA & 10 & SAP30 \\
\hline Up & TP63 & 12 & hsa-mir-1178-3p & Up & SCN2B & 5 & RCOR2 \\
\hline Up & PYHIN1 & 5 & hsa-mir-205-3p & Up & TMEM $30 \mathrm{~B}$ & 5 & ZNF24 \\
\hline Up & APLNR & 2 & hsa-mir-10b-5p & Up & APLNR & 4 & FOXJ2 \\
\hline Up & PTN & 1 & hsa-mir-155-5p & Up & NRG1 & 2 & SUZ12 \\
\hline Up & LCK & 1 & hsa-mir-335-5p & Up & PTN & 2 & L3MBTL2 \\
\hline Up & CD247 & 1 & hsa-mir-346 & Up & UCHL1 & 2 & MAZ \\
\hline Down & FKBP5 & 88 & hsa-mir-200c-3p & Up & ESR1 & 1 & EZH2 \\
\hline Down & PCLAF & 62 & hsa-mir-1273g-3p & Up & ZAP70 & 1 & ZFX \\
\hline Down & CEP55 & 57 & hsa-mir-1244 & Down & SOCS3 & 48 & MXD3 \\
\hline Down & ATP2A2 & 55 & hsa-mir-4789-3p & Down & $\mathrm{BCL6}$ & 44 & ARID4B \\
\hline Down & TK1 & 45 & hsa-mir-766-3p & Down & FKBP5 & 43 & $\mathrm{CBFB}$ \\
\hline Down & ZBTB16 & 43 & hsa-mir-1976 & Down & ANLN & 38 & TAF7 \\
\hline Down & SAMHD1 & 26 & hsa-mir-3124-3p & Down & ATP2A2 & 35 & CREM \\
\hline Down & TOP2A & 17 & hsa-mir-186-5p & Down & CBS & 31 & IKZF1 \\
\hline Down & BCL6 & 13 & hsa-mir-339-5p & Down & BLM & 19 & ZNF501 \\
\hline Down & ECT2 & 13 & hsa-mir-132-3p & Down & ЕСТ2 & 15 & KLF16 \\
\hline Down & CFTR & 9 & hsa-mir-145-5p & Down & CEP55 & 10 & FOSL2 \\
\hline Down & S100A9 & 7 & hsa-mir-4679 & Down & GRAP2 & 10 & CEBPD \\
\hline Down & AGTR1 & 5 & hsa-mir-410-3p & Down & ZBTB16 & 4 & TRIM28 \\
\hline Down & ANLN & 5 & hsa-mir-503-5p & Down & S100A8 & 3 & STAT3 \\
\hline \multirow[t]{2}{*}{ Down } & BLM & 3 & hsa-mir-193b-3p & Down & S100A9 & 2 & CEBPG \\
\hline & & & & Down & AGTR1 & 1 & EZH2 \\
\hline
\end{tabular}

Table 7 Docking results of Designed Molecules on Over Expressed Proteins

\begin{tabular}{|c|c|c|c|c|c|c|c|c|c|c|c|c|c|c|c|}
\hline \multirow{2}{*}{$\begin{array}{c}\text { Sl. No/ } \\
\text { Code }\end{array}$} & \multicolumn{3}{|c|}{$\begin{array}{c}\text { Over expressed gene: } \\
\text { ESR1 } \\
\text { PDB: 4PXM } \\
\end{array}$} & \multicolumn{3}{|c|}{$\begin{array}{c}\text { Over expressed gene: } \\
\text { LCK } \\
\text { PDB:1KSW } \\
\end{array}$} & \multicolumn{3}{|c|}{$\begin{array}{c}\text { Over expressed gene: } \\
\text { PPP2R2B } \\
\text { PDB: 2HV7 } \\
\end{array}$} & \multicolumn{3}{|c|}{$\begin{array}{c}\text { Over expressed gene: } \\
\text { PYHIN 1 } \\
\text { PDB: 3VD8 } \\
\end{array}$} & \multicolumn{3}{|c|}{$\begin{array}{c}\text { Over expressed gene: } \\
\text { TP63 } \\
\text { PDB: 6RU6 } \\
\end{array}$} \\
\hline & $\begin{array}{l}\text { Total } \\
\text { Score }\end{array}$ & $\begin{array}{c}\text { Crash } \\
(-V e)\end{array}$ & Polar & $\begin{array}{l}\text { Total } \\
\text { Score }\end{array}$ & $\begin{array}{c}\text { Crash } \\
(-V e)\end{array}$ & Polar & $\begin{array}{l}\text { Total } \\
\text { Score }\end{array}$ & $\begin{array}{c}\text { Crash } \\
(-V e)\end{array}$ & Polar & $\begin{array}{l}\text { Total } \\
\text { Score }\end{array}$ & $\begin{array}{c}\text { Crash } \\
(-V e)\end{array}$ & Polar & $\begin{array}{l}\text { Total } \\
\text { Score }\end{array}$ & $\begin{array}{c}\text { Crash } \\
(-V e)\end{array}$ & Polar \\
\hline HIM1 & 5.097 & -4.375 & & 4.258 & -1.555 & 1.784 & 4.904 & -0.870 & 0.004 & 5.794 & -0.514 & 3.828 & 5.770 & -1.440 & 2.231 \\
\hline HIM2 & 4.057 & -6.172 & 0.039 & 4.624 & -0.997 & 1.959 & 4.906 & -0.468 & 1.517 & 5.052 & -0.780 & 3.415 & 5.414 & -1.529 & 2.444 \\
\hline HIM3 & 5.353 & -5.309 & 0.161 & 4.578 & -1.492 & 1.790 & 5.042 & -1.845 & 1.073 & 5.680 & -0.804 & 3.956 & 5.350 & -1.170 & 2.316 \\
\hline HIM4 & 3.976 & -5.132 & 0.167 & 3.839 & -1.635 & 1.196 & 6.328 & -1.172 & 1.128 & 4.966 & -0.666 & 1.818 & 5.627 & -1.416 & 2.320 \\
\hline HIM5 & 2.707 & -7.759 & 0.179 & 4.067 & -0.997 & 1.987 & 5.254 & -0.674 & 1.618 & 4.563 & -1.068 & 2.935 & 5.698 & -1.240 & 2.485 \\
\hline HIM6 & 5.948 & -3.902 & 1.796 & 5.229 & -0.707 & 3.656 & 6.766 & -1.424 & 1.858 & 6.670 & -0.941 & 5.519 & 6.218 & -1.468 & 2.578 \\
\hline
\end{tabular}


bioRxiv preprint doi: https://doi.org/10.1101/2021.01.24.428028; this version posted January $26,2021$. The copyright holder for this preprint

(which was not certified by peer review) is the author/funder. All rights reserved. No reuse allowed without permission.

\begin{tabular}{|c|c|c|c|c|c|c|c|c|c|c|c|c|c|c|c|}
\hline HIM7 & 5.019 & -7.055 & 0.203 & 4.382 & -2.443 & 3.329 & 6.028 & -0.629 & 1.660 & 5.374 & -1.876 & 0.670 & 6.627 & -1.484 & 2.579 \\
\hline HIM8 & 4.429 & -3.983 & 0.344 & 4.150 & -4.382 & 4.210 & 6.794 & -1.279 & 1.129 & 5.468 & -0.769 & 3.444 & 5.842 & -2.088 & 2.272 \\
\hline HIM9 & 3.722 & -5.956 & 0.197 & 4.051 & -2.006 & 0.002 & 6.116 & -0.597 & 1.717 & 5.407 & -0.565 & 1.370 & 5.877 & -2.054 & 0.792 \\
\hline HIM10 & 6.771 & -3.977 & 1.836 & 5.176 & -3.512 & 4.023 & 5.332 & -1.378 & 3.349 & 6.071 & -0.923 & 3.854 & 5.825 & -0.966 & 3.672 \\
\hline HIM11 & 3.775 & -6.079 & 0.898 & 6.998 & -2.086 & 3.842 & 8.678 & -1.065 & 2.876 & 5.087 & -0.881 & 1.854 & 5.948 & -1.015 & 1.202 \\
\hline HIM12 & 0.190 & -8.149 & 0.022 & 5.302 & -2.305 & 3.475 & 5.227 & -1.636 & 0.710 & 7.322 & -1.128 & 4.099 & 6.237 & -2.562 & 2.171 \\
\hline HIM13 & 4.523 & -4.537 & 0.014 & 4.840 & -0.664 & 3.305 & 6.181 & -2.966 & 3.523 & 5.281 & -0.503 & 3.981 & 5.905 & -1.136 & 2.218 \\
\hline HIM14 & 5.247 & -3.183 & 0.000 & 4.888 & -1.296 & 2.563 & 5.037 & -0.377 & 1.647 & 7.057 & -0.799 & 4.256 & 6.116 & -1.366 & 2.438 \\
\hline HIM15 & 4.633 & -4.173 & 0.180 & 3.756 & -0.710 & 2.072 & 5.188 & -1.559 & 1.143 & 5.570 & -1.125 & 3.718 & 6.238 & -1.708 & 2.443 \\
\hline HIM16 & 4.588 & -2.883 & 0.000 & 6.027 & -1.099 & 3.903 & 5.606 & -0.987 & 4.197 & 5.661 & -0.926 & 2.751 & 7.263 & -1.533 & 4.212 \\
\hline HIM17 & 3.944 & -4.806 & 0.236 & 5.329 & -0.590 & 2.798 & 4.830 & -1.682 & 1.617 & 6.234 & -0.830 & 3.912 & 5.366 & -1.257 & 3.022 \\
\hline HTZ1 & 0.593 & -7.518 & 0 & 4.221 & -0.692 & 1.975 & 3.993 & -0.539 & 0.003 & 5.284 & -0.566 & 1.432 & 5.227 & -1.045 & 0.903 \\
\hline HTZ2 & -1.770 & -8.477 & 0.000 & 4.055 & -1.438 & 2.877 & 4.388 & -1.665 & 1.170 & 4.100 & -0.546 & 3.017 & 4.563 & -0.976 & 1.266 \\
\hline HTZ3 & 4.649 & -5.870 & 0.148 & 5.104 & -0.861 & 3.922 & 4.243 & -1.539 & 1.933 & 5.304 & -1.370 & 1.398 & 5.138 & -1.217 & 1.930 \\
\hline HTZ4 & -3.169 & $\begin{array}{c}- \\
12.002\end{array}$ & 0.482 & 4.173 & -1.898 & 1.864 & 4.654 & -1.627 & 1.128 & 5.163 & -0.745 & 1.304 & 5.084 & -1.143 & 1.018 \\
\hline HTZ5 & 4.021 & 12.325 & 0.246 & 3.215 & -1.481 & 4.232 & 3.256 & -6.374 & 2.317 & 2.382 & -5.263 & 1.238 & 4.623 & -0.951 & 1.280 \\
\hline HTZ6 & 6.605 & -3.866 & 1.6487 & 4.004 & -1.104 & 2.851 & 5.834 & -1.310 & 3.111 & 5.286 & -1.530 & 1.436 & 6.336 & -2.326 & 3.781 \\
\hline HTZ7 & 4.977 & -5.434 & 0.655 & 5.197 & -2.040 & 3.250 & 5.352 & -1.371 & 1.172 & 6.138 & -1.734 & 1.627 & 4.908 & -1.057 & 1.335 \\
\hline HTZ8 & 1.025 & -8.223 & 0.000 & 3.549 & -1.310 & 2.403 & 4.024 & -3.825 & 2.440 & 4.980 & -0.593 & 1.474 & 5.164 & -1.291 & 0.999 \\
\hline HTZ9 & 3.386 & -7.041 & 0.194 & 5.567 & -1.622 & 3.057 & 6.792 & -2.581 & 1.088 & 5.794 & -0.683 & 1.774 & 6.053 & -1.408 & 1.037 \\
\hline HTZ10 & 4.744 & -5.463 & 0.837 & 4.520 & -2.469 & 3 & 7.758 & -1.518 & 3.765 & 5.345 & -1.133 & 3.661 & 7.507 & -2.080 & 4.086 \\
\hline HTZ11 & 2.991 & -6.177 & 0 & 3.453 & -0.721 & 1.266 & 4.841 & -1.738 & 0.045 & 4.368 & -0.805 & 1.074 & 6.176 & -1.380 & 1.511 \\
\hline HTZ12 & 4.810 & -6.157 & 0.275 & 5.296 & -2.814 & 3.605 & 5.138 & -1.840 & 2.189 & 5.083 & -0.870 & 1.536 & 5.592 & -1.321 & 1.525 \\
\hline HTZ13 & 4.868 & -3.837 & 0 & 4.863 & -0.535 & 2.405 & 4.656 & -0.681 & 3.152 & 4.246 & -2.335 & 0.529 & 6.404 & -0.975 & 2.954 \\
\hline HTZ14 & 5.646 & -3.473 & 0 & 4.948 & -0.801 & 2.324 & 4.953 & -1.672 & 1.066 & 5.058 & -1.174 & 1.121 & 5.114 & -1.299 & 1.296 \\
\hline HTZ15 & 3.428 & -4.957 & 0.348 & 3.949 & -0.614 & 1.873 & 4.049 & -0.787 & 1.224 & 4.796 & -1.066 & 1.489 & 3.510 & -0.607 & 0.461 \\
\hline HTZ16 & 4.227 & -4.787 & 0.298 & 4.654 & -1.534 & 2.096 & 6.143 & -1.204 & 2.879 & 4.854 & -0.994 & 1.564 & 7.102 & -0.917 & 3.001 \\
\hline HTZ17 & 3.784 & -5.018 & 0.380 & 3.661 & -0.897 & 1.676 & 4.016 & -1.179 & 1.384 & 4.039 & -0.569 & 2.706 & 4.256 & -1.040 & 1.236 \\
\hline $\begin{array}{l}\text { HTZ } \\
\text { STD } \\
\end{array}$ & 4.722 & -1.084 & 1.063 & 3.319 & -0.890 & 3.033 & 3.564 & -0.272 & 2.367 & 3.394 & -0.882 & 1.169 & 4.237 & -0.801 & 1.855 \\
\hline
\end{tabular}

